Prepared for the U.S. Department of Energy

under Contract DE-AC05-76RL01830

\title{
Y-12 National Security Complex Water Assessment
}

\author{
E Elam \\ KL McMordie Stoughton \\ $P$ Bassett
}

November 2010

Pacific Northwest

NATIONAL LABORATORY

Proudly Operated by Battelle Since 1965 


\title{
DISCLAIMER
}

United States Government. Neither the United States Government nor any agency thereof, nor Battelle Memorial Institute, nor any of their employees, makes any warranty, express or implied, or assumes any legal liability or responsibility for the accuracy, completeness, or usefulness of any information, apparatus, product, or process disclosed, or represents that its use would not infringe privately owned rights. Reference herein to any specific commercial product, process, or service by trade name, trademark, manufacturer, or otherwise does not necessarily constitute or imply its endorsement, recommendation, or favoring by the United States Government or any agency thereof, or Battelle Memorial Institute. The views and opinions of authors expressed herein do not necessarily state or reflect those of the United States Government or any agency thereof.

\author{
PACIFIC NORTHWEST NATIONAL LABORATORY \\ operated by \\ BATTELLE \\ for the \\ UNITED STATES DEPARTMENT OF ENERGY \\ under Contract DE-AC05-76RL01830 \\ Printed in the United States of America \\ Available to DOE and DOE contractors from the \\ Office of Scientific and Technical Information, \\ P.O. Box 62, Oak Ridge, TN 37831-0062; \\ ph: (865) 576-8401, fax: (865) 576-5728 \\ email: reports@adonis.osti.gov \\ Available to the public from the National Technical Information Service, \\ U.S. Department of Commerce, 5285 Port Royal Rd., Springfield, VA 22161 \\ ph: (800) 553-6847, fax: (703) 605-6900 \\ email: orders@ntis.fedworld.gov \\ online ordering: http://www.ntis.gov/ordering.htm
}

This document was printed on recycled paper.

$(8 / 00)$ 
PNNL-19919

\title{
Y-12 National Security Complex Water Assessment
}

\author{
E Elam $^{(a)}$ \\ $P$ Bassett $^{(a)}$ \\ KL McMordie Stoughton
}

November 2010

Prepared for

Federal Energy Management Program U.S. Department of Energy

under Contract DE-AC05-76RL01830

Pacific Northwest National Laboratory

Richland, Washington 99352

(a) Water Savers, LLC 



\section{Acknowledgments}

This document was prepared by Water Savers, LLC and the Pacific Northwest National Laboratory (PNNL) on behalf of the Federal Energy Management Program. The authors would like to thank the following individuals who provided key support in the development of the water assessment and production of the final report.

Rosanne Smith - Y-12 National Security Complex

Reeshemah Burrell - Y-12 National Security Complex

Al Roberson - Y-12 National Security Complex

Larry Petrowski - Y-12 National Security Complex

Melanie Dillon - Y-12 National Security Complex

Gary Beck - Y-12 National Security Complex

Anthony Dull - DOE NNSA Y-12 Site Office

William Lintner - Department of Energy Federal Energy Management Program

Brian Boyd- Pacific Northwest National Laboratory

Shannon Colson - Pacific Northwest National Laboratory

Elisabeth Giever - Pacific Northwest National Laboratory

Dave Payson - Pacific Northwest National Laboratory

Michael Parker - Pacific Northwest National Laboratory

Bill Sandusky - Pacific Northwest National Laboratory

The authors of the report were:

Eric Elam - Water Savers, LLC

Paul Bassett - Water Savers, LLC

Kate McMordie Stoughton - Pacific Northwest National Laboratory 



\section{Acronyms and Abbreviations}

\begin{tabular}{|c|c|}
\hline AIP & Annual Inspections Program \\
\hline Btu & British Thermal Units \\
\hline $\mathrm{COC}$ & Cycles of Concentration \\
\hline DOE & U.S. Department of Energy \\
\hline DHW & domestic hot water \\
\hline $\mathrm{DX}$ & direct expansion \\
\hline E.O. & Executive Order \\
\hline EDI & electro-deionizer \\
\hline EISA & Energy Independence and Security Act \\
\hline EPA & U.S. Environmental Protection Agency \\
\hline ESPC & energy savings performance contract \\
\hline FEMP & Federal Energy Management Program \\
\hline FTUPD & female toilet usage per day \\
\hline FUPD & fixture usage per day \\
\hline FY & fiscal year \\
\hline $\mathrm{gal} / \mathrm{yr}$ & gallons per year \\
\hline gpf & gallons per flush \\
\hline gpm & gallons per minute \\
\hline HET & high efficiency toilets \\
\hline HEU & high efficiency urinals \\
\hline HEUMF & Highly Enriched Uranium Materials Facility \\
\hline HVAC & heating, ventilating and air conditioning \\
\hline JCC & Jack Case Center \\
\hline kgal & thousand gallons \\
\hline KUPD & kitchen/lab faucet usage per day \\
\hline LUPD & lavatory usage per day \\
\hline Mlbs/hr & thousand pounds per hour \\
\hline MMBtu & million British Thermal Units \\
\hline MTUPD & male toilet usage per day \\
\hline NPDES & National Pollutant Discharge Elimination System \\
\hline O\&M & operations and maintenance \\
\hline PNNL & Pacific Northwest National Laboratory \\
\hline ppm & parts per million \\
\hline
\end{tabular}


RO reverse osmosis

SUPD shower usage per day

SWHISS surface water hydrological information support system

TAMP Total Accountability and Management Plan

TDS total dissolved solids

WCAP

Water Conservation Awareness Program

WCM

water conservation measure

$\mathrm{Y}-12$

Y-12 National Security Complex 


\section{Contents}

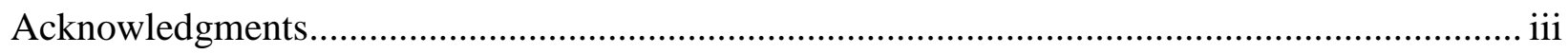

Acronyms and Abbreviations .................................................................................................

Chapter 1 Executive Summary ……………………............................................................1.1

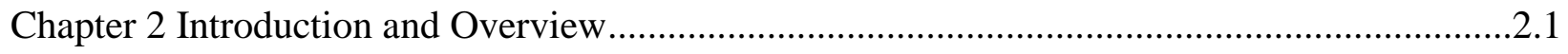

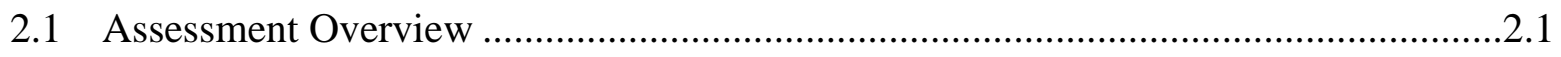

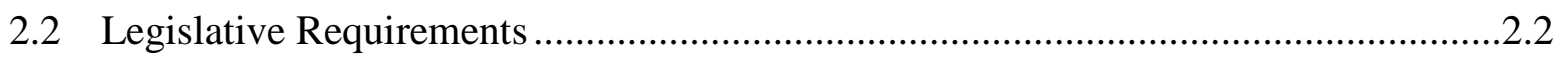

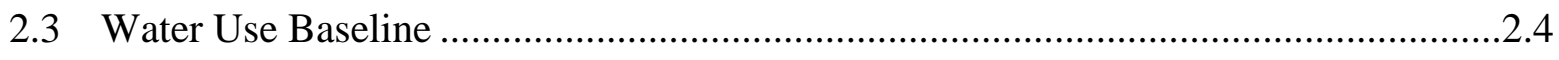

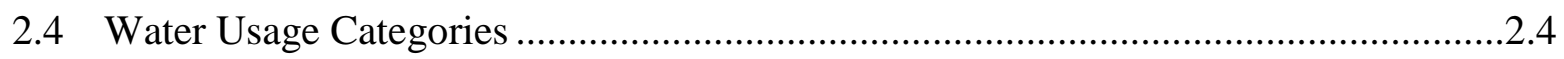

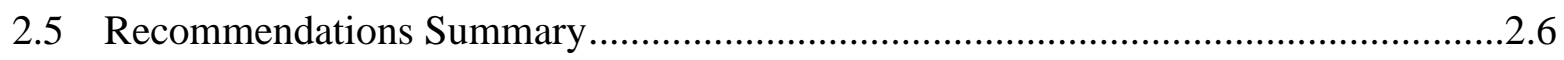

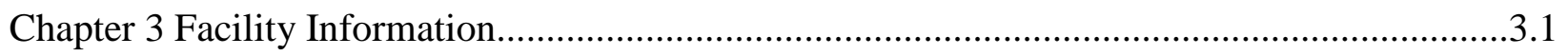

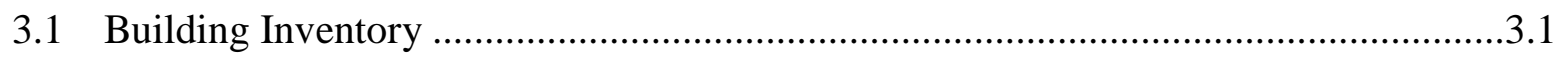

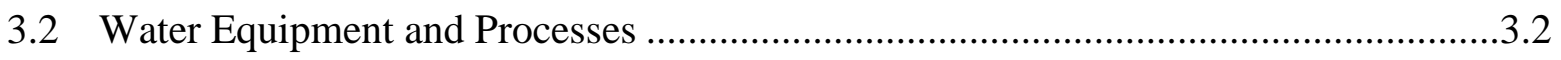

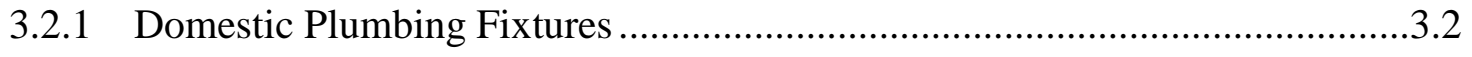

3.2.2 Commercial Kitchen Equipment ......................................................................

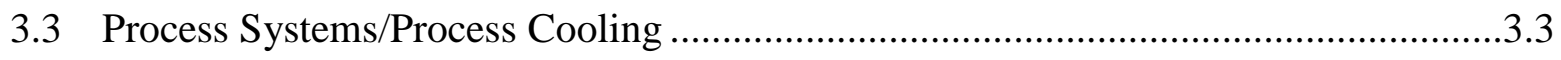

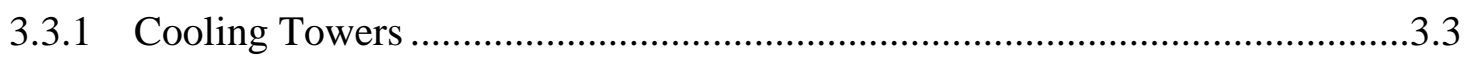

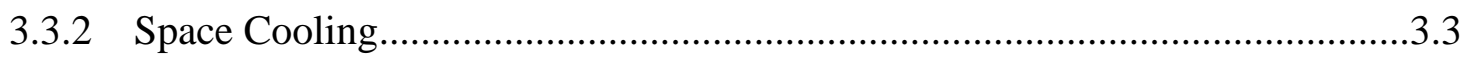

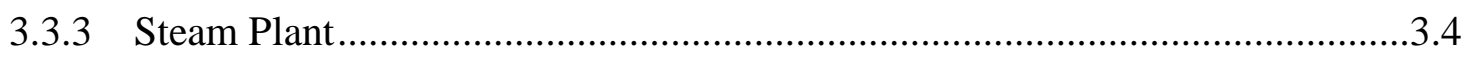

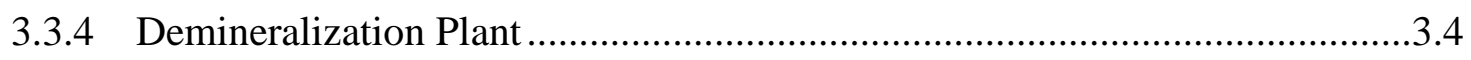

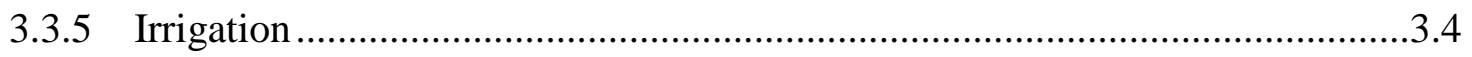

3.3.6 Miscellaneous and Unaccounted Usage ................................................................

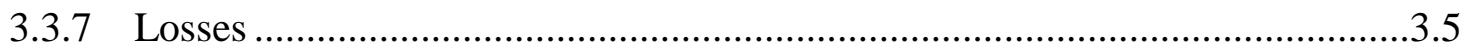

Chapter 4 Water Utility Information.......................................................................................

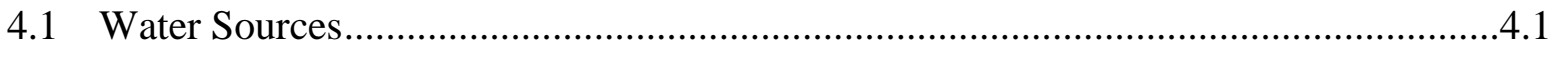

4.1.1 Potable Water Supply ...................................................................................

4.1.2 Augmentation Water ...............................................................................

4.1.3 Stormwater/Groundwater .........................................................................

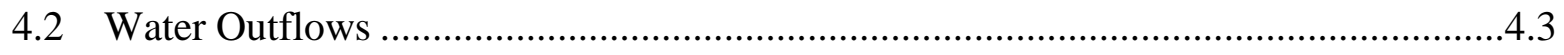

4.2.1 Sanitary Sewer Discharge …………………................................................

4.2.2 East Fork Poplar Creek Stormwater Discharge.................................................4.4

Chapter 5 Water Efficiency Opportunities …………….............................................................5.1 


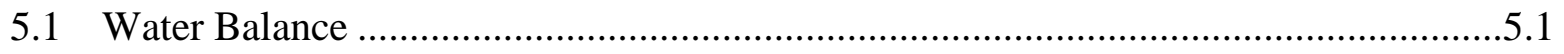

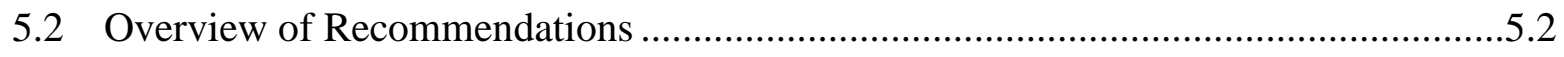

5.3 Domestic Plumbing Fixtures .....................................................................................

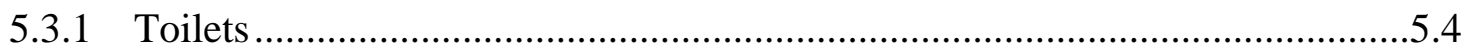

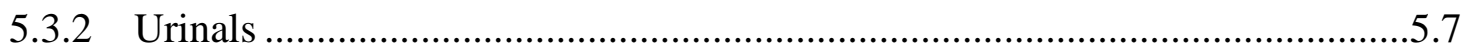

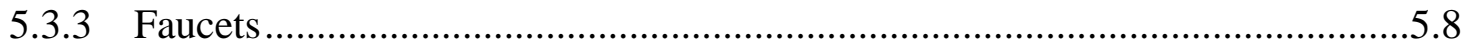

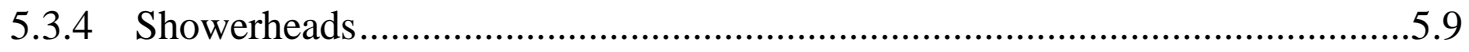

5.4 Commercial Kitchen Water-Using Equipment ......................................................11

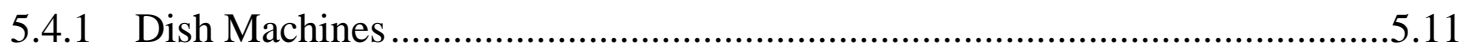

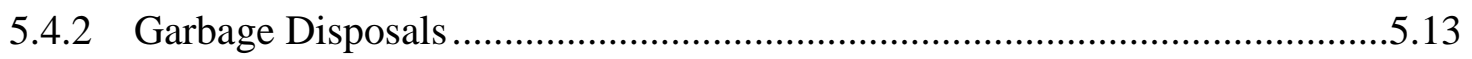

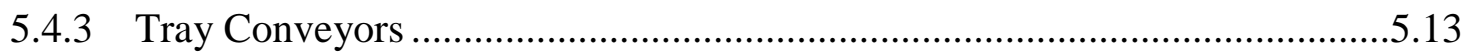

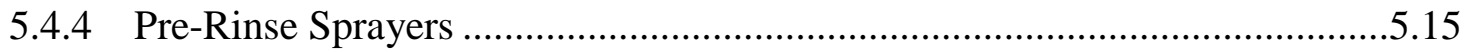

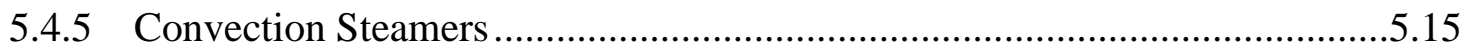

5.4.6 Steam Kettles............................................................................................17

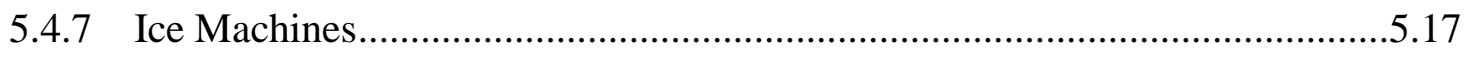

5.4.8 Miscellaneous Kitchen Usage .....................................................................18

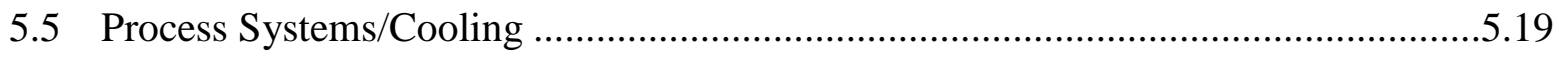

5.5.1 Process Cooling - Closed Chilled Loop.......................................................5.19

5.5.2 Process Cooling - Recycling Condenser Loop ..............................................5.20

5.5.3 Once-through Potable Process Water …………...................................................22

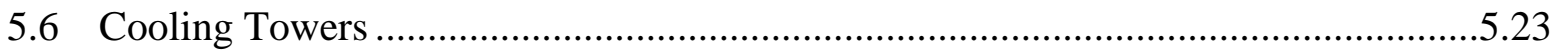

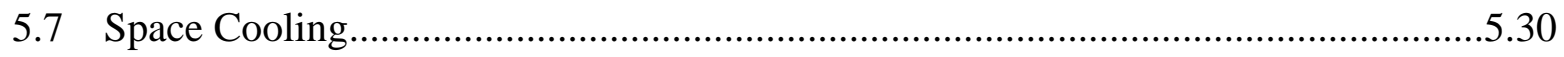

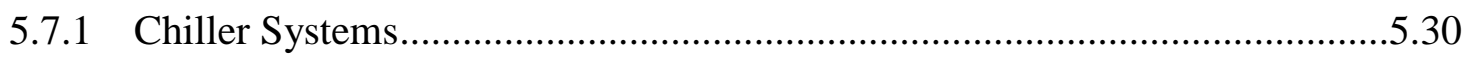

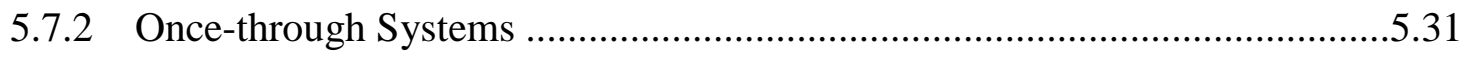

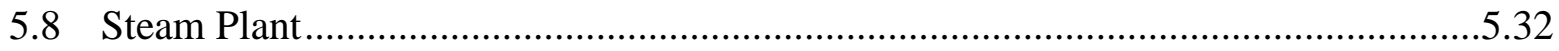

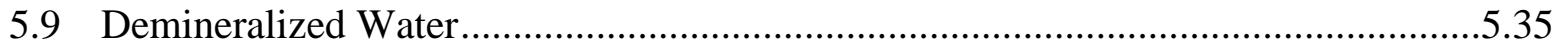

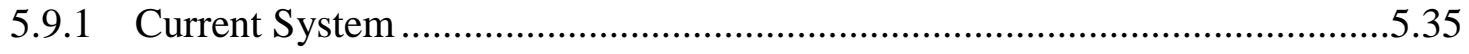

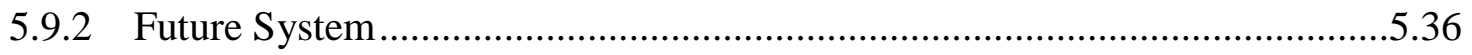

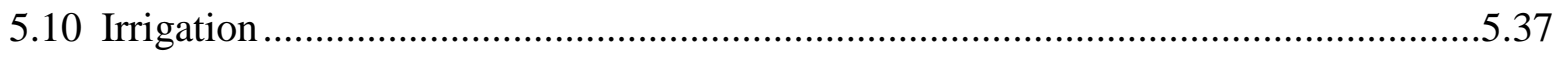

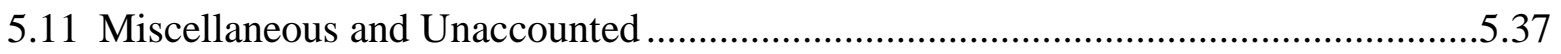

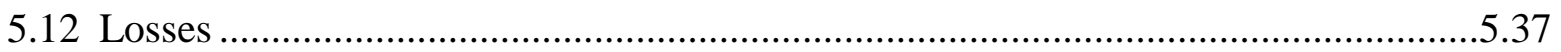

5.13 Operations and Maintenance Recommendations ………............................................5.37

Appendix A Assessment Methodology ………………...........................................................1

Appendix B FY2007 Adjusted Baseline Methodology ......................................................................

Appendix C Sample Water Audit Checklists............................................................................... 


\section{Tables}

Table 1.1. Water Efficiency Recommendations Overview .................................................1.1

Table 4.1. Historical Potable Water Consumption Data at Y-12 ...........................................4.1

Table 5.1. Water Efficiency Recommendations .................................................................5.3

Table 5.2. Domestic Plumbing Cost and Savings Summary ................................................5.4

Table 5.3. Toilet Cost and Savings Detail .............................................................................

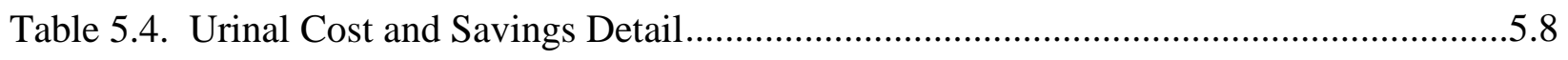

Table 5.5. Faucets Cost and Savings Detail.........................................................................

Table 5.6. Showerhead Cost and Savings Detail ..............................................................5.10

Table 5.7. Kitchen Equipment Cost and Savings Summary ................................................5.11

Table 5.8. Dish Machine Cost and Savings Detail .............................................................5.12

Table 5.9. Garbage Disposal Cost and Savings Detail .......................................................5.13

Table 5.10. Tray Conveyor Cost and Savings Detail..........................................................5.14

Table 5.11. Pre-Rinse Sprayers Cost and Savings Detail .....................................................5.15

Table 5.12. Steamer Cost and Savings Detail....................................................................5.16

Table 5.13. Ice Machine Cost and Savings Detail ...............................................................5.18

Table 5.14. Process Cooling Cost and Savings Summary ....................................................5.19

Table 5.15. Condenser Loop Repairs Cost and Savings Detail ............................................5.22

Table 5.16. Cooling Tower Upgrades Cost and Savings Summary .........................................5.25

Table 5.17. Cooling Tower Upgrades Cost and Savings Detail ............................................5.30

Table 5.18. Space Cooling Cost and Savings Summary.......................................................5.30

Table 5.19. Space Cooling Upgrades Cost and Savings Detail .............................................5.32

Table 5.20. Steam Plant Upgrades Cost and Savings Summary .............................................5.32

Table 5.21. Steam Plant Upgrades Cost and Savings Detail .................................................5.35 


\section{Figures}

Figure 2.1. Y-12 Water End-Use Breakout ....................................................................2.5

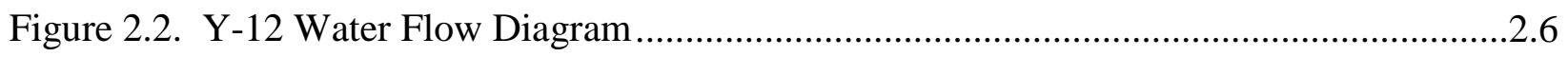

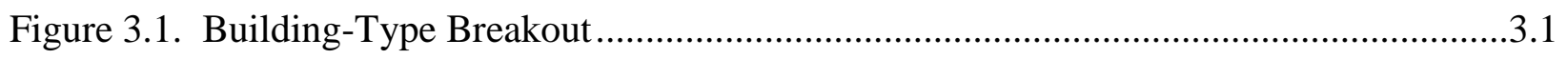

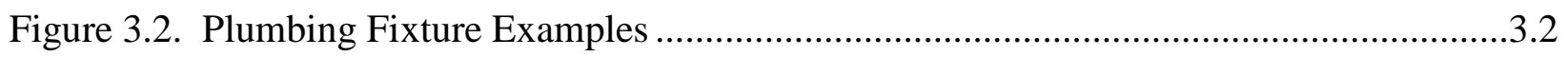

Figure 3.3. Commercial Kitchen Equipment Examples .......................................................2

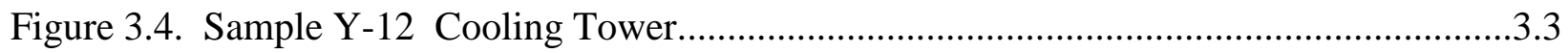

Figure 4.1. Historical Potable Water Consumption Plot at Y-12 ..........................................4.2

Figure 4.2. Augmentation Water Supply at the Head Waters of the East Fork Poplar

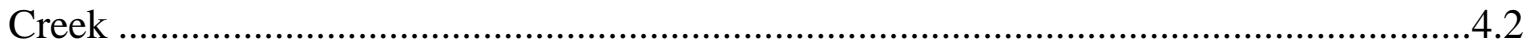

Figure 4.3. Groundwater Infiltration into Building Crawl Spaces.........................................4.3

Figure 4.4. Correlation between Rain Events and Sanitary Sewer Flow Rates at Y-12 .............4.5

Figure 5.1. Y-12 Water Flow Diagram .............................................................................

Figure 5.2. Water Balance Chart for Major Use Categories.....................................................2

Figure 5.3. Piston Valve Schematic ...................................................................................5.5

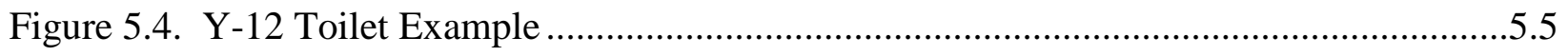

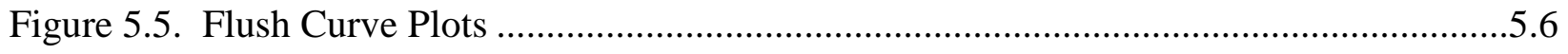

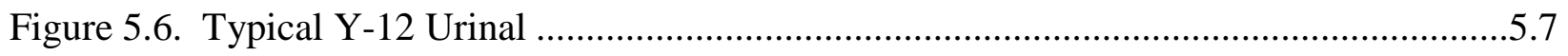

Figure 5.7. Typical Y-12 Lavatory Faucet........................................................................5.8

Figure 5.8. Typical Change House Showerhead...................................................................5.10

Figure 5.9. Jack Case Center Dish Machine .......................................................................5.12

Figure 5.10. Jack Case Center Tray Conveyor System Discharge Location ............................5.14

Figure 5.11. Typical Pre-rinse Sprayer Head in the JCC Kitchen ..........................................5.15

Figure 5.12. Maximicer Installation Schematic ..............................................................5.17

Figure 5.13. Condenser Loop Supply and Return Flow Rate Discrepancy .............................5.21

Figure 5.14. 9409-18 Cooling Tower with Constant Flow Bypass .........................................5.27

Figure 5.15. Typical Water-Cooled Air Conditioning Unit and Dechlorination Box ...............5.31

B.1 Linear Extrapolation of Historic Potable Water Use..................................................2 


\section{Chapter 1 Executive Summary}

The Federal Energy Management Program (FEMP) sponsored a water assessment at the Y-12 National Security Complex (Y-12) located in Oak Ridge, Tennessee. Driven by mandated water reduction goals of Executive Orders 13423 and 13514, the objective of the water assessment is to develop a comprehensive understanding of the current water-consuming applications and equipment at Y-12 and to identify key areas for water efficiency improvements that could be applied not only at Y-12 but at other Federal facilities as well.

FEMP selected Pacific Northwest National Laboratory (PNNL) to coordinate and manage the water assessment. PNNL contracted Water Savers, LLC to lead the technical aspects of the water assessment. Water Savers provided key technical expertise in water auditing, metering, and cooling systems.

Many of the systems at Y-12 presented opportunities for water efficiency improvements. Overall, a total reduction in water consumption of $228,154 \mathrm{kgal} / \mathrm{yr}$ can be achieved if all the water conservation measures recommended in this report are implemented. This is approximately a $16.5 \%$ reduction in overall potable water consumption. In addition, the recommended measures will also yield an energy reduction of 40,307 million British Thermal Units (MMBtu) per year. If all measures are implemented, a total annual utility cost reduction of $\$ 714,201$ can be achieved. Table 1.1 provides an overview list of water conservation recommendations. It should be noted that the water conservation measure for single pass cooling replacements yielded a negative payback because the measure causes an increase in energy use, which is shown in red font on Table 1.1.

Table 1.1. Water Efficiency Recommendations Overview

\begin{tabular}{|c|c|c|c|c|c|c|c|c|}
\hline WCM \# & WCM Description & \begin{tabular}{|c|} 
Est. Total \\
Water / Sewer \\
Savings \\
(gal/yr)
\end{tabular} & $\begin{array}{c}\text { Est. Total } \\
\text { Water / } \\
\text { Sewer } \\
\text { Savings } \\
\text { (\$\$/yr) }\end{array}$ & $\begin{array}{l}\text { Est. Total } \\
\text { Energy } \\
\text { Savings } \\
\text { (kbtu/yr) }\end{array}$ & $\begin{array}{l}\text { Est. Total } \\
\text { Energy } \\
\text { Savings } \\
\text { (\$\$/yr) }\end{array}$ & $\begin{array}{c}\text { Est. Total } \\
\text { Annual } \\
\text { Savings } \\
\text { (\$\$/yr) }\end{array}$ & $\begin{array}{c}\text { Est. Total } \\
\text { Installed Cost } \\
\text { (\$\$) }\end{array}$ & $\begin{array}{c}\text { Overall } \\
\text { Simple } \\
\text { Payback } \\
\text { (yrs) }\end{array}$ \\
\hline 1 & Domestic Plumbing Retrofits & $25,383,800$ & $\$ 271,607$ & $4,307,378$ & $\$ 30,996$ & $\$ 302,603$ & $\$ 907,593$ & 3.00 \\
\hline 2 & Kitchen Equipment Upgrades & $1,363,149$ & $\$ 14,586$ & 464,364 & $\$ 16,112$ & $\$ 30,698$ & $\$ 158,388$ & 5.16 \\
\hline 3 & \begin{tabular}{|l} 
Process System Upgrades \\
(Condenser Loop Repairs)
\end{tabular} & $57,738,123$ & $\$ 76,214$ & 0 & $\$ 0$ & $\$ 76,214$ & $\$ 336,000$ & 4.41 \\
\hline 4 & Cooling Tower Upgrades & $71,964,002$ & $\$ 94,992$ & $9,250,645$ & $\$ 145,956$ & $\$ 240,948$ & $\$ 2,881,120$ & 11.96 \\
\hline 5 & Single Pass Cooling Replacements & $23,220,432$ & $\$ 30,651$ & $(18,184,464)$ & $(\$ 286,913)$ & $(\$ 256,262)$ & $\$ 2,892,857$ & $\begin{array}{l}\text { Not Cost } \\
\text { Effective }\end{array}$ \\
\hline 6 & Steam Plant Upgrades & $48,484,848$ & $\$ 64,000$ & $44,468,745$ & $\$ 256,000$ & $\$ 320,000$ & $\$ 4,544,898$ & 14.20 \\
\hline & Assessment Summary TOTAL & $228,154,354$ & $\$ 552,050$ & $40,306,668$ & $\$ 162,151$ & $\$ 714,201$ & $\$ 11,720,856$ & 16.41 \\
\hline
\end{tabular}





\section{Chapter 2 Introduction and Overview}

\subsection{Assessment Overview}

The Y-12 National Security Complex (Y-12) was selected for a water assessment by the Federal Energy Management Program (FEMP) because of the large potential for Y-12's water reduction. Y-12 is one of the U.S. Department of Energy's (DOE's) largest water users, consuming more than 1.3 billion gallons of potable water annually. Y-12 also has large cooling loads with multiple single-pass cooling applications. Therefore, the potential for water savings at $\mathrm{Y}-12$ is tremendous.

Y-12 occupies over 5 million square feet of building space, housing over 6,700 staff members and ancillary contractors onsite. Y-12 purchases potable water from the City of Oak Ridge, consuming over 1 billion gallons each year in buildings, equipment, and processes. In addition, Y-12 purchases over 1.5 billion gallons of non-potable water annually, which augments the site's storm sewer flow so that the complex can meet the minimum discharge requirements. This non-potable water is not considered a "water use” by Y-12 because it is not utilized in any process or building at the complex. This augmentation water is not included in water-use reporting for $\mathrm{Y}-12$.

FEMP's proactive strategy centers on identifying large users and pinpointing sites that need assistance in developing a sound water management plan so as to create a large impact across the entire agency. In addition, FEMP aims at developing "lessons learned" from the Y-12 water assessment to "cross-pollinate” successful water management technologies and techniques to other large manufacturing-oriented DOE sites.

FEMP selected Pacific Northwest National Laboratory (PNNL) to coordinate and manage the water assessment. PNNL contracted Water Savers, LLC to lead the technical aspects of the water assessment. Water Savers provided key technical expertise in water auditing, metering, and cooling systems.

The objective of the water assessment at Y-12 was to develop a comprehensive understanding of the current water use at the complex. To this end, the water-assessment team first reviewed and analyzed several years' worth of water-use data and reviewed building inventory data. Next, the team completed five site visits at Y-12 that included interviewing Y-12 staff, thorough walkthrough facility audits, and spot metering key applications. Next, the team compiled data from the site visits to develop a water balance of $\mathrm{Y}-12$, revealing the largest water consumers at the site. Then, efficiency opportunities were investigated based on key observations made during the site visits. Finally, all the data was pulled together to develop a comprehensive set of water efficiency recommendations with economic analysis. 
This four-phased approach is shown in more detail in the following steps:

\section{Prepare Assessment}

- Set goals of assessment

- Gather and analyze historic water data

- Collect building inventory data and prioritize buildings for audits

- Conduct initial meeting with key personnel to develop plan of action

\section{Conduct Water Audits}

- Perform walkthrough of priority buildings

- Perform detailed assessments of cooling systems

- Meter key water uses

- Work with staff to collect necessary data from secure buildings

\section{Evaluate Efficiency Opportunities - investigate water measures in the following areas}

- Domestic plumbing

- Commercial kitchen

- Process systems

- Cooling towers

- Single-pass cooling

- Steam systems

\section{Compile Results}

- Estimate water savings of water measures

- Develop economics of water measures

- Recommend key measures based on results

- Identify "lessons learned" to disseminate to other DOE sites

\subsection{Legislative Requirements}

Federal laws and regulations require Federal agencies to reduce water use and improve water efficiency. Each Federal agency is responsible for meeting these goals as a whole and each individual site within the agency should strive to meet or even exceed these goals. One of the goals of the water assessment is targeted to help Y-12 meet the legislative requirements related to water reduction.

The current key Federal requirements related to water are:

- Executive Order 13423

- Executive Order 13514

- Energy Independence and Security Act of 2007 
Executive Order 13423: Executive Order (E.O.) 13423 requires Federal agencies to reduce water consumption intensity (gallons per square foot) $2 \%$ annually through the end of fiscal year 2015, or $16 \%$ by the end of fiscal year 2015 from a 2007 baseline. This requirement is to be achieved incrementally by fiscal year beginning in 2008.

E.O. 13423 also directs Federal facilities to conduct annual water audits of at least $10 \%$ of facility square footage and to conduct audits at least every 10 years. Federal agencies also should purchase water efficient products and services, including WaterSense-labeled products, ${ }^{1}$ and use contractors who are certified through a WaterSense-labeled program where applicable.

Executive Order 13514: E.O. 13514 expands the water efficiency requirements of E.O. 13423. E.O. 13514 requires that Federal agencies improve water efficiency and management by:

- Reducing potable water consumption intensity $2 \%$ annually through fiscal year 2020 , or $26 \%$ by the end of fiscal year 2020, relative to a fiscal year 2007 baseline. (This is an expansion of the water requirements within E.O. 13423.)

- Reducing agency industrial, landscaping, and agricultural water consumption 2\% annually, or $20 \%$ by the end of fiscal year 2020, relative to a fiscal year 2010 baseline.

- Identifying, promoting, and implementing water-reuse strategies consistent with state law that reduce potable water consumption.

- Implementing and achieving objectives identified in the stormwater management guidance issued by the Environmental Protection Agency (EPA). ${ }^{2}$

Energy Independence and Security Act of 2007: The Energy Independence and Security Act (EISA) of 2007 requires that each Federal agency identifies all covered facilities that constitute at least $75 \%$ of the agency's facility energy and water use. ${ }^{3}$ Comprehensive energy and water evaluations must be conducted for $25 \%$ of covered facilities annually so that an evaluation of each facility is completed at least once every four years. As part of these evaluations, energy and water efficiency measures must be identified.

The water assessment conducted at $\mathrm{Y}-12$ helps to meet the some of the Federal requirements through the following tasks:

- Evaluation of water-use baselines related to E.O. 13423 and E.O. 13514

- Comprehensive water facility evaluations per requirements of E.O. 13423 and EISA

\footnotetext{
${ }^{1}$ WaterSense is a program through the Environmental Protection Agency that provides independent testing and labeling of water efficient products to help consumers identify water saving and high performing fixtures. Get more information at: http://www.epa.gov/watersense

${ }^{2}$ More information on EPA stormwater guidance is available on the EPA Web site: http://www.epa.gov/owow/nps/lid/section438/

${ }^{3}$ A covered facility may be defined as "a group of facilities at a single location or multiple locations managed as an integrated operation." An energy manager must be designated for each of these covered facilities.
} 
- Identification of water savings measures that meet EISA requirements and upon implementation will help to reduce water use per requirements of E.O. 13423 and E.O. 13514

\subsection{Water Use Baseline}

During analysis of historical potable water consumption for $\mathrm{Y}-12$, it was discovered that fiscal year (FY) 2007 metered water consumption was uncharacteristically low due to failed water meters. Near the beginning of FY2008, the City of Oak Ridge replaced all water meters tracking consumption supplied to Y-12. Subsequently the following year, recorded water consumption increased by $41 \%$. For the purposes of the water assessment, a baseline was determined by taking a 7-year historical average (FY2003 - FY2010), excluding the FY2007 faulty meter year. This methodology yields an average annual consumption of 1.38 billion gallons. This 7-year historic baseline was used for the analysis of the assessment as a basis for water and cost savings.

Through the process of examining the historic water-use data and uncovering the issues related to the erroneous FY2007 data, a new FY2007 potable water-use baseline was developed for the purposes of tracking water reduction per the requirements of Executive Orders 13423 and 13514. (See Section 2.2 for more information on Federal water reduction requirements.) The new FY2007 baseline is estimated to be 1.37 billion gallons. This estimate was calculated by developing a linear regression of the water-use data prior and subsequent to the failed meter and extrapolating the data for FY2007. Please refer to Appendix B for details on how the baseline was corrected.

\subsection{Water Usage Categories}

Six primary categories of water usage at Y-12 were determined as a result of this assessment. Ranked by largest to smallest, the primary categories are:

1. Once-through process usage - This category includes both heat dissipation and direct consumptive use and accounts for nearly 34.5\%, or 477,226 thousand gallons per year $(\mathrm{kgal} / \mathrm{yr})$ of the total site water consumption.

2. Cooling tower make-up - This category accounts for $266,533 \mathrm{kgal} / \mathrm{yr}$, or $19.3 \%$ of the total site water consumption.

3. Steam plant consumption - This category accounts for $203,121 \mathrm{kgal} / \mathrm{yr}$, or $14.7 \%$ of the total site water consumption.

4. Demineralized water - This category accounts for $72,793 \mathrm{kgal} / \mathrm{yr}$, or $5.3 \%$ of the total site water consumption.

5. Domestic usage - This category includes all domestic plumbing, kitchen, ice machine, and janitorial usage onsite and accounts for $49,833 \mathrm{kgal} / \mathrm{yr}$, or $3.6 \%$ of the total site water consumption. 
6. Once-through space cooling - This category accounts for $23,220 \mathrm{kgal} / \mathrm{yr}$, or $1.7 \%$ of the total site water consumption.

Additional secondary categories of water consumption at $\mathrm{Y}-12$ were also determined during this assessment. Irrigation consumption at Y-12 accounts for less than $0.5 \%$ of total site water consumption. This is due to few areas with supplemental irrigation and minimal operation of the systems throughout the year. Approximately 4\% of the adjusted baseline consumption has been assigned to distribution system leaks. This percentage is not uncommon for distribution systems greater than 50 years old. The majority of system leakage will go unnoticed due to small pinhole leaks (1.0 gallons per minute [gpm] or less) that never present evidence of leakage. In fact, it would only take 105 of these tiny leaks to account for this system loss. Lastly, $16.9 \%$ of the total baseline consumption has been categorized into a miscellaneous and unaccounted usage group. This category primarily accounts for various water consumptions that cannot be accurately calculated due to the complexity of $\mathrm{Y}-12$ water uses as well as the fact the water assessment team did not have full access to all of the water-using equipment onsite. The miscellaneous and unaccounted water category also establishes conservative estimates in water use and savings calculations. Figure 2.1 illustrates the categorical separation of water use at Y-12.

Figure 2.2 illustrates the water flow balance of all categories of water supply and use at Y-12. Estimated consumption values for each category have been assigned based on results from the onsite inspection. Categories are discussed in greater detail in Chapter 5 of this assessment document.

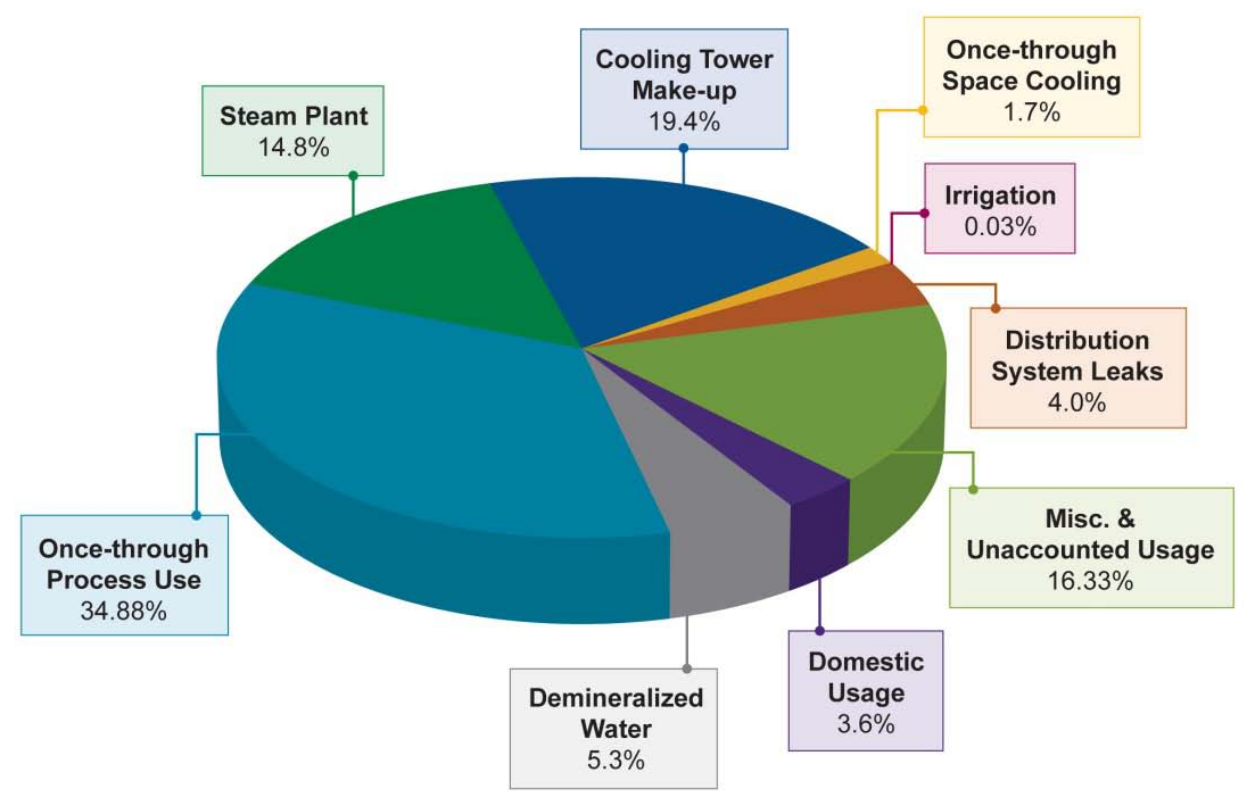

Figure 2.1. Y-12 Water End-Use Breakout 


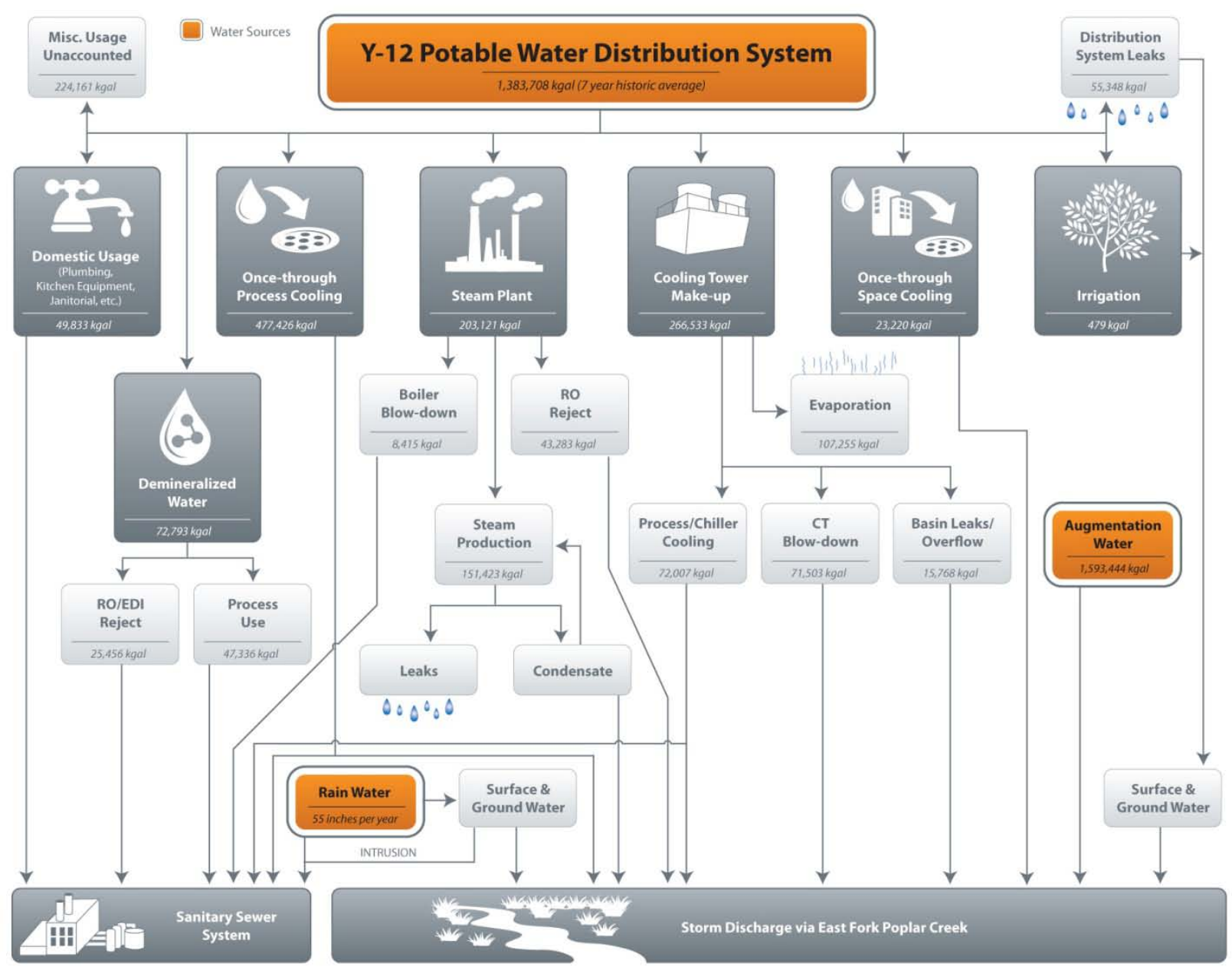

Figure 2.2. Y-12 Water Flow Diagram

\subsection{Recommendations Summary}

Many of the systems at Y-12 presented opportunities for water efficiency improvements. Overall, a total reduction in water consumption of 228,154 kgal/yr can be achieved if all measures are implemented. This is approximately a $16.5 \%$ reduction in overall potable water consumption. In addition, the recommended measures will also yield an energy reduction of 40,307 million British Thermal Units (MMBtu) per year. If all measures are implemented, a total annual utility cost reduction of $\$ 714,201$ can be achieved. A summary of major recommendations is as follows:

1. Domestic Plumbing Retrofits/Replacements - These measures include installation of high efficiency toilets (HET), high efficiency urinals (HEU), high efficiency faucets/faucet restrictors, and water efficient showerheads. These measures yield a water consumption savings of 25,384 kgal/yr and an energy consumption savings of 4,307 MMBtu/yr. This equates to an annual utility cost savings of $\$ 302,603$. Measures of this nature require an initial investment of $\$ 907,593$, providing a 3.00-year payback. An additional direct 
maintenance cost reduction of $\$ 7,096$ annually is achieved due to replacement of diaphragmtype valves with piston technology and replacement of flapper-style toilets with pressure vessel units. (Detailed information on operation and maintenance of piston versus diaphragm valves can be found in Section 5.3 of this document.)

2. Kitchen Equipment Upgrades - These measures include the following installations:

a. High efficiency dish machine with technology that stores and recycles the rinse water for the next wash cycle

b. Flow restriction for garbage disposal supply

c. Flow restriction and controls for tray conveyor systems

d. High efficiency sprayers

e. High efficiency connectionless steamers

f. Replacement of existing water-cooled ice machines with air-cooled equivalents,

g. Counter-flow heat exchangers on all existing and proposed air-cooled ice machines.

These measures yield a water consumption savings of 1,363 kgal/yr and an energy consumption savings of $464 \mathrm{MMBtu} / \mathrm{yr}$. This equates to an annual utility cost savings of $\$ 30,698$. Measures of this nature require an initial investment of $\$ 158,388$, providing a simple payback of 5.16 years.

3. Process System Upgrades (Condenser Loop Repairs) - This measure includes repair of any condenser loop connections that do not return condenser water to the cooling towers. Primarily, the faulty connections were identified for systems that are connected to the 940918/31 and 9409-23 cooling towers. This measure can yield a water consumption savings of $57,738 \mathrm{kgal} / \mathrm{yr}$, which equates to an annual utility cost savings of $\$ 76,214$. The initial cost to implement this measure is estimated at $\$ 336,000$, providing a simple payback of 4.41 years. Additional process systems upgrades are discussed in Section 5.5 of this assessment document.

4. Cooling Tower Upgrades - These measures include installation of advanced sub-metering systems, conductivity controllers, and side-stream filtration systems on cooling towers. If fully implemented, these measures will yield a water consumption savings of 71,964 kgal/yr and an energy consumption reduction of 9,250 MMBtu/yr. This equates to a utility cost reduction of \$240,948 annually. Implementation of these measures would require an initial investment of $\$ 2,881,120$, providing a simple payback of 11.96 years. In addition to reduced consumption, measures of this nature provide substantial operations and maintenance savings due to prolonged life of equipment. O\&M savings for these measures have not been calculated for this assessment. O\&M savings, especially labor-related savings, can be difficult to quantify because overhead costs may not change dramatically. But these savings should be examined and if appropriate, taken into consideration upon implementation. 
5. Single-Pass Space Cooling Replacements - This measure includes removal of all single-pass, water-cooled air conditioning systems and replacement with direct expansion (DX) or packaged air-cooled chiller units. Replacements of this nature will yield a water consumption savings of 23,220 kgal/yr, but an energy consumption increase of $18,184 \mathrm{MMBtu} / \mathrm{yr}$. Overall, these measures yield a utility cost increase of \$256,262, thus generating a negative payback. Details of the decreased efficiency are discussed in Section 5.7 of this assessment document. This option should only be considered if reducing water consumption is the primary goal of Y-12. An estimated cost for installation of these measures is $\$ 2,892,857$. It should be noted that the single-pass systems have exceeded their useful life, and site staff have found it difficult to find replacement parts as the systems begin to fail.

6. Steam Plant Upgrades - These measures include installation of advanced sub-metering systems to track steam plant consumption and continuation and extension of condensate recovery. The current Energy Savings Performance Contract (ESPC) has addressed condensate recovery, and this particular project should be expanded to include the remainder of the Y-12 buildings that are not covered in the ESPC. Measures of this nature are estimated to reduce water consumption by $48,485 \mathrm{kgal} / \mathrm{yr}$ and result in an energy consumption reduction of 44,469 MMBtu/yr. This equates to an estimated utility cost reduction of $\$ 320,000$ annually. Based on current ESPC cost calculations, measures of this nature require an estimated initial investment of \$4,544,898, providing a simple payback of 14.20 years.

7. Operation and Maintenance (O\&M) Programs - These measures include implementation of various site programs designed to provide accountability and awareness of water consumption, as well as recommendations for continual preventative maintenance of cooling towers, domestic plumbing fixtures, potable water and steam distribution systems, and process systems that will reduce water consumption. Although none has been attributed at this time, the programs discussed in Section 5.13 can yield additional savings. 


\section{Chapter 3 Facility Information}

\subsection{Building Inventory}

The Y-12 National Security Complex (Y-12) has 360 buildings comprising over 5 million square feet of facility space. Production, manufacturing, and laboratory buildings make up the large majority of the facility space at Y-12, accounting for $64 \%$ of the total square footage. Office buildings represent the second largest group at Y-12, as shown in Figure 3.1. The largest 20 buildings at $\mathrm{Y}-12$ account for $70 \%$ of the total square footage at the complex.

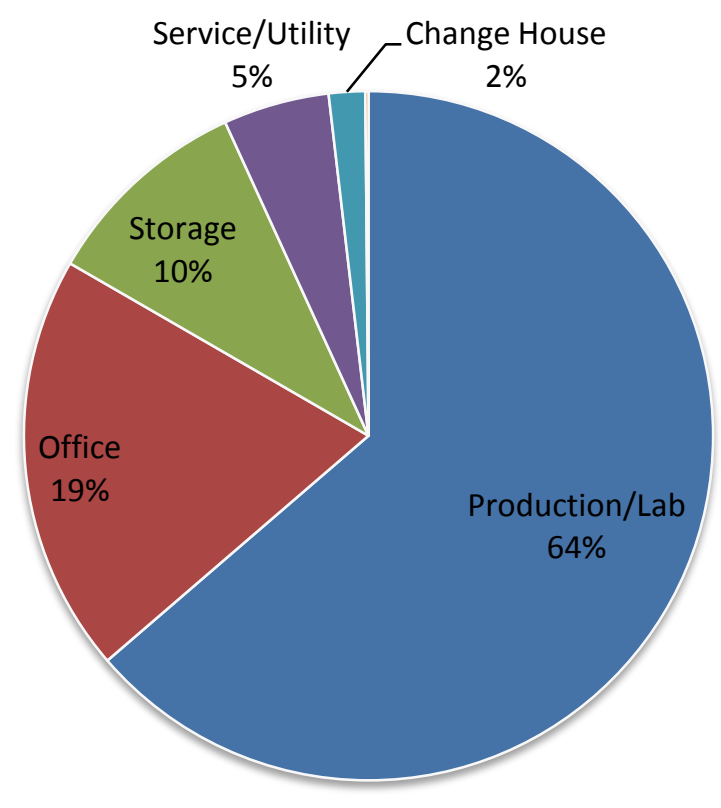

Figure 3.1. Building-Type Breakout

A total of forty-six buildings were physically inspected during the water assessment representing over 1.1 million square feet. For each building surveyed, all major waterconsuming equipment was evaluated. (See next section for a detailed description of waterconsuming equipment.) The water-assessment team surveyed all of Y-12's chiller buildings and associated cooling towers. Fourteen office buildings were surveyed representing nearly 675,000 square feet. All major laboratories and production facilities that were accessible by the team were surveyed as well, totaling over 300,000 square feet. For facilities that were not accessible to the team due to security reasons, Y-12 staff assisted in the collection of necessary data. The water-assessment team trained Y-12 staff on data needed for the survey and provided a checklist to assist in collecting the information. Twenty-three buildings representing 3.4 million square feet were surveyed by Y-12 staff. 


\subsection{Water Equipment and Processes}

Y-12 utilizes a variety of different processes and equipment that consume water. The following topics are discussed in greater detail in Chapter 5 of this assessment document.

\subsubsection{Domestic Plumbing Fixtures}

Domestic plumbing fixtures, including toilets, urinals, faucets, and showerheads use water to carry waste through sanitary sewer lines. New valve and fixture technology, as illustrated in Figure 3.2, presents an opportunity for up to a $65 \%$ reduction in overall water consumption by this category.

Currently at Y-12, domestic plumbing usage accounts for $43,051 \mathrm{kgal}$ per year, or $3.1 \%$ of total site potable water consumption. All water discharged from these fixtures enters the sanitary sewer system, and is subject to sewer treatment charges.

\subsubsection{Commercial Kitchen Equipment}

A variety of different kitchen equipment and processes consume water. Equipment included in this assessment that was identified at Y-12 includes dish machines, tray conveyor systems, garbage disposals, pre-rinse sprayers, convection steamers, steam kettles, and ice machines. It should be noted that ice machines were not only identified in the main kitchen areas, but throughout the facilities as well. Figure 3.3 illustrates examples of high efficiency pre-rinse sprayers and convection steamers.

In addition to equipment-specific usage, general kitchen consumption has to be taken into consideration for a water balance and assessment. Production of meals, general area cleanup, and various other kitchen functions require consumption of water.

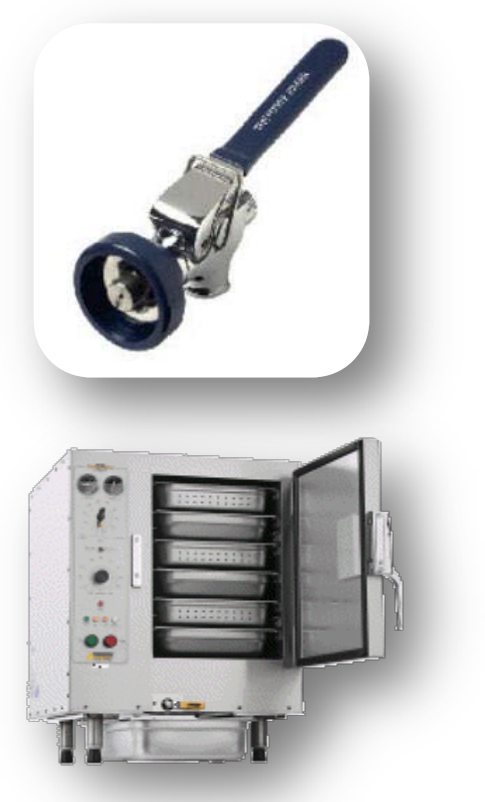

Figure 3.3. Commercial Kitchen Equipment Examples 
Currently at Y-12, kitchen equipment and usage consumption accounts for 4,256 kgal/yr, or $0.31 \%$ of total site potable water consumption. All water discharged from these fixtures or end uses enters the sanitary sewer system, and is subject to sewer treatment charges.

\subsection{Process Systems/Process Cooling}

Y-12 utilizes a wide variety of processes that consume water in its nuclear, manufacturing, and development facilities. Water is used for cooling of process equipment through heat sink methods involving heat exchange, as well as being consumed directly by the process itself. By far, this is the largest category of consumption at Y-12, accounting for over 447,226 kgal/yr, or $35 \%$ of total site potable water consumption. Water discharged from process use and process cooling is directed to both the sanitary sewer system and the storm sewer system. Exact calculations for each discharge cannot be determined at this time.

\subsubsection{Cooling Towers}

Y-12 currently has nine functioning cooling tower systems, similar to what is pictured in Figure 3.4. Cooling towers are a large consumer of water due to evaporation and blow-down required for successful cooling of condenser water. Cooling tower consumption at Y-12 is estimated at $266,533 \mathrm{kgal}$, or $19 \%$ of total site potable water consumption. All water discharged from these systems (blow-down and overflow) is directed to the storm sewer system, and therefore is not subject to additional sanitary

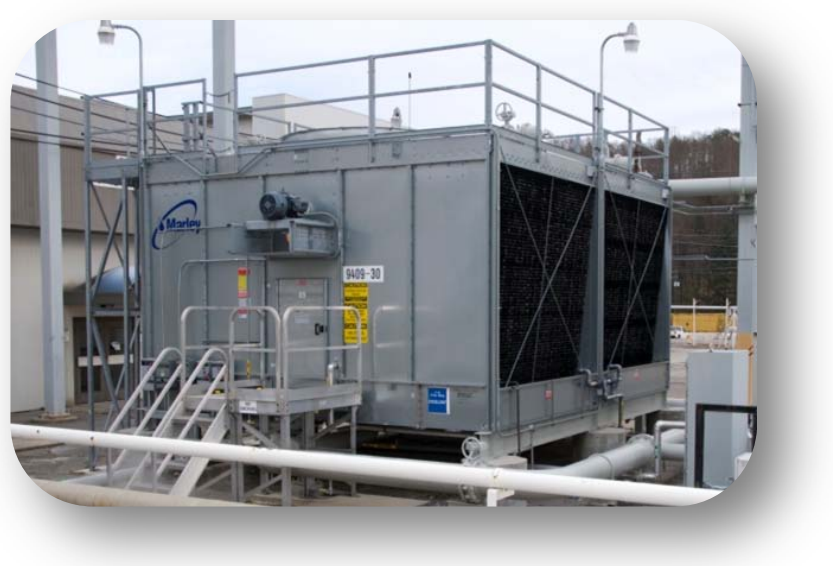

Figure 3.4. Sample Y-12 Cooling Tower sewer treatment charges.

\subsubsection{Space Cooling}

Space cooling at Y-12 is achieved by a number of different types of refrigeration equipment. The largest contributor is through closed-loop chiller systems. Water is consumed through these systems at the cooling tower only. Direct expansion (DX) units are used at many of the smaller office buildings. These systems are an air-to-air heat exchange and also consume no water. Older water-cooled air conditioning units were found in a few buildings at the Y-12 site. These systems use once-through potable water as the heat exchange medium for cooling.

Potable water consumed by the once-through water-cooled air conditioning systems is estimated at $23,220 \mathrm{kgal} / \mathrm{yr}$, or $1.7 \%$ of total site potable water consumption. All water discharged from these systems is directed to the storm sewer system and is not subject to sanitary sewer treatment charges. 


\subsubsection{Steam Plant}

The Y-12 steam plant consumes water for the production of steam. Water consumption by the steam plant occurs at three stages. First, water is rejected from the reverse osmosis (RO) treatment system that pre-filters water or dissolved minerals before being sent to the boilers. Second, the boilers use the purified water to produce steam to be distributed throughout the Y-12 site. Lastly, blow-down is required for each of the boilers to remove any residual mineral content that precipitates out of the purified water when steam is produced.

In total, steam plant water consumption is estimated at $203,121 \mathrm{kgal} / \mathrm{yr}$, or $15 \%$ of total site potable water consumption. Water discharged from $\mathrm{RO}$ reject is currently discharged to the sanitary sewer system, although evaluations are underway to determine if this water can be directed to storm sewer systems. Water discharged from blow-down is directed to sanitary sewer lines due to extremely high mineral content of the water. Steam that is produced eventually turns into condensate where a small amount of it is returned for re-use, but the majority of it is discharged to the storm sewer system.

\subsubsection{Demineralization Plant}

Y-12 has a demineralization plant that is used to remove dissolved minerals from the water so that it can be used in various laboratory and process applications throughout the site. The current demineralization plant at Y-12 had been using steam condensate as its water source. The ESPC that is currently underway at Y-12, however, includes a condensate recovery system that will direct steam condensate back to the steam boilers, as well as a new demineralization plant that will optimize water and energy consumption. Potable water is currently being supplied to the existing demineralization plant, until the new plant is constructed.

The new plant will use a high efficiency system for production of demineralized water. The system design calls for potable water to be supplied to a train of RO and electro-deionizer (EDI) systems. In addition to purified product water that is generated from these systems, a portion of the supplied water is rejected to the sanitary sewer system. In total, the demineralization plant accounts for $72,793 \mathrm{kgal} / \mathrm{yr}$, or $5.3 \%$ of total site potable water consumption.

\subsubsection{Irrigation}

Irrigation systems were identified at Y-12 at the Jack Case Center (JCC) only. The controller is a typical commercial timer-based system. The JCC staff indicated that this system is generally kept offline except in times of drought. For this reason, irrigation accounts for approximately $479 \mathrm{kgal} / \mathrm{yr}$, which is less than $0.03 \%$ of total site potable water consumption.

\subsubsection{Miscellaneous and Unaccounted Usage}

Miscellaneous usage is classified as any category of use that is not included in the systems mentioned above. Some examples of miscellaneous usage include drinking fountains, 
coffeemakers, personal water consumption (e.g., plate washing, drinking), janitorial use, and various other tasks.

Unaccounted usage is identified as water consumption that occurs at the Y-12 site, but could not be placed into a specific consumption category. Typical water balances for large industrial facilities will allocate between $10 \%$ - $20 \%$ of consumption into the miscellaneous and unaccounted usage category. The large allocation at Y-12 is due in part to the assessment team's limited access of secure facilities, as well as an effort to remain conservative in savings potential.

In total, miscellaneous and unaccounted usage at $\mathrm{Y}-12$ has been estimated to be approximately $226,688 \mathrm{kgal} / \mathrm{yr}$, or $16.5 \%$ of total site potable water consumption.

\subsubsection{Losses}

Various system losses occur in any water distribution system in the form of leaks, overflow, or damaged equipment. Many leaks are so small that they go unnoticed for years, and as distribution systems age leaks are likely to increase in intensity. For the purposes of this assessment and water balance, a system loss of $4 \%$ was assumed which is a conservative of distribution systems of this age ${ }^{1}$, which equates to approximately 55,348 kgal/yr. Considering the Y-12 potable water distribution system as a whole, the loss estimate presented here could be accounted for by approximately 105 virtually invisible pinhole leaks with flow rates of $1.0 \mathrm{gpm}$. Over the 28 miles of underground piping, this would represent an average of one of these small leaks per 1,400 foot of distribution piping.

\footnotetext{
${ }^{1}$ Source for this information is the American Water Works Association M-36 Manual, "Water Audits and Loss Control Program,” 2009, Denver, CO.
} 



\section{Chapter 4 Water Utility Information}

\subsection{Water Sources}

\subsubsection{Potable Water Supply}

Potable water is supplied by the City of Oak Ridge through three independent mains fed from the city's water treatment plant. Potable water is supplied for all sanitary water and fire protection systems through a direct connection to the Y-12 National Security Complex's (Y-12's) distribution system, and for process water systems through reduced-pressure backflow preventers to eliminate the possibility of potential contamination of the potable water supply.

Y-12's average daily water usage is 3,606 kgal, with peak demands of nearly 5,500 kgal/day. This equates to an average of 1,316,215 kgal annually. For the purposes of E.O. 13514, the FY2007 consumption serves as the baseline for consumption reduction goals. Y-12, however, experienced water meter failure during that fiscal year and therefore recorded lower consumption than was actually used. For this reason, the FY2007 potable water baseline has been adjusted to account for this discrepancy. Refer to Appendix B to find an explanation on the adjusted FY2007 baseline.

Table 4.1 shows 7.5 years of historical water usage data. The Y-12 Complex is billed for water consumption based on master water meter readings at each of the three water mains that supply the site. As mentioned previously, the water meters were replaced due to inaccurate measurements of consumption. Figure 4.1 shows a seven-year historical graph of potable water consumption at Y-12. Note that the FY2007 data is far below that of any other year. For the purposes of this water assessment, the monthly values for the baseline were calculated by taking the seven-year average, excluding the FY2007 data that is inaccurate due to failed meters. It should be noted that for this reason, the FY2007 potable water-use baseline that is used to track water reduction goal should be adjusted to account for this inaccurate data.

Table 4.1. Historical Potable Water Consumption Data at Y-12

\begin{tabular}{|c|c|c|c|c|c|c|c|c|c|c|c|c|c|c|}
\hline \multirow{9}{*}{$\begin{array}{l}\text { Potable } \\
\text { Water }\end{array}$} & kgal & Oct & Nov & Dec & Jan & Feb & Mar & Apr & May & Jun & Jul & Aug & Sep & Total \\
\hline & FY2003 & 130,385 & 128,921 & 132,576 & 132,456 & 121,515 & 128,031 & 126,075 & 112,237 & 118,403 & 127,741 & 133,800 & 134,830 & $1,526,970$ \\
\hline & FY2004 & 152,848 & 136,946 & 125,364 & 126,876 & 127,847 & 132,501 & 133,500 & 122,724 & 113,149 & 122,335 & 116,780 & 131,030 & $1,541,900$ \\
\hline & FY2005 & 134,777 & 107,058 & 114,377 & 109,237 & 95,045 & 103,896 & 120,124 & 128,276 & 126,147 & 146,553 & 150,129 & 155,500 & $1,491,119$ \\
\hline & FY2006 & 155,500 & 166,013 & 175,698 & 181,765 & 177,195 & 108,629 & 110,705 & 128,415 & 121,990 & 103,280 & 119,505 & 117,952 & $1,666,647$ \\
\hline & FY2007 & 82,461 & 69,933 & 60,658 & 61,399 & 60,765 & 60,412 & 72,906 & 69,793 & 67,983 & 65,578 & 67,704 & 66,598 & 806,190 \\
\hline & FY2008 & 82,591 & 110,676 & 92,356 & 87,600 & 93,355 & 83,851 & 101,416 & 83,899 & 96,984 & 80,132 & 112,740 & 115,018 & $1,140,618$ \\
\hline & FY2009 & 114,065 & 111,725 & 93,001 & 114,718 & 108,595 & 91,646 & 93,198 & 92,216 & 87,377 & 98,060 & 99,772 & 95,311 & $1,199,684$ \\
\hline & FY2010 & 98,596 & 81,342 & 89,934 & 93,131 & 97,890 & 70,601 & 77,960 & & & & & & 609,454 \\
\hline \multicolumn{2}{|c|}{ FY03 - FY10 Average } & 118,903 & 114,077 & 110,496 & 113,398 & 110,276 & 97,446 & 104,486 & 105,366 & 104,576 & 106,240 & 114,347 & 116,606 & $1,316,215$ \\
\hline \multicolumn{2}{|c|}{$\begin{array}{c}7 \text { Year Historical Average (excluding } \\
\text { FY07 faulty meter year) }\end{array}$} & 123,458 & 119,595 & 116,725 & 119,898 & 116,465 & 102,075 & 108,433 & 110,448 & 109,804 & 112,049 & 121,010 & 123,750 & $1,383,708$ \\
\hline
\end{tabular}

The potable water rate for $\mathrm{Y}-12$ is $\$ 1.32$ per kgal. This rate is approximately $63 \%$ less than the current commercial rate of water from the City of Oak Ridge. Most likely this reduced cost is due to the relative volume of water used by $\mathrm{Y}-12$. 


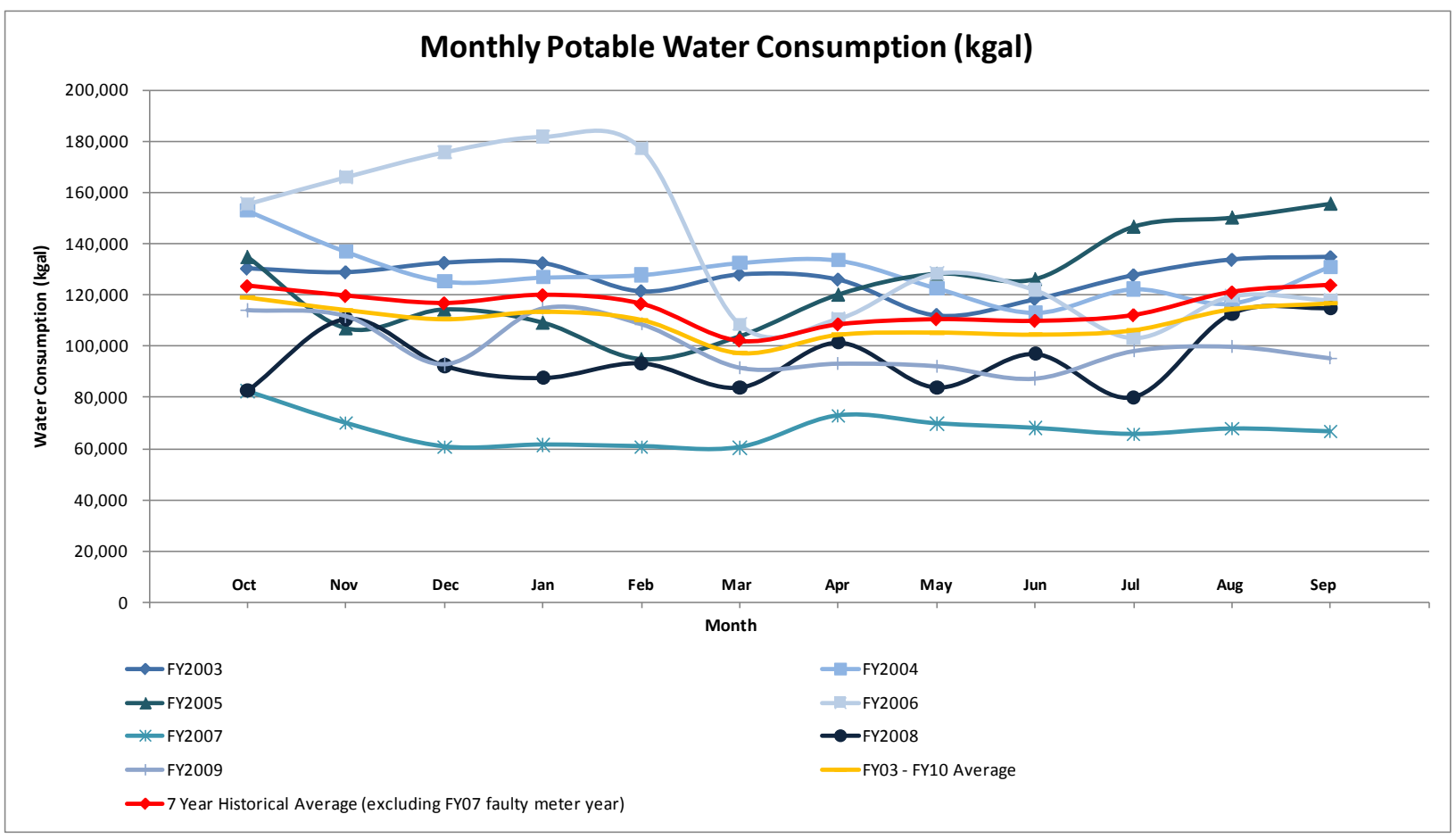

Figure 4.1. Historical Potable Water Consumption Plot at Y-12

\subsubsection{Augmentation Water}

Y-12’s National Pollutant Discharge Elimination System (NPDES) permit established a water quality standard that must be maintained in the East Fork Poplar Creek. In order to comply with this permit, a stream flow of 7 million gallons per day must be maintained. $\mathrm{Y}-12$ is permitted to release a portion of the potable water through the storm drainage system into the East Fork Poplar Creek. This creek also receives flow through precipitation, natural surface run-off, and ground water. (More information is provided on East Fork Poplar Creek discharge flows in Section 4.2.2 of this assessment document.) But these flows are not

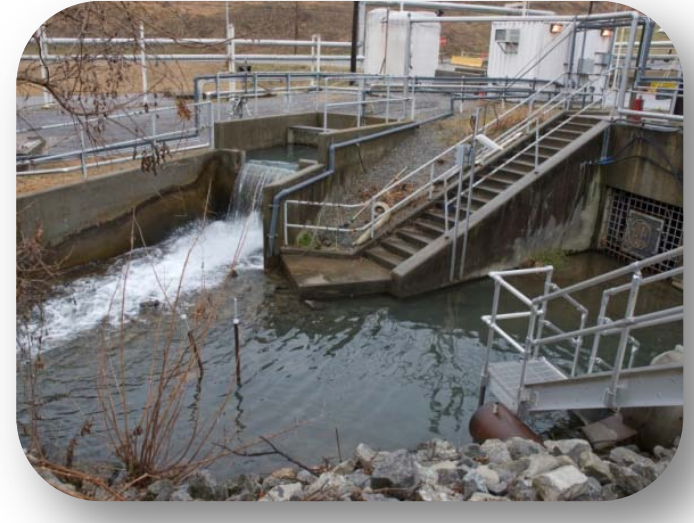

Figure 4.2. Augmentation Water Supply at the Head Waters of the East Fork Poplar Creek always adequate to meet the discharge requirements, so additional water is required to augment the flow into East Fork Poplar Creek. Therefore, Y-12 purchases non-potable water from the City of Oak Ridge to supplement the flow into East Fork Poplar Creek, called "augmentation water." The augmentation water is supplied at the head waters of the East Fork Poplar Creek, as shown in Figure 4.2. Since the augmentation water is only partially treated (not of sufficient quality for human consumption), the City of Oak Ridge bills for this water a lower rate, which is currently $\$ 0.33$ per kgal. 
Recent changes in the NPDES permit have reduced the required stream flow to 5 million gallons per day. This permit change will reduce the required amount of augmentation water by approximately $46 \%$, which equates to a utility cost savings of $\$ 240,900$ per year.

\subsubsection{Stormwater/Groundwater}

The City of Oak Ridge averages 55.05 inches of seasonal rainfall. The Y-12 Complex encompasses over 811 acres of land, which equates to 1,215 million gallons of rain that is absorbed into the ground or discharged through the complex's stormwater system that eventually feeds the East Fork Poplar Creek. Ongoing smoke testing of sanitary sewer lines has revealed points of infiltration and cross-connection from roof and curb storm drains. An estimated $10,025 \mathrm{kgal}$ per year of rainwater is suspected to infiltrate the sanitary sewer system. This amounts to a utility cost $\$ 94,035$ per year. It is highly recommended to identify and repair any cross-connections or infiltration points in order to mitigate these charges. Because the focus of the assessment is on efficiency improvements and not cross-connection issues, further analysis was not performed on this problem.

Groundwater is another small source of water that is transferred to the East Fork Poplar Creek storm drainage system. The buildings along the southern side of the Y-12 Complex require de-watering so that natural spring water is diverted before building infiltration can occur, as shown in Figure 4.3. The groundwater is pumped via sump basins located in the basement/crawl space areas of the buildings, out to the East Fork Poplar Creek outfalls. The amount of groundwater contributing to the total storm drainage is minimal, accounting for less than $1 \%$ of the total flow.

\subsection{Water Outflows}

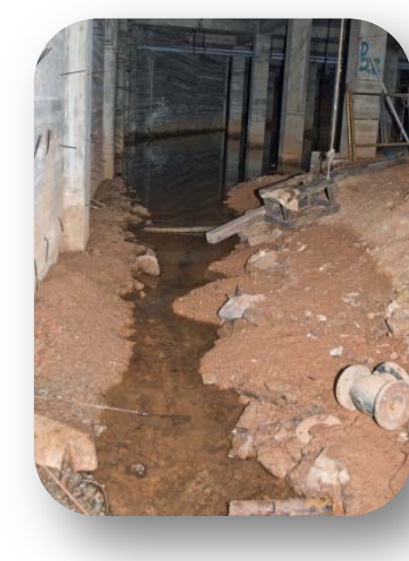

Figure 4.3. Groundwater Infiltration into Building Crawl Spaces

\subsubsection{Sanitary Sewer Discharge}

Sanitary waste that is generated at the Y-12 Complex is treated by the City of Oak Ridge. Sewer consumption is billed based on meter readings from a weir-type sewer meter located at the east end of the Y-12 Complex. Therefore, only water and sewage that is discharged through the sanitary sewer system is billed for sewer charges. All evaporation from cooling towers, water applied through irrigation, and any process or equipment cooling water that is discharged through the storm drainage system is exempt from sewer charges. The average rate for sanitary sewer charged by the City of Oak Ridge is $\$ 9.38$ per kgal. The Y-12 Complex produces an average daily discharge of $631 \mathrm{kgal}$, which equates to 230,164 kgal annually. Approximately $15-18 \%$ of the potable water supply eventually enters the sanitary sewer system, while all other potable water supplied to the site is either discharged via the storm drainage system, or lost to ground absorption or evaporation. 
The City of Oak Ridge has placed discharge limits on Y-12 so it can mitigate the potential for sewer distribution system overflow downstream of Y-12. As previously mentioned, stormwater infiltration into the sanitary sewer is a problem at $\mathrm{Y}-12$, and it appears that major rain events have caused Y-12 to exceed the permitted flow limits of the sanitary sewer.

Y-12 has a monitoring system for the sanitary sewer system called the surface water hydrological information support system (SWHISS). This automated meter-reading system can measure flows at 5-minute intervals to provide real time data to Y-12 on sanitary flows. The SWHISS also monitors flows of the East Fork Poplar Creek (find more information in the next section). The SWHISS software is designed to send alarms when the permitted limits of discharge are going to be exceeded. This system does not, however, prevent the exceedances from occurring, and only provides advanced warning of such occurrences. The SWHISS is managed by the environmental group at $\mathrm{Y}-12$.

Figure 4.4 shows the correlation between rain events and the surge in sanitary sewer flow rates. Data for this graph was captured through the SWHISS. This is a definitive indication that stormwater infiltration occurs.

\subsubsection{East Fork Poplar Creek Stormwater Discharge}

The storm sewer system at the Y-12 Complex consists of five major components that collect and channel rainwater, surface/groundwater, various process discharges, cooling tower blowdown and overflow, and a variety of other industrial/mechanical water discharges. The first component consists of the underground piping system, which includes roof and curb drains that collect storm water runoff as well as the aforementioned variety of discharges from the Y-12 facilities. The underground system is divided into 19 sub-drainage basins that are equipped with dechlorination systems, where discharged water is collected and chlorine is removed. These collection stations serve as the second major component of the storm sewer system. The dechlorinated water is then discharged through outfalls into the third major component, the East Fork Poplar Creek.

The East Fork Poplar Creek lies on the southern side of the Y-12 Complex along a valley low point between the surrounding ridges. The creek's flow is generated primarily from the head waters produced by the augmentation water mentioned above, in addition to natural runoff from the surrounding topography. Each of the 19 outfalls supplements the flow of the creek as it travels towards the east end of the Y-12 Complex. After the last outfall, the flow of water is passed through the fourth major component, which is an engineered oil separator. This separator removes floating debris and oil from the flow of water before it continues downstream. The fifth and final component of the Y-12 storm sewer system is a 4,000- $\mathrm{ft}^{2}$, synthetically lined lake, called Lake Reality that serves as a spill containment basin for the East Fork Poplar Creek. In the event of chemical spill, or other emergency, the creek waters can be diverted into Lake Reality for collection and treatment, so that contaminants are not allowed to leave the site. If not diverted, the creek continues to flow downstream into the City of Oak Ridge where it serves as a supply for natural wetlands and protected habitats. 


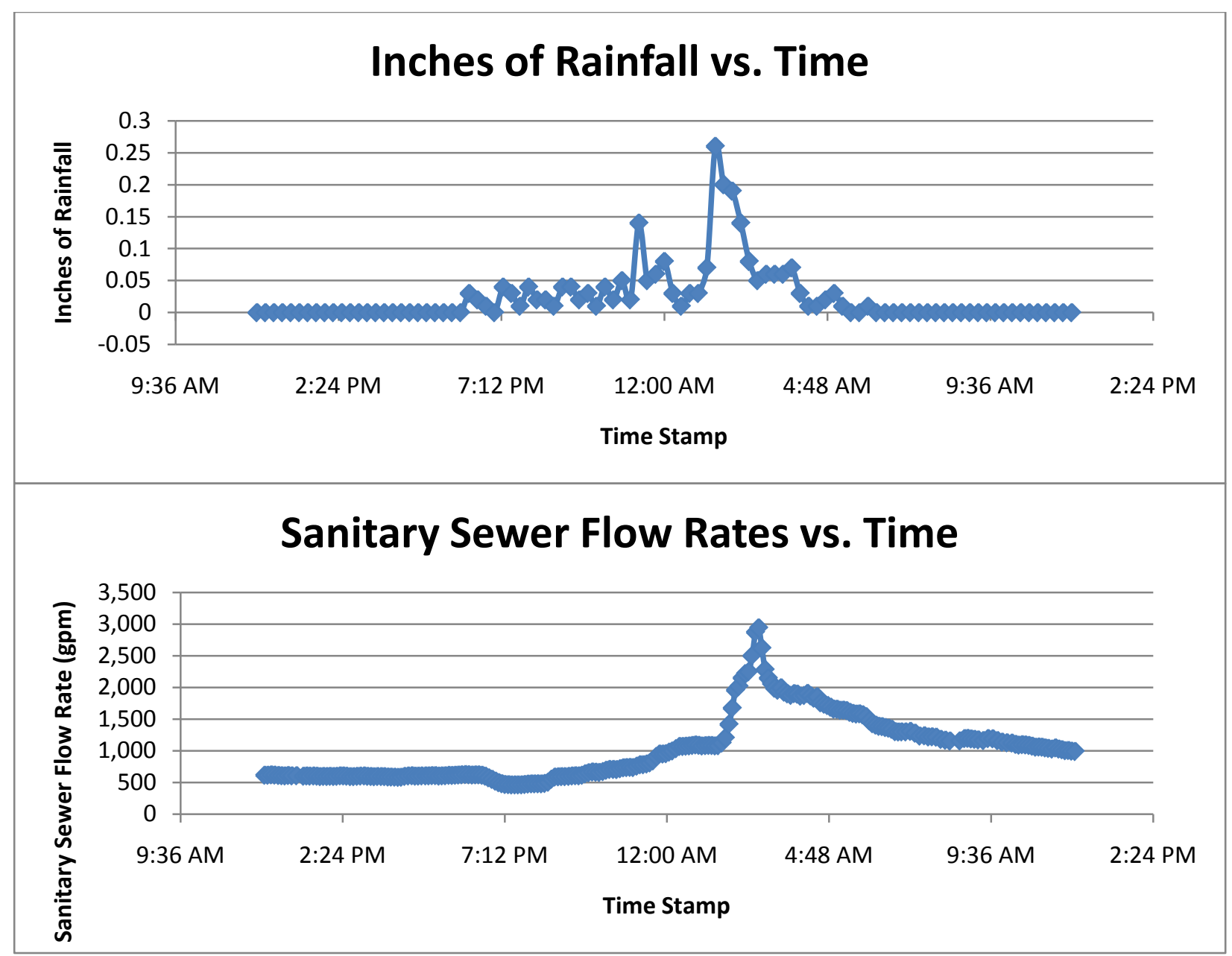

Figure 4.4. Correlation between Rain Events and Sanitary Sewer Flow Rates at Y-12

There is no maximum limit to the amount of water that can be discharged through this system. There is, however, as mentioned above, a minimum amount of water that must be supplied. The primary reason for this minimum water flow permit is to protect the natural habitats downstream of the Y-12 Complex. In the past, Y-12's plant operations discharged significantly more water than it does currently, and essentially created the natural habitats downstream. Now that the facility function has evolved over the years, the Y-12 Complex is required to maintain the water supply to ecosystems created 70 years ago. 



\section{Chapter 5 Water Efficiency Opportunities}

\subsection{Water Balance}

The water-assessment team developed a "water balance" for the Y-12 National Security Complex's (Y-12's) water system based on information gathered through the walkthrough surveys. Y-12 staff led the group of water auditors through the buildings and directed the team to water-intensive equipment. Because of security reasons, the water assessment team was not able to go through all of the major buildings and processes at Y-12. So the assessment team developed "audit checklists" so that Y-12 staff could gather the needed information for the assessment team to assist in the development of the water balance. Refer to Appendix C to find a listing of these sample checklists.

The water balance represents the major water users and quantifies each category to help identify the largest water users at Y-12. Figure 5.1 illustrates the water flow balance of all categories of water supply and use at Y-12. Estimated consumption values for each category have been assigned based on results from the onsite inspection.

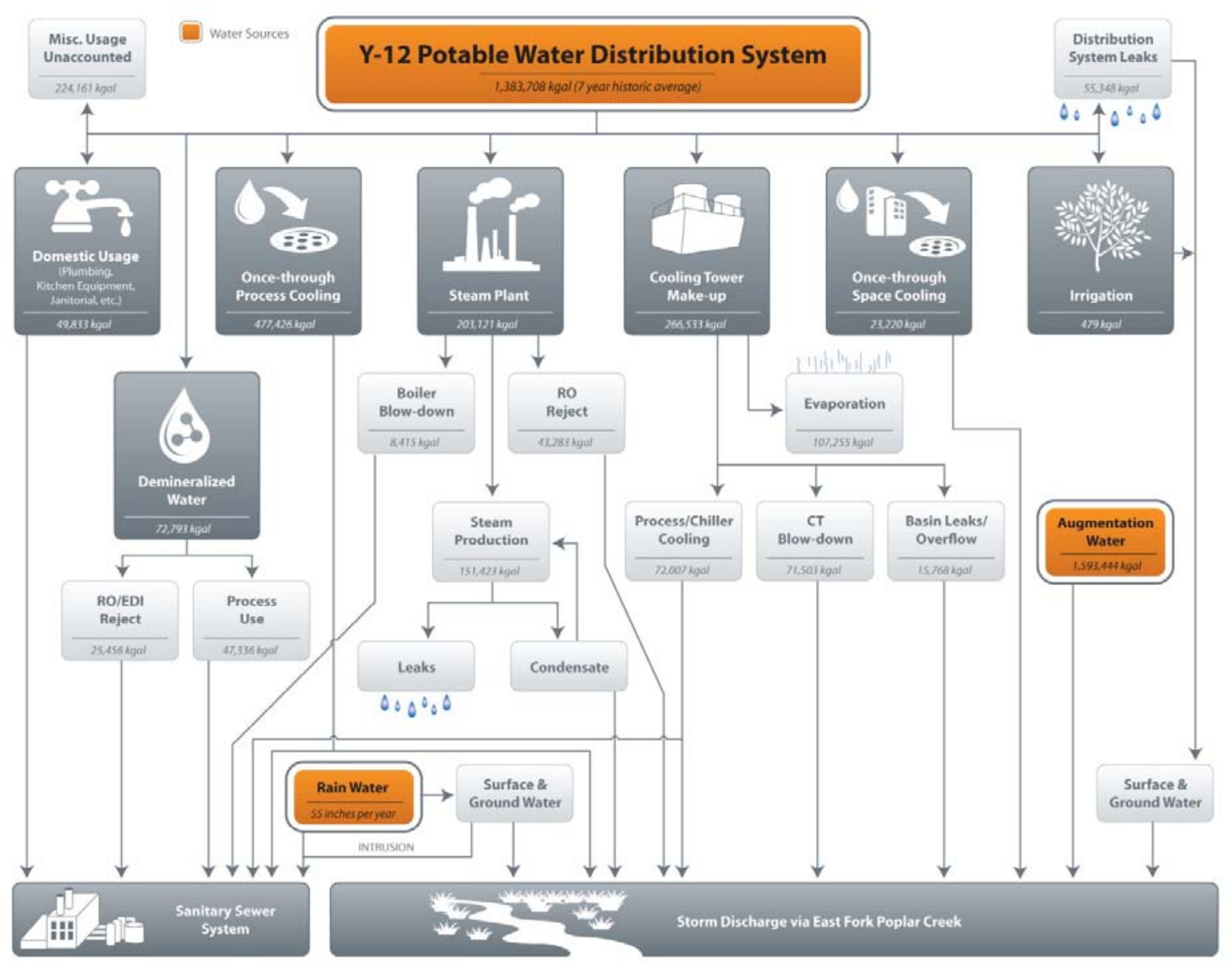

Figure 5.1. Y-12 Water Flow Diagram 
A water balance chart has been prepared as shown in Figure 5.2, in order to compartmentalize water use at Y-12. Appropriate percentages have been applied to each major category of consumption.

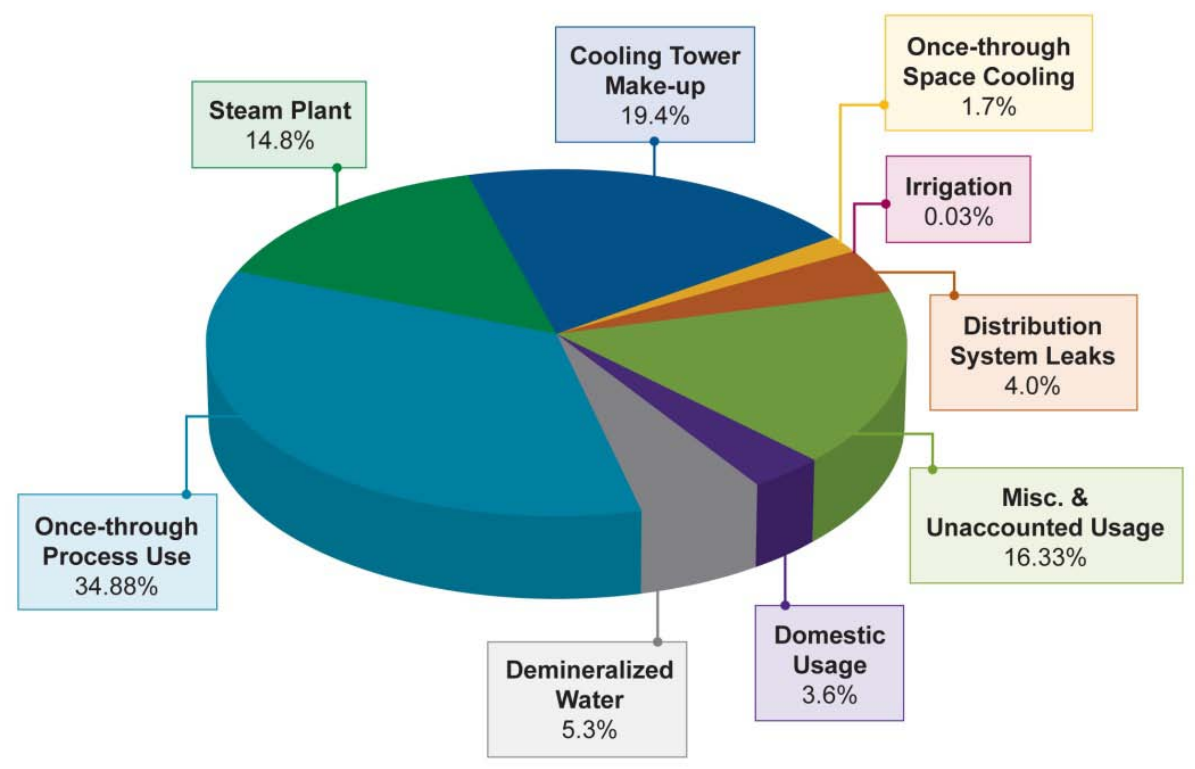

Figure 5.2. Water Balance Chart for Major Use Categories

\subsection{Overview of Recommendations}

The water-assessment team has identified eighteen unique water and energy conservation measures designed to improve the water efficiency of Y-12. Table 5.1 has been prepared to summarize all recommendations identified in this water assessment along with associated implementation costs and potential savings. The recommendations include domestic plumbing fixture retrofits including high efficiency toilets, urinals, faucets, and showerheads; upgrades or replacement of commercial kitchen equipment; process cooling connection repairs; and steam plant and cooling tower upgrades. It should be noted that the measure for replacing the single pass space cooling with an air cooled system showed a negative payback due to an increase in energy use. Also, the measure for replacing water-cooled ice machines with air-cooled machines shows a small increase in energy use. These items are shown in red font in Table 5.1. Each recommendation is discussed in greater detail in Sections 5.3 through 5.12 of this assessment document. 
Table 5.1. Water Efficiency Recommendations

\begin{tabular}{|c|c|c|c|c|c|c|c|c|c|}
\hline WCM \# & WCM Description & Est. Count & $\begin{array}{l}\text { Est. Total } \\
\text { Water / Sewer } \\
\text { Savings } \\
\text { (gal/yr) }\end{array}$ & $\begin{array}{c}\text { Est. Total } \\
\text { Water / } \\
\text { Sewer } \\
\text { Savings } \\
\text { (\$\$/yr) }\end{array}$ & $\begin{array}{l}\text { Est. Total } \\
\text { Energy } \\
\text { Savings } \\
\text { (kbtu/yr) }\end{array}$ & $\begin{array}{l}\text { Est. Total } \\
\text { Energy } \\
\text { Savings } \\
\text { (\$\$/yr) }\end{array}$ & $\begin{array}{l}\text { Est. Total } \\
\text { Annual } \\
\text { Savings } \\
\text { (\$\$/yr) }\end{array}$ & $\begin{array}{c}\text { Est. Total } \\
\text { Installed Cost } \\
\text { (\$\$) }\end{array}$ & $\begin{array}{l}\text { Overall } \\
\text { Simple } \\
\text { Payback } \\
\text { (yrs) }\end{array}$ \\
\hline 1 & $\begin{array}{l}\text { Upgrade toilets to HET units (1.28 gpf flush } \\
\text { valve, } 1.0 \mathrm{gpf} \text { tank) }\end{array}$ & 1,077 & $10,539,100$ & $\$ 112,768$ & 0 & $\$ 0$ & $\$ 112,768$ & $\$ 656,523$ & 5.82 \\
\hline 2 & Upgrade urinals to HEU 0.5 gpf piston units & 400 & $3,919,500$ & $\$ 41,939$ & 0 & $\$ 0$ & $\$ 41,939$ & $\$ 153,720$ & 3.67 \\
\hline 3 & $\begin{array}{l}\text { Install faucet restrictors } \\
\text { ( } 0.5 \mathrm{gpm} \text { lavatory, } 1.0 \mathrm{gpm} \text { kitchen/lab) }\end{array}$ & 1,454 & $1,602,640$ & $\$ 17,148$ & 273,256 & $\$ 1,966$ & $\$ 19,115$ & $\$ 87,284$ & 4.57 \\
\hline 4 & $\begin{array}{l}\text { Install } 1.5 \mathrm{gpm} \text { low-flow pressure } \\
\text { compensating showerheads }\end{array}$ & 503 & $9,322,560$ & $\$ 99,751$ & $4,034,122$ & $\$ 29,030$ & $\$ 128,781$ & $\$ 10,066$ & 0.08 \\
\hline 5 & $\begin{array}{l}\text { Install high efficiency dish machine with Opti- } \\
\text { Rinse technology }\end{array}$ & 1 & 124,800 & $\$ 1,335$ & 149,979 & $\$ 11,606$ & $\$ 12,941$ & $\$ 71,066$ & 5.49 \\
\hline 6 & $\begin{array}{l}\text { Install in-line flow restrictors on garbage } \\
\text { disposal nozzle supply lines }\end{array}$ & 1 & 149,760 & $\$ 1,602$ & 0 & $\$ 0$ & $\$ 1,602$ & $\$ 2,036$ & 1.27 \\
\hline 7 & $\begin{array}{l}\text { Install in-line flow restrictors on tray } \\
\text { conveyor trough nozzle supply lines \& install } \\
\text { timer-based solenoid controls }\end{array}$ & 1 & 524,160 & $\$ 5,609$ & 0 & $\$ 0$ & $\$ 5,609$ & $\$ 4,668$ & 0.83 \\
\hline 8 & Install $1.28 \mathrm{gpm}$ pre-rinse sprayers & 3 & 83,741 & $\$ 896$ & 45,296 & $\$ 261$ & $\$ 1,157$ & $\$ 702$ & 0.61 \\
\hline 9 & $\begin{array}{l}\text { Replace existing steamers with high } \\
\text { efficiency connectionless steamer units }\end{array}$ & 4 & 93,808 & $\$ 1,004$ & 151,103 & $\$ 2,384$ & $\$ 3,388$ & $\$ 37,485$ & 11.06 \\
\hline 10 & $\begin{array}{l}\text { Install counter-flow heat exchangers on all } \\
\text { existing and proposed ice machines }\end{array}$ & 23 & 0 & $\$ 0$ & 125,227 & $\$ 1,976$ & $\$ 1,976$ & $\$ 16,431$ & 8.32 \\
\hline 11 & $\begin{array}{l}\text { Replace existing water-cooled ice machines } \\
\text { with air-cooled equivalents }\end{array}$ & 2 & 386,880 & $\$ 4,140$ & $(7,241)$ & $(\$ 114)$ & $\$ 4,025$ & $\$ 26,000$ & 6.46 \\
\hline 12 & $\begin{array}{l}\text { Repair condenser loop connections so that all } \\
\text { condenser water is returned to the cooling } \\
\text { towers }\end{array}$ & 12 & $57,738,123$ & $\$ 76,214$ & 0 & $\$ 0$ & $\$ 76,214$ & $\$ 336,000$ & 4.41 \\
\hline 13 & $\begin{array}{l}\text { Install advanced sub-metering systems for } \\
\text { cooling towers }\end{array}$ & 9 & 0 & $\$ 0$ & 0 & $\$ 0$ & $\$ 0$ & $\$ 99,722$ & - \\
\hline 14 & $\begin{array}{l}\text { Install conductivity controllers for cooling } \\
\text { towers }\end{array}$ & 9 & $29,318,668$ & $\$ 38,701$ & 0 & $\$ 0$ & $\$ 38,701$ & $\$ 108,731$ & 2.81 \\
\hline 15 & $\begin{array}{l}\text { Install side-stream filtration or hydrodynamic } \\
\text { cavitation systems for cooling towers }\end{array}$ & 9 & $42,645,335$ & $\$ 56,292$ & $9,250,645$ & $\$ 145,956$ & $\$ 202,248$ & $\$ 2,672,667$ & 13.21 \\
\hline 16 & $\begin{array}{l}\text { Replace existing water-cooled air } \\
\text { conditioning system with air-cooled } \\
\text { equivalents }\end{array}$ & 45 & $23,220,432$ & $\$ 30,651$ & $(18,184,464)$ & $(\$ 286,913)$ & $(\$ 256,262)$ & $\$ 2,892,857$ & $\begin{array}{l}\text { not cost } \\
\text { effective }\end{array}$ \\
\hline 17 & $\begin{array}{l}\text { Install advanced sub-metering systems for } \\
\text { steam plant }\end{array}$ & 1 & 0 & $\$ 0$ & 0 & $\$ 0$ & $\$ 0$ & $\$ 44,898$ & - \\
\hline 18 & $\begin{array}{l}\text { Extend condensate recovery project to } \\
\text { include additional end use capture sites for } \\
\text { condensate return }\end{array}$ & - & $48,484,848$ & $\$ 64,000$ & $44,468,745$ & $\$ 256,000$ & $\$ 320,000$ & $\$ 4,500,000$ & 14.06 \\
\hline & Steam Plant Upgrades TOTAL & & $48,484,848$ & $\$ 64,000$ & $44,468,745$ & $\$ 256,000$ & $\$ 320,000$ & $\$ 4,544,898$ & 14.20 \\
\hline
\end{tabular}

\subsection{Domestic Plumbing Fixtures}

Vast improvements have been made in the design and efficiency of domestic plumbing fixtures over the last decade. Installation of high efficiency toilets (HET), high efficiency urinals (HEU), piston-type flush valves, faucet restrictors, and efficient pressure compensating showerheads can reduce domestic plumbing water/sewer consumption by as much as $50-65 \%$, depending on the existing conditions of current equipment. 
Table 5.2 provides a cost and savings summary for the recommended domestic plumbing improvements.

Table 5.2. Domestic Plumbing Cost and Savings Summary

\begin{tabular}{|c|c|c|c|c|c|c|c|c|c|}
\hline WCM \# & WCM Description & Est. Count & $\begin{array}{c}\text { Est. Total } \\
\text { Water / Sewer } \\
\text { Savings } \\
\text { (gal/yr) } \\
\end{array}$ & $\begin{array}{c}\text { Est. Total } \\
\text { Water / } \\
\text { Sewer } \\
\text { Savings } \\
\text { (\$\$\$yr) }\end{array}$ & $\begin{array}{l}\text { Est. Total } \\
\text { Energy } \\
\text { Savings } \\
\text { (kbtu/yr) }\end{array}$ & $\begin{array}{c}\text { Est. Total } \\
\text { Energy } \\
\text { Savings } \\
\text { (\$\$/yr) }\end{array}$ & $\begin{array}{c}\text { Est. Total } \\
\text { Annual } \\
\text { Savings } \\
\text { (\$\$/yr) }\end{array}$ & $\begin{array}{l}\text { Est. Total } \\
\text { Installed } \\
\text { Cost } \\
\text { (\$\$) }\end{array}$ & $\begin{array}{c}\text { Overall } \\
\text { Simple } \\
\text { Payback } \\
\text { (yrs) } \\
\end{array}$ \\
\hline \multicolumn{2}{|r|}{ Domestic Plumbing Retrofits TOTAL } & & $25,383,800$ & $\$ 271,607$ & $4,307,378$ & $\$ 30,996$ & $\$ 302,603$ & $\$ 907,593$ & 3.00 \\
\hline
\end{tabular}

\section{Technical Approach and Calculation Methodology}

Domestic plumbing fixtures follow the same general methodology. Pre- and postconsumption is determined by fixture usage per day, multiplied by days per year, multiplied by pre- and post-flow rates. Please refer to Appendix A that provides the assumptions used in these calculations.

\subsubsection{Toilets}

\section{Equipment Summary}

High efficiency toilets (HET) are designed to not exceed 1.28 gallons per flush (gpf), which is a $20 \%$ reduction in consumption from the standard $1.6 \mathrm{gpf}$, and a $63 \%$ reduction in consumption from their older 3.5 gpf predecessors. Commercial flush-valve type HETs are designed at 1.28 gpf while tank-type HETs are designed at 1.0, or 1.1, gpf, and include a pressure vessel instead of the traditional gravity-fed flapper assembly, which helps to reduce maintenance and clogging.

While toilet and urinal fixture design is important for a quality performance, the flush valve is the most crucial aspect to optimizing the water efficiency of the fixture. There are two main types of flush valves, diaphragm and piston. The water-assessment team recommends installing piston-type valves in replacement of any existing commercial diaphragm-type flushometers. Piston valves offer several benefits:

- Piston valves are precise, and deliver the desired flow, even as they age. Piston valves perform at $\pm 5 \%$ accuracy of the designed flow, whereas diaphragm valves are substantially less accurate near $\pm 20 \%$ of the designed flow. Diaphragm inaccuracy is more prevalent at high and low pressure extremes.

- Piston valves are more tolerant of low pressures experienced at certain times of the day and certain building applications. Piston valves are rated at a minimum pressure of 15 psi, as opposed to diaphragm-type valves that require at least 35 psi to operate accurately. 
- Piston valves are virtually maintenance free for 5 to 7 years, due to an inlet screen that lessens the probability that the valve-timing orifice will become clogged with debris. The screen is positioned such that it is backwashed with every flush. Figure 5.3 illustrates a schematic of a piston valve. The inlet screen is located in the supply tube that enters the valve body from the right side of this schematic. Diaphragm valves currently in use depend on a tiny pinhole to meter the flow of water. This pinhole will often corrode or clog, causing flush volume to increase and decrease. Diaphragms must be changed regularly, resulting in an average of

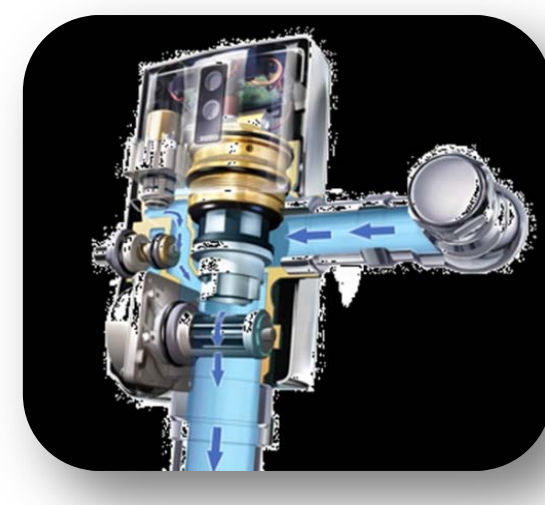

Figure 5.3. Piston Valve Schematic $\$ 5.00$ per year per valve. Piston valves reduce this additional maintenance cost due to longer life and internal components that do not need to be replaced. The valve housing of a diaphragm-type valve can accommodate any flow rate diaphragm. Thus, a common mistake is to replace an efficient valve with a higher-flow diaphragm rather than expend the time to search for or purchase the proper component. This instantly converts a high efficiency toilet into a water-wasting 3.5 gpf toilet. This presents a major concern in any guaranteed performance-based contract, as calculated savings are diminished by improper maintenance.

- Piston valves default to a closed position, whereas diaphragm-type valves default open. In the event of pressure loss, a piston valve remains closed and prevents any water from being wasted. Diaphragm-type valves, on the other hand, begin to open allowing water to pass freely through. If the pressure drop is sustained for any period of time, this can amount to a significant volume of wasted water consumption.

\section{Existing Conditions}

A variety of different toilet configurations and types, including both wall-mounted and floor-mounted commercial flush valve-type and gravity-type tank toilets, were identified during the walkthrough inspections. Approximately 862 of the commercial toilets identified included older 3.5 gpf toilet china with 3.5 gpf diaphragm-type valves. Many of these older toilets exhibited flush rates in excess of 4.0 gpf, which is common with diaphragm-type valves as the internal components begin to deteriorate with age.

Approximately 119 of the toilets identified have been upgraded, or replaced as needed, with newer $1.6 \mathrm{gpf}$ vitreous toilet china and 1.6 gpf diaphragm-type valves, as shown in Figure 5.4. Many of these toilet types exhibit flush rates in excess of 2.0 to $2.5 \mathrm{gpf}$ for reasons similar to above.

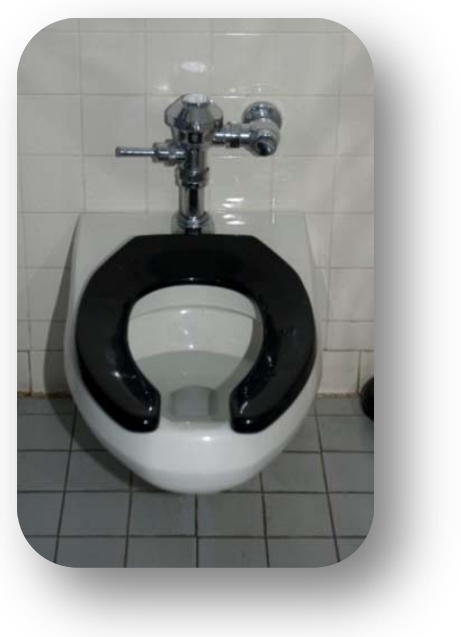

Figure 5.4. Y-12 Toilet Example 
The gravity-type tank toilets were primarily identified in office buildings. The majority of this type of toilet is older $3.5 \mathrm{gpf}$ tanks, although piecemeal replacement with newer $1.6 \mathrm{gpf}$ models has taken place throughout the site as needed.

\section{Proposed Recommendations}

All existing diaphragm-type valves are recommended for replacement with 1.28 gpf HET piston valves. Any existing 3.5 gpf toilet china is recommended for replacement with new 1.28- gpf HET vitreous toilet china to ensure that there is proper flush performance. An older style toilet bowl will not provide the proper flush pattern with reduced flush volume. Existing $1.6 \mathrm{gpf}$ low-flow toilet china does not need to be replaced and can be retrofitted with new 1.28 gpf piston valves only. Lab tests have shown that 1.28 gpf piston valves will fully evacuate the toilet trapway due to the heightened flush curve of piston valves (i.e., the full volume of water during a flush cycle is released over a shorter time at a greater velocity).

Figure 5.5 provides a representation of the typical flush curves of various valve types. It can be seen that piston valves deliver a larger volume of water at the front end of the flush, which generates a siphoning effect that increases flush force and allows for full trap evacuation with less water than diaphragm-type counterparts.

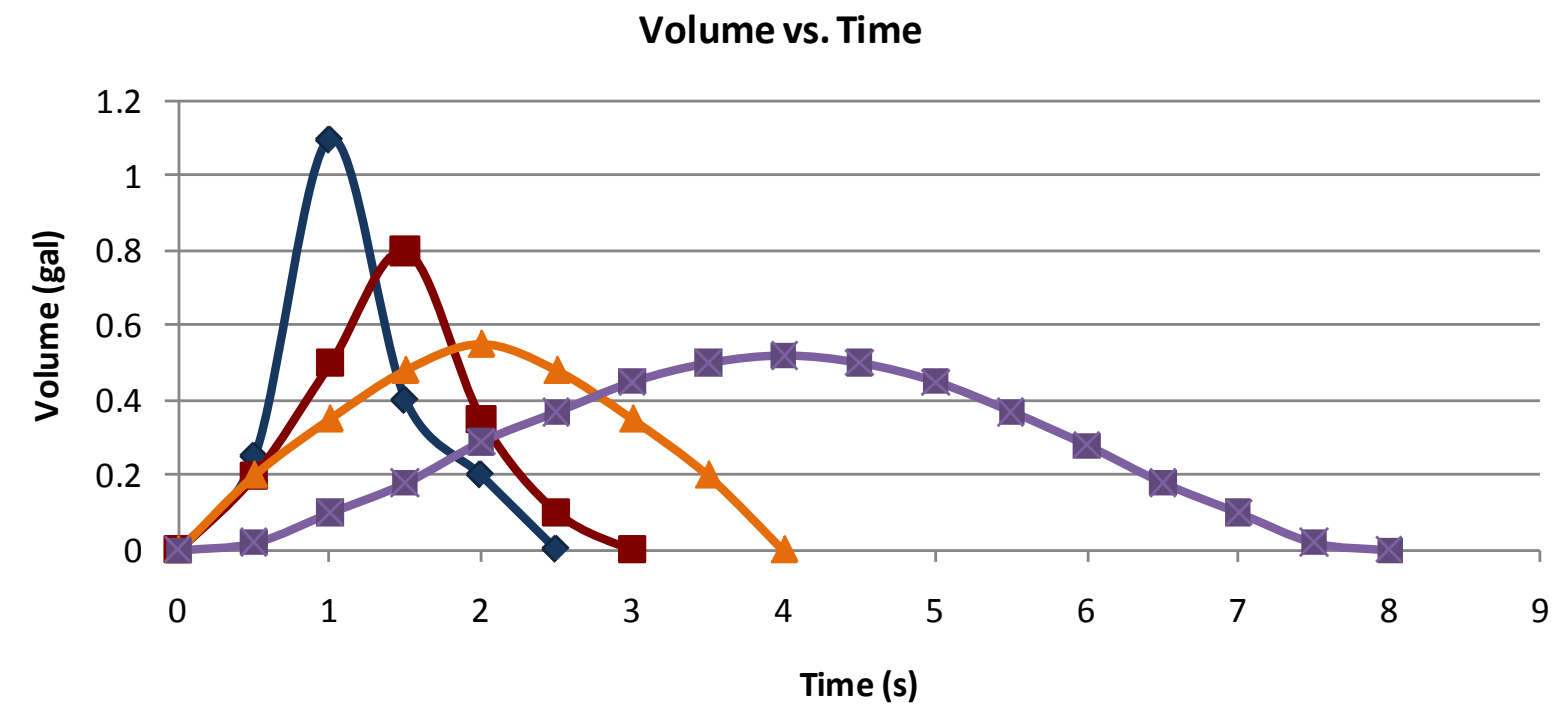

$\neg 1.28$ gpf HET Piston -1.6 gpf Piston $\leftarrow-1.6$ gpf Diaphragm -2.5 gpf Diaphragm

Figure 5.5. Flush Curve Plots

Table 5.3 provides a cost/savings summary for the recommended toilet improvements. 
Table 5.3. Toilet Cost and Savings Detail

\begin{tabular}{|c|c|c|c|c|c|c|c|c|c|}
\hline wCM \# & WCM Description & Est. Count & $\begin{array}{c}\text { Est. Total } \\
\text { Water / Sewer } \\
\text { Savings } \\
\text { (gal/yr) }\end{array}$ & $\begin{array}{c}\text { Est. Total } \\
\text { Water / } \\
\text { Sewer } \\
\text { Savings } \\
\text { (\$\$/yr) }\end{array}$ & $\begin{array}{l}\text { Est. Total } \\
\text { Energy } \\
\text { Savings } \\
\text { (kbtu/yr) }\end{array}$ & $\begin{array}{c}\text { Est. Total } \\
\text { Energy } \\
\text { Savings } \\
\text { (\$\$/yr) }\end{array}$ & $\begin{array}{l}\text { Est. Total } \\
\text { Annual } \\
\text { Savings } \\
\text { (\$\$/yr) }\end{array}$ & $\begin{array}{l}\text { Est. Total } \\
\text { Installed } \\
\text { Cost } \\
\text { (\$\$) }\end{array}$ & $\begin{array}{c}\text { Overall } \\
\text { Simple } \\
\text { Payback } \\
\text { (yrs) }\end{array}$ \\
\hline 1 & $\begin{array}{l}\text { Upgrade toilets to HET units (1.28 gpf flush } \\
\text { valve, } 1.0 \mathrm{gpf} \text { tank) }\end{array}$ & 1,077 & $10,539,100$ & $\$ 112,768$ & 0 & $\$ 0$ & $\$ 112,768$ & $\$ 656,523$ & 5.82 \\
\hline
\end{tabular}

\subsubsection{Urinals}

\section{Equipment Summary}

High efficiency urinals (HEUs) are designed to not exceed 0.5 gpf. HEUs can have a variety of different flush rates ranging from $0.125 \mathrm{gpf}$ (pint flush) up to $0.5 \mathrm{gpf}$. Standard urinals on the market consume 1.0 gpf. HEUs can create as much as a $90 \%$ reduction in consumption from typical existing fixtures. Non-water urinals are available on the market as well that use no water to flush waste, but through investigation during the water assessment, it was determined that non-water urinals are not appropriate for Y-12 due to ongoing maintenance issues and the age of the facility's sanitary sewer infrastructure.

\section{Existing Conditions}

Approximately $10 \%$ of the urinals identified during the walkthrough inspection are older-type urinal china with a large water spot (water in the basin of the urinal china). Many of these older urinals exhibited flush rates in excess of $4.0 \mathrm{gpf}$, which is common with diaphragm-type valves as the internal components begin to deteriorate with age. All other urinals identified in the walkthrough inspection consisted of newer urinal china with little or no water spot, as seen in Figure 5.6. These newer urinals are capable of complete urinal trapway evacuation with 0.5 gpf HEU piston valves.

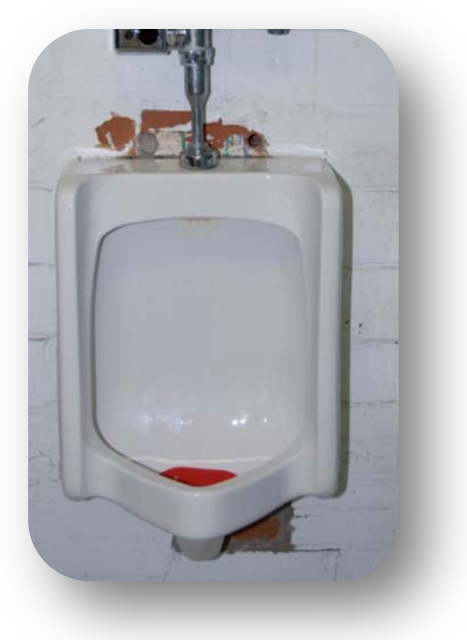

Figure 5.6. Typical Y-12 Urinal

\section{Proposed Recommendations}

All existing diaphragm-type valves are recommended for replacement with 0.5 gpf HEU piston valves. (See previous section for additional information on the advantages of piston valves.) Any urinal china incapable of being retrofitted with new HEU piston valves only (i.e., those that contain large water spots, or older pedestal-type urinals) are recommended for replacement with new 0.125 gpf vitreous urinal china.

Table 5.4 provides a cost/savings summary for the recommended urinal improvements. 
Table 5.4. Urinal Cost and Savings Detail

\begin{tabular}{|c|c|c|c|c|c|c|c|c|c|}
\hline WCM \# & WCM Description & Est. Count & $\begin{array}{c}\text { Est. Total } \\
\text { Water / Sewer } \\
\text { Savings } \\
\text { (gal/yr) }\end{array}$ & $\begin{array}{l}\text { Est. Total } \\
\text { Water / } \\
\text { Sewer } \\
\text { Savings } \\
\text { (\$\$/yr) }\end{array}$ & $\begin{array}{l}\text { Est. Total } \\
\text { Energy } \\
\text { Savings } \\
\text { (kbtu/yr) }\end{array}$ & $\begin{array}{c}\text { Est. Total } \\
\text { Energy } \\
\text { Savings } \\
\text { (\$\$/yr) }\end{array}$ & $\begin{array}{c}\text { Est. Total } \\
\text { Annual } \\
\text { Savings } \\
\text { (\$\$/yr) }\end{array}$ & $\begin{array}{l}\text { Est. Total } \\
\text { Installed } \\
\text { Cost } \\
\text { (\$\$) }\end{array}$ & $\begin{array}{c}\text { Overall } \\
\text { Simple } \\
\text { Payback } \\
\text { (yrs) }\end{array}$ \\
\hline 2 & Upgrade urinals to HEU $0.5 \mathrm{gpf}$ piston units & 400 & $3,919,500$ & $\$ 41,939$ & 0 & $\$ 0$ & $\$ 41,939$ & $\$ 153,720$ & 3.67 \\
\hline
\end{tabular}

\subsubsection{Faucets}

\section{Equipment Summary}

Faucets come in a variety of flow rates. Standard faucets cannot exceed 2.2 gallon per minute (gpm) at $60 \mathrm{psi}$, or $2.5 \mathrm{gpm}$ at $80 \mathrm{psi}$. High efficiency faucets are also available that range in flow rate from $1.5 \mathrm{gpm}$ to $0.5 \mathrm{gpm}$. It should be noted that older faucets typically contain 2.5 gpm aerators, or have unthreaded spigots that exhibit flow rates in excess of 3.0 gpm, and are incapable of being retrofitted with any type of aerator/restrictor.

Lavatory faucets can be retrofitted with $0.5 \mathrm{gpm}$ aerator or laminar flow restrictors that can decrease the consumption by as much as $80 \%$. Kitchen and laboratorystyle faucets can be retrofitted with 1.0 gpm laminar flow restrictors. The laminar restrictors provide a steady stream of water as opposed to the turbulent bubbly mix that an aerator provides. This is especially important in healthcare or food preparation areas, as it helps to prevent the spread of Legionnaire's Disease by not introducing oxygen into the water stream. The laminar flow control narrows the stream of water, but allows pressure to remain constant.

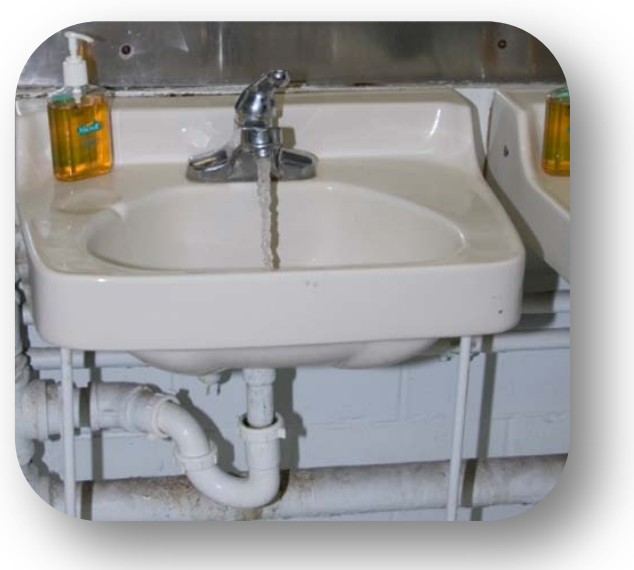

Figure 5.7. Typical Y-12 Lavatory Faucet

\section{Existing Conditions}

Two general types of faucets were identified during the walkthrough inspections. Approximately $80 \%(1,163)$ of the faucets identified are typical threaded faucets that contain their original 2.2 gpm, or higher, aerators, as shown in Figure 5.7.

The additional 20\% (291) of faucets identified were older non-threaded faucets. Many of these exhibit flow rates in excess of $3.5 \mathrm{gpm}$, due to lack of restriction on the faucet spigot. Faucets of this type will require full replacement in order to reduce flow. 


\section{Proposed Recommendations}

In addition to water and sewer consumption savings, high efficiency faucet ends also reduce the amount of domestic hot water (DHW) consumed, therefore reducing energy consumption required to heat the DHW. Faucet retrofits, including restrictors, are typically a low-cost item that will yield a large amount of savings, and often present the quickest paybacks in any conservation project.

All lavatories are recommended for retrofit with 0.5 gpm aerators. Lavatories that are incapable of being retrofit with flow controls, as well as those that have leaks or are damaged, should be replaced with newer threaded faucets and 0.5 gpm aerators. Wash basin replacement is recommended only as necessary, where new faucets will not fit the existing basin cutouts.

All kitchen and laboratory style faucets are recommended for retrofit with 1.0 gpm laminar flow controls. Exceptions to this are laboratory sinks that currently contain chem spouts, and commercial deep-well kitchen sinks that are used for filling of basins only (i.e., three-sink dishwashing stations).

Table 5.5 provides a cost/savings summary for the recommended faucet improvements.

Table 5.5. Faucets Cost and Savings Detail

\begin{tabular}{|c|c|c|c|c|c|c|c|c|c|}
\hline WCM \# & WCM Description & Est. Count & $\begin{array}{c}\text { Est. Total } \\
\text { Water / Sewer } \\
\text { Savings } \\
\text { (gal/yr) }\end{array}$ & $\begin{array}{c}\text { Est. Total } \\
\text { Water / } \\
\text { Sewer } \\
\text { Savings } \\
\text { (\$\$\$yr) }\end{array}$ & $\begin{array}{c}\text { Est. Total } \\
\text { Energy } \\
\text { Savings } \\
\text { (kbtu/yr) }\end{array}$ & $\begin{array}{c}\text { Est. Total } \\
\text { Energy } \\
\text { Savings } \\
\text { (\$\$/yr) }\end{array}$ & $\begin{array}{l}\text { Est. Total } \\
\text { Annual } \\
\text { Savings } \\
\text { (\$\$/yr) }\end{array}$ & $\begin{array}{c}\text { Est. Total } \\
\text { Installed } \\
\text { Cost } \\
\text { (\$\$) }\end{array}$ & $\begin{array}{c}\text { Overall } \\
\text { Simple } \\
\text { Payback } \\
\text { (yrs) }\end{array}$ \\
\hline 3 & \begin{tabular}{|l} 
Install faucet restrictors \\
(0.5 gpm lavatory, $1.0 \mathrm{gpm}$ kitchen/lab)
\end{tabular} & 1,454 & $1,602,640$ & $\$ 17,148$ & 273,256 & $\$ 1,966$ & $\$ 19,115$ & $\$ 87,284$ & 4.57 \\
\hline
\end{tabular}

\subsubsection{Showerheads}

\section{Equipment Summary}

Standard showerheads on the market currently cannot consume more than 2.5 gpm at 80 psi. Efficient showerheads available today range between $1.0 \mathrm{gpm}$ and $2.0 \mathrm{gpm}$. There is a fairly new pressure-compensating showerhead on the market that effectively reduces the flow of water to $1.5 \mathrm{gpm}$, while maintaining an acceptable pressure from the head. One of the largest complaints of early model "low-flow" showerheads was that pressure was reduced so much, it took twice as long to bathe, thereby eliminating any conservation or savings opportunity. The new pressure-compensating technology eliminates the low pressure problems by drawing in air from the perimeter of the showerhead in order to boost the force of the shower spray. The majority of existing showerheads can be replaced with these pressure-compensating showerheads. 


\section{Existing Conditions}

The majority of showerheads that were identified during site walkthroughs are located in the change houses. Additional showers are located sporadically throughout the complex. In general, all of the showerheads examined are traditional-type heads, mounted to a threaded shower supply post, as shown in Figure 5.8. A few of the showers identified did contain institutional-type, wall-mounted head/nozzles. Nearly $100 \%$ of these fixtures were found to have high flow rates in excess of 2.5 $3.0 \mathrm{gpm}$. The only showerheads that were found to have lower flow rates appeared to be in poor condition, indicating that either debris clogs or failed gaskets were causing the lower flow.

Shower usage patterns were determined through interviews with Y-12 staff during the site walkthrough. In typical workplace

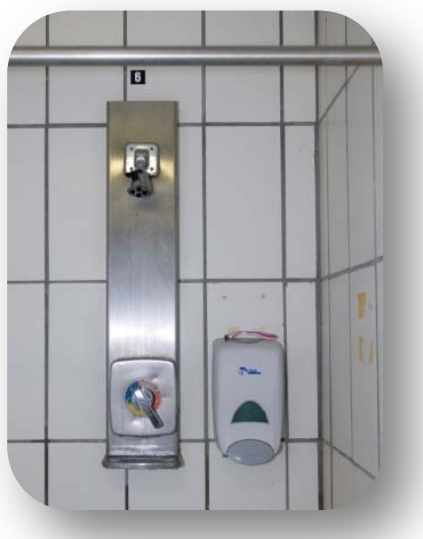

Figure 5.8. Typical Change House Showerhead environments, shower usage is generally minimal. At Y-12, however, nearly $55-60 \%$ of all employees use the showers regularly at the end of their shifts. Shower consumption accounts for a significant portion of domestic plumbing water usage.

\section{Proposed Recommendations}

Installation of low-flow, pressure-compensating $1.5 \mathrm{gpm}$ showerheads is recommended throughout the Y-12 facilities. Both traditional and institutional models are available. Since the change house fixtures are the most frequently used showers at the facility, they will provide the greatest savings impact. The showers located sporadically throughout the complex are still recommended for retrofit, however, because showerheads will pay for themselves after 125 uses. It should be noted that considering approximately $80 \%$ of the water used in a shower is heated (based on $120^{\circ} \mathrm{F}$ DHW temperature setting), a considerable amount of energy savings reduction will be achieved through efficiency retrofits.

Table 5.6 provides a cost/savings summary for the recommended showerhead improvements.

Table 5.6. Showerhead Cost and Savings Detail

\begin{tabular}{|c|c|c|c|c|c|c|c|c|c|}
\hline WCM \# & WCM Description & Est. Count & $\begin{array}{c}\text { Est. Total } \\
\text { Water / Sewer } \\
\text { Savings } \\
\text { (gal/yr) }\end{array}$ & $\begin{array}{c}\text { Est. Total } \\
\text { Water / } \\
\text { Sewer } \\
\text { Savings } \\
\text { (\$\$\$ /yr) }\end{array}$ & $\begin{array}{l}\text { Est. Total } \\
\text { Energy } \\
\text { Savings } \\
\text { (kbtu/yr) }\end{array}$ & $\begin{array}{c}\text { Est. Total } \\
\text { Energy } \\
\text { Savings } \\
\text { (\$\$/yr) }\end{array}$ & $\begin{array}{c}\text { Est. Total } \\
\text { Annual } \\
\text { Savings } \\
\text { (\$\$/yr) }\end{array}$ & $\begin{array}{l}\text { Est. Total } \\
\text { Installed } \\
\text { Cost } \\
(\$ \$)\end{array}$ & $\begin{array}{c}\text { Overall } \\
\text { Simple } \\
\text { Payback } \\
\text { (yrs) }\end{array}$ \\
\hline 4 & $\begin{array}{l}\text { Install } 1.5 \mathrm{gpm} \text { low-flow pressure } \\
\text { compensating showerheads }\end{array}$ & 503 & $9,322,560$ & $\$ 99,751$ & $4,034,122$ & $\$ 29,030$ & $\$ 128,781$ & $\$ 10,066$ & 0.08 \\
\hline
\end{tabular}




\subsection{Commercial Kitchen Water-Using Equipment}

Commercial kitchen equipment, with the exception of ice machines, was identified in the JCC only. Therefore, all discussion of equipment in this section relates to the equipment that was identified in the JCC kitchen. It should be noted that there is a "canteen" in Building 9113 where lunch is served daily. All food that served at the Building 9113 canteen is prepared at the JCC kitchen, which is included in the total water use estimates presented below. Also note that the section pertaining to ice machines does include additional information for machines that are located sporadically throughout the Y-12 Complex.

Table 5.7 provides a cost/savings summary for the recommended kitchen equipment improvements.

Table 5.7. Kitchen Equipment Cost and Savings Summary

\begin{tabular}{|c|c|c|c|c|c|c|c|c|c|}
\hline WCM \# & WCM Description & Est. Count & $\begin{array}{c}\text { Est. Total } \\
\text { Water / Sewer } \\
\text { Savings } \\
\text { (gal/yr) }\end{array}$ & $\begin{array}{c}\text { Est. Total } \\
\text { Water / } \\
\text { Sewer } \\
\text { Savings } \\
\text { (\$\$\$yr) }\end{array}$ & $\begin{array}{c}\text { Est. Total } \\
\text { Energy } \\
\text { Savings } \\
\text { (kbtu/yr) }\end{array}$ & $\begin{array}{c}\text { Est. Total } \\
\text { Energy } \\
\text { Savings } \\
\text { (\$\$/yr) }\end{array}$ & $\begin{array}{c}\text { Est. Total } \\
\text { Annual } \\
\text { Savings } \\
\text { (\$\$/yr) }\end{array}$ & $\begin{array}{l}\text { Est. Total } \\
\text { Installed Cost } \\
\text { (\$\$) }\end{array}$ & $\begin{array}{c}\text { Overall } \\
\text { Simple } \\
\text { Payback } \\
\text { (yrs) }\end{array}$ \\
\hline \multicolumn{2}{|c|}{ Kitchen Equipment Upgrades TOTAL } & & $1,363,149$ & $\$ 14,586$ & 464,364 & $\$ 16,112$ & $\$ 30,698$ & $\$ 158,388$ & 5.16 \\
\hline
\end{tabular}

\section{Technical Approach and Calculation Methodology}

Usage calculations for all kitchen equipment follow a similar calculation pattern. Consumption rates were obtained through manufacturer's specifications for existing equipment, or through onsite measurement of flow. Usage patterns were obtained through interviews with kitchen staff regarding the operation times of various equipment. Essentially, current consumption rates multiplied by current usage patterns generates the baseline water and energy consumption of kitchen equipment. Future consumption rates multiplied by future usage patterns generates the future water and energy consumption of the proposed retrofits/replacements. Baseline consumption minus future consumption equals savings generated for each of the kitchen equipment measures recommended below. Please refer to Appendix A that provides the assumptions used in these calculations.

\subsubsection{Dish Machines}

\section{Equipment Summary}

Many commercial dish machines use far more water than necessary for completing the wash cycle. Furthermore, the water supplied is heated by the DHW system, and then again by booster heaters located at the dish machine. By reducing water consumption on a dish machine, a subsequent large energy savings is realized. Most often, it requires a full dish machine replacement in order to achieve these savings. However, depending on current machine 
specifications and settings, an in-line restrictor can be installed to match the manufacturer's recommended water flow rate for the machine.

\section{Existing Conditions}

The dish machine located in the JCC kitchen, shown in Figure 5.9, is a Stero Corp. dualcompartment conveyor-type machine, model number STPCW-14. According to manufacturer's specifications, this machine is able to process 351 racks per hour. Although the dish machine is fairly new, its water and energy consumption is at the high end of the range for typical dish machines of this type. The flow rate of the machine was found to be $4.45 \mathrm{gpm}$. The water supplied to the machine is first heated through the

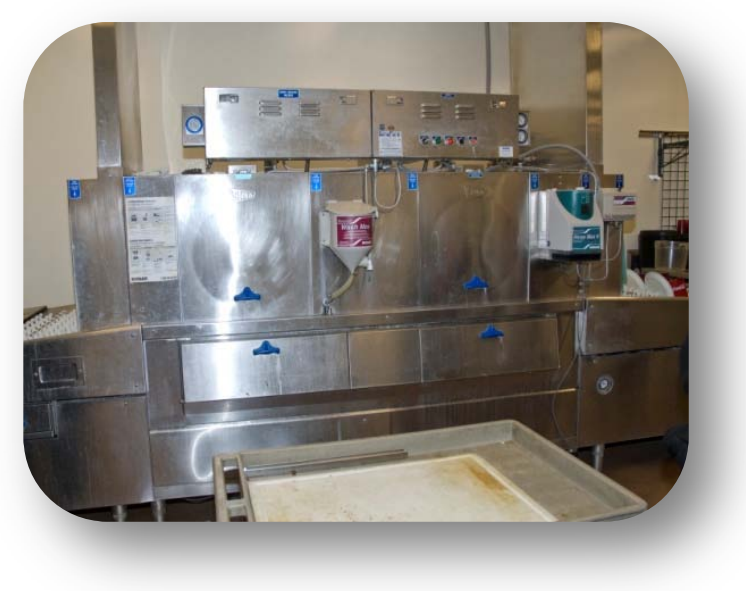

Figure 5.9. Jack Case Center Dish Machine DHW system, then boosted to $180^{\circ} \mathrm{F}$ through the electric booster incorporated in the machine itself. This high temperature is required for sanitization purposes. Based on interviews with staff, the machine is estimated to run for a total of 5 hours per day (although actual run time is broken into smaller segments), 199 days per year.

\section{Proposed Recommendations}

The water-assessment team recommends replacing the existing dish machine with a new high efficiency and low water-use machine that uses a system that recycles rinse water for use in the next wash cycle. The comparable model uses only $2.1 \mathrm{gpm}$, and is still able to process 342 racks per hour. It is recommended that the new system incorporates low water-use spray nozzles and re-use of final rinse and wash water. Essentially, water is supplied to the machine at the final rinse stage only, and flows backwards through the wash and pre-wash compartments. Not only will the amount of water be reduced with these new machines, but a large energy savings will be achieved due to a reduced thermal load.

Table 5.8 provides a cost/savings summary for the recommended dish machine improvements.

Table 5.8. Dish Machine Cost and Savings Detail

\begin{tabular}{|c|c|c|c|c|c|c|c|c|c|}
\hline WCM \# & WCM Description & Est. Count & \begin{tabular}{|c|} 
Est. Total \\
Water / Sewer \\
Savings \\
(gal/yr)
\end{tabular} & $\begin{array}{l}\text { Est. Total } \\
\text { Water / } \\
\text { Sewer } \\
\text { Savings } \\
\text { (\$\$/yr) }\end{array}$ & $\begin{array}{c}\text { Est. Total } \\
\text { Energy } \\
\text { Savings } \\
\text { (kbtu/yr) }\end{array}$ & $\begin{array}{c}\text { Est. Total } \\
\text { Energy } \\
\text { Savings } \\
(\$ \$ / y r)\end{array}$ & $\begin{array}{c}\text { Est. Total } \\
\text { Annual } \\
\text { Savings } \\
\text { (\$\$/yr) }\end{array}$ & $\begin{array}{c}\text { Est. Total } \\
\text { Installed Cost } \\
\text { (\$\$) }\end{array}$ & $\begin{array}{c}\text { Overall } \\
\text { Simple } \\
\text { Payback } \\
\text { (yrs) }\end{array}$ \\
\hline 5 & $\begin{array}{l}\text { Install high efficiency dish machine with Opti- } \\
\text { Rinse technology }\end{array}$ & 1 & 124,800 & $\$ 1,335$ & 149,979 & $\$ 11,606$ & $\$ 12,941$ & $\$ 71,066$ & 5.49 \\
\hline
\end{tabular}




\subsubsection{Garbage Disposals}

\section{Equipment Summary}

Often, garbage disposals, pot washers, and pulpers all require water during the grinding process. Many times, the water supply exceeds what is needed per manufacturers' recommended specs. An in-line flow restrictor can be installed to reduce the flow of nozzle consumption.

\section{Existing Conditions}

The garbage disposal identified at the JCC kitchen is an ISE-1000 heavy commercial garbage disposal. The disposal is fed from a garbage trough system that contains two water supply nozzles with estimated flow rates of $5.0 \mathrm{gpm}$. Manufacturers' specifications require that only $4.0 \mathrm{gpm}$ be supplied to the disposal during the grinding process. Interviews with facility staff indicated that the disposal system experiences a total runtime of 3 hours per day (although actual run time is broken into smaller segments), 199 days per year.

\section{Proposed Recommendations}

It is recommended that in-line flow restrictors are installed to limit the flow of water through the wash basin nozzles to $3.0 \mathrm{gpm}$ each, for a total supply of $6.0 \mathrm{gpm}$ to the disposal grinder. This flow rate is within the manufacturer's specifications for the disposal.

Table 5.9 provides a cost/savings summary for the recommended garbage disposal improvements.

Table 5.9. Garbage Disposal Cost and Savings Detail

\begin{tabular}{|c|c|c|c|c|c|c|c|c|c|}
\hline WCM \# & WCM Description & Est. Count & \begin{tabular}{|c|} 
Est. Total \\
Water / Sewer \\
Savings \\
(gal/yr)
\end{tabular} & $\begin{array}{l}\text { Est. Total } \\
\text { Water/ } \\
\text { Sewer } \\
\text { Savings } \\
\text { (\$\$/yr) }\end{array}$ & $\begin{array}{l}\text { Est. Total } \\
\text { Energy } \\
\text { Savings } \\
\text { (kbtu/yr) }\end{array}$ & $\begin{array}{c}\text { Est. Total } \\
\text { Energy } \\
\text { Savings } \\
(\$ \$ / y r)\end{array}$ & $\begin{array}{l}\text { Est. Total } \\
\text { Annual } \\
\text { Savings } \\
\text { (\$\$ } \$ \text { yr) }\end{array}$ & $\begin{array}{l}\text { Est. Total } \\
\text { Installed Cost } \\
\text { (\$\$\$) }\end{array}$ & $\begin{array}{c}\text { Overall } \\
\text { Simple } \\
\text { Payback } \\
\text { (yrs) }\end{array}$ \\
\hline 6 & $\begin{array}{l}\text { Install in-line flow restrictors on garbage } \\
\text { disposal nozzle supply lines }\end{array}$ & 1 & 149,760 & $\$ 1,602$ & 0 & $\$ 0$ & $\$ 1,602$ & $\$ 2,036$ & 1.27 \\
\hline
\end{tabular}

\subsubsection{Tray Conveyors}

\section{Equipment Summary}

Tray conveyors are used to move dirty trays and dishes from a drop-off point into the dish room. Often, these conveyor systems are equipped with spray nozzles or garbage troughs that allow for preliminary removal of food debris and/or trash. In many cases, the conveyors operate regardless of the presence of dirty trays or dishes, which can lead to a significant waste of water. Two reduction opportunities are available for these types of systems. First, in-line flow restrictors can be installed on the spray nozzle supply lines to limit the flow of water while the conveyor is operating. Second, timers can be installed that will limit the operation time of the conveyor, and completely shut down the water supply. 


\section{Existing Conditions}

The tray conveyor system that is in use at JCC is a tiered compartment tray conveyor. The conveyor system allows four to five trays to be inserted into each compartment, and operates on a constant circulation from the drop-off point to the dish room collection point. Once inside the dish room, staff members manually remove trays and scrape trash into a garbage trough. Once in the trough, food debris, and trash are moved to a garbage collection point by three water jet nozzles that are piped into the trough. Each of these nozzles exhibits a flow rate in excess of $5.0 \mathrm{gpm}$, for a total of $15.0 \mathrm{gpm}$ for the system. Once at the collection point pictured in Figure 5.10, debris is separated from water through a screen, and the water is discharged to the sanitary sewer lines. Interviews with facility staff indicated that the tray conveyor system experiences a total runtime of 4 hours per day (although actual run time is broken into smaller segments), 199 days per year.

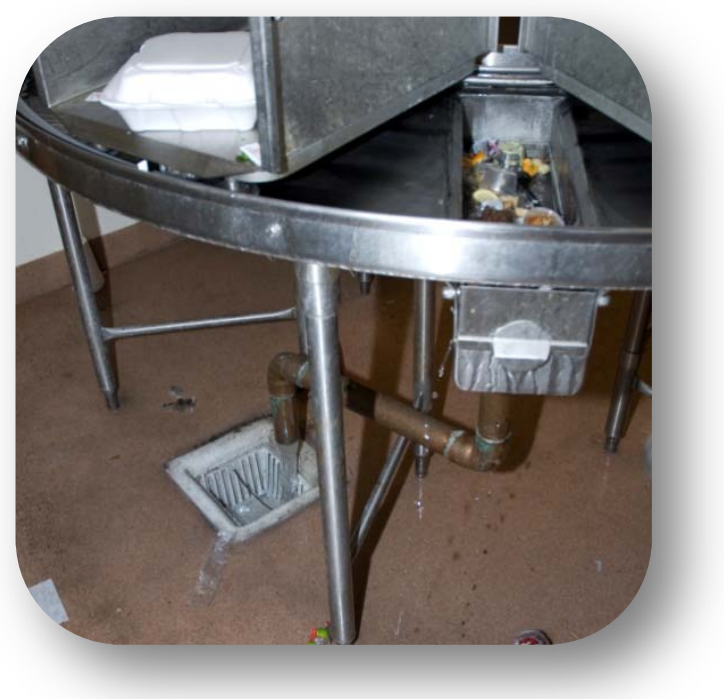

Figure 5.10. Jack Case Center Tray Conveyor System Discharge Location

\section{Proposed Recommendations}

The water-assessment team recommends installing in-line flow restrictors to limit the flow of water through the wash basin nozzles to $3.0 \mathrm{gpm}$ each, for a total supply of 9.0. It is also recommended that timer-based solenoid controls are installed that will limit the amount of runtime for the water supply. Since the water is only used to move debris down the trough, it is estimated that $50 \%$ of the system runtime can be eliminated.

Table 5.10 provides a cost/savings summary for the recommended tray conveyor system improvements.

Table 5.10. Tray Conveyor Cost and Savings Detail

\begin{tabular}{|c|c|c|c|c|c|c|c|c|c|}
\hline WCM \# & WCM Description & Est. Count & \begin{tabular}{|c|} 
Est. Total \\
Water / Sewer \\
Savings \\
(gal/yr)
\end{tabular} & $\begin{array}{l}\text { Est. Total } \\
\text { Water / } \\
\text { Sewer } \\
\text { Savings } \\
\text { (\$\$/yr) }\end{array}$ & $\begin{array}{l}\text { Est. Total } \\
\text { Energy } \\
\text { Savings } \\
\text { (kbtu/yr) }\end{array}$ & $\begin{array}{c}\text { Est. Total } \\
\text { Energy } \\
\text { Savings } \\
\text { (\$\$/yr) }\end{array}$ & $\begin{array}{c}\text { Est. Total } \\
\text { Annual } \\
\text { Savings } \\
\text { (\$\$/yr) }\end{array}$ & $\begin{array}{l}\text { Est. Total } \\
\text { Installed Cost } \\
\text { (\$\$) }\end{array}$ & $\begin{array}{c}\text { Overall } \\
\text { Simple } \\
\text { Payback } \\
\text { (yrs) }\end{array}$ \\
\hline 7 & $\begin{array}{l}\text { Install in-line flow restrictors on tray } \\
\text { conveyor trough nozzle supply lines \& install } \\
\text { timer-based solenoid controls }\end{array}$ & 1 & 524,160 & $\$ 5,609$ & 0 & $\$ 0$ & $\$ 5,609$ & $\$ 4,668$ & 0.83 \\
\hline
\end{tabular}




\subsubsection{Pre-Rinse Sprayers}

\section{Equipment Summary}

Pre-rinse sprayers are often used at pot washing stations to remove food waste. Typically, hot water is used through these sprayers, so a reduction of water flow also provides an energy savings due to the reduction of hot water.

\section{Existing Conditions}

Three pre-rinse sprayers were found in the JCC kitchen area. All are identical to the sprayer pictured in Figure 5.11. The sprayers are used for a variety of kitchen functions including vegetable washing, dishware washing, and general area cleanup. The sprayers exhibited a flow rate of 2.5 gpm or higher. Based on

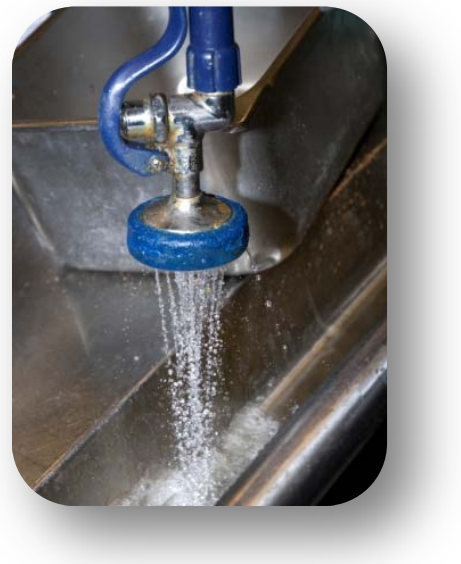

Figure 5.11. Typical Prerinse Sprayer Head in the JCC Kitchen interviews with facility staff, the sprayers are estimated at an average runtime of 2 hours for the two units used for ware washing, and 1.5 hours for the sprayer used at the prep station, 199 days per year.

\section{Proposed Recommendations}

It is recommended that all existing pre-rinse sprayers are replaced with a new $1.28 \mathrm{gpm}$ lowflow high pressure pre-rinse sprayer nozzle.

Table 5.11 provides a cost/savings summary for the recommended pre-rinse sprayer replacements.

Table 5.11. Pre-Rinse Sprayers Cost and Savings Detail

\begin{tabular}{|c|c|c|c|c|c|c|c|c|c|}
\hline WCM \# & WCM Description & Est. Count & $\begin{array}{c}\text { Est. Total } \\
\text { Water / Sewer } \\
\text { Savings } \\
\text { (gal/yr) }\end{array}$ & $\begin{array}{c}\text { Est. Total } \\
\text { Water / } \\
\text { Sewer } \\
\text { Savings } \\
\text { (\$\$/yr) }\end{array}$ & $\begin{array}{l}\text { Est. Total } \\
\text { Energy } \\
\text { Savings } \\
\text { (kbtu/yr) }\end{array}$ & $\begin{array}{l}\text { Est. Total } \\
\text { Energy } \\
\text { Savings } \\
\text { (\$\$/yr) }\end{array}$ & $\begin{array}{l}\text { Est. Total } \\
\text { Annual } \\
\text { Savings } \\
\text { (\$\$/yr) }\end{array}$ & $\begin{array}{c}\text { Est. Total } \\
\text { Installed Cost } \\
\text { (\$\$) }\end{array}$ & $\begin{array}{c}\text { Overall } \\
\text { Simple } \\
\text { Payback } \\
\text { (yrs) }\end{array}$ \\
\hline 8 & Install $1.28 \mathrm{gpm}$ pre-rinse sprayers & 3 & 83,741 & $\$ 896$ & 45,296 & $\$ 261$ & $\$ 1,157$ & $\$ 702$ & 0.61 \\
\hline
\end{tabular}

\subsubsection{Convection Steamers}

\section{Equipment Summary}

Convection steamers use water to create steam in the cooking chamber. Many older models are both water and energy inefficient compared to what is available on today's market. Newer steamers use only $20 \%$ of the water of older models and incorporate a vacuum system to allow steam to be formed at a lower temperature, therefore using much less energy. 


\section{Existing Conditions}

Four convection steamers were found at the JCC kitchen. The steamers are Groen 4-pan electric units. Manufacturer's specifications indicate an average energy usage of $10.9 \mathrm{kWh}$ for every hour of use, and water is consumed by the unit at a rate of 22 gallons per hour. Based on interviews with kitchen staff, operation time of these units was estimated at an average of 5.5 hours per day, 199 days per year.

\section{Proposed Recommendations}

The water-assessment team recommends replacing the convection steamer units with newer connectionless vacuum chamber steamers. This new steamer uses only 1.5 gallons and an average of $1.2 \mathrm{kWh}$ per hour of use. This equates to a $94 \%$ reduction of water use and an $87 \%$ reduction in energy usage.

The reduced water consumption of this unit is due to a fill and drain operation as opposed to a constant feed of water. Essentially this unit is filled with 3 gallons of water and then drained and refilled every two hours. Presumably the water could be re-used all day, but change out is recommended for clean-up purposes. The reduction in energy consumption of this unit is due to incorporation of a vacuum into the steam chamber. A small vacuum pump removes air from the chamber while the cooking process takes place allowing steam to be created at $170^{\circ} \mathrm{F}$, instead of $212^{\circ} \mathrm{F}$. Therefore, much less energy is required to bring water to its boiling point. In addition, the fill and drain method allows the water to hold at a higher temperature; therefore, a smaller temperature difference is achieved for consecutive cook cycles.

As an additional feature of the new steamer units, the vacuum chamber and lower cook temperature allows for faster production times. In addition, many of the nutrients in food remain intact (many proteins are broken down at high heat), allowing for more nutritionally beneficial meals.

Table 5.12 provides a cost/savings summary for the recommended convection steamer improvements.

Table 5.12. Steamer Cost and Savings Detail

\begin{tabular}{|c|c|c|c|c|c|c|c|c|c|}
\hline WCM \# & WCM Description & Est. Count & \begin{tabular}{|c|} 
Est. Total \\
Water / Sewer \\
Savings \\
(gal/yr) \\
\end{tabular} & $\begin{array}{l}\text { Est. Total } \\
\text { Water / } \\
\text { Sewer } \\
\text { Savings } \\
\text { (\$\$/yr) }\end{array}$ & $\begin{array}{l}\text { Est. Total } \\
\text { Energy } \\
\text { Savings } \\
\text { (kbtu/yr) }\end{array}$ & $\begin{array}{l}\text { Est. Total } \\
\text { Energy } \\
\text { Savings } \\
\text { (\$\$\$yr) }\end{array}$ & $\begin{array}{c}\text { Est. Total } \\
\text { Annual } \\
\text { Savings } \\
\text { (\$\$\$yr) }\end{array}$ & $\begin{array}{c}\text { Est. Total } \\
\text { Installed Cost } \\
\text { (\$\$\$) }\end{array}$ & $\begin{array}{c}\text { Overall } \\
\text { Simple } \\
\text { Payback } \\
\text { (yrs) }\end{array}$ \\
\hline 9 & $\begin{array}{l}\text { Replace existing steamers with high } \\
\text { efficiency connectionless steamer units }\end{array}$ & 4 & 93,808 & $\$ 1,004$ & 151,103 & $\$ 2,384$ & $\$ 3,388$ & $\$ 37,485$ & 11.06 \\
\hline
\end{tabular}




\subsubsection{Steam Kettles}

\section{Equipment Summary}

Steam kettles are large pots typically filled with water or other liquid food items. The cooking process is achieved through heat exchange from the kettle's internal boiler or direct steam supply. In general, the water use of these units is a fixed volumetric amount, where the kettle is filled for use and drained when finished. For this reason, water conservation opportunities for steam kettles are limited.

\section{Existing Conditions}

Four steam kettles were identified in the JCC kitchen, and are used primarliy for blanching of vegetables, production of soup, etc. Although the units are used throughout the day, interviews with kitchen staff indicated that the kettles are typically filled for one use throughout the day, and drained at the end of the day. Each kettle is estimated to hold 40 to 50 gallons; however, only two kettles are generally filled with water for blanching or poaching, allowing the other two kettles to be used for soups and sauces, for example.

\section{Proposed Recommendations}

No recommendations can be made at this time. Since steam kettle use is generally a volumetric consumption, as opposed to a constant flow, no conservation opportunities are available.

\subsubsection{Ice Machines}

\section{Equipment Summary}

Ice machines can provide two opportunities for improved water efficiency. First, water-cooled units use once-through fresh water to cool the compressor. Replacing these units with air-cooled ice machine compressors can yield a significant water savings while only slightly increasing electrical energy usage. Second, any ice machine can be retrofitted with a counter flow heat exchanger. This device uses ice melt from the storage bin to pre-cool incoming supply water, so that the compressor uses up to $35 \%$ less energy to create ice.

\section{Existing Conditions}

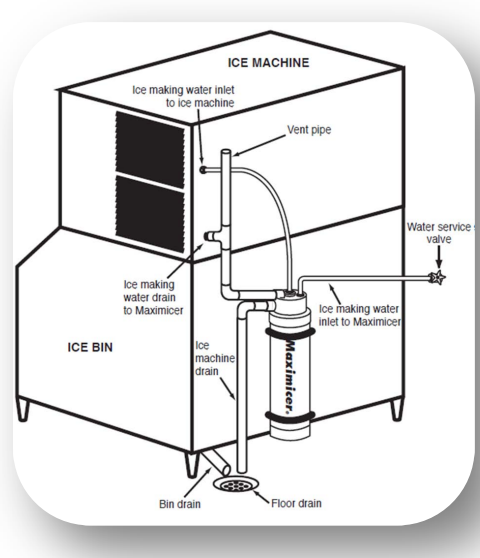

Figure 5.12. Maximicer Installation Schematic

Three large ice machines were identified at the JCC kitchen. Two units are Hoshizaki America 750-lb, air-cooled machines, the third is a Hoshizaki America 1,200-lb, air-cooled machine. Based on interviews with kitchen staff, the machines are used at full capacity, 199 days per year. 
Twenty additional ice machines were identified in buildings throughout the Y-12 Complex. Two machines that were identified are water-cooled units, while the rest are air-cooled. The ice machines range in sizes from $250 \mathrm{lb}$ units to 1,000-lb units. For the purposes of this assessment, an average unit size of $600 \mathrm{lb}$ was used.

\section{Proposed Recommendations}

The water-assessment team recommends replacing the two water-cooled ice machines with air-cooled equivalents. Although a slight increase in energy consumption is incurred with the replacement, the water savings that is generated justifies replacement.

It is also recommended that counter-flow heat exchangers are installed on all existing and newly proposed ice machines. An example model of a counter-flow heat exchanger is a "Maximicer." The Maximicer is installed on the rear of the machine and is connected to the compressor discharge, as shown in Figure 5.12 on the previous page, and/or the ice bin drainage line. The incoming supply water passes through the heat exchanger and is pre-cooled before entering the ice maker. Although this measure will not reduce water consumption, a significant energy savings is achieved by reducing compressor energy. Savings for this portion of the measure is based on a conservative estimate of $24 \%$ energy reduction, as this is the minimum achieved savings on historical projects. In actuality, savings will typically be greater than estimated.

Table 5.13 provides a cost/savings summary for the recommended ice machine improvements.

Table 5.13. Ice Machine Cost and Savings Detail

\begin{tabular}{|c|c|c|c|c|c|c|c|c|c|}
\hline WCM \# & WCM Description & Est. Count & \begin{tabular}{|c|} 
Est. Total \\
Water / Sewer \\
Savings \\
(gal/yr) \\
\end{tabular} & $\begin{array}{c}\text { Est. Total } \\
\text { Water / } \\
\text { Sewer } \\
\text { Savings } \\
\text { (\$\$ } \$ \text { yr) } \\
\end{array}$ & $\begin{array}{c}\text { Est. Total } \\
\text { Energy } \\
\text { Savings } \\
\text { (kbtu/yr) }\end{array}$ & $\begin{array}{c}\text { Est. Total } \\
\text { Energy } \\
\text { Savings } \\
(\$ \$ / y r) \\
\end{array}$ & $\begin{array}{c}\text { Est. Total } \\
\text { Annual } \\
\text { Savings } \\
(\$ \$ \text { yr) } \\
\end{array}$ & $\begin{array}{c}\text { Est. Total } \\
\text { Installed Cost } \\
(\$ \$)\end{array}$ & $\begin{array}{c}\text { Overall } \\
\text { Simple } \\
\text { Payback } \\
\text { (yrs) }\end{array}$ \\
\hline 10 & $\begin{array}{l}\text { Install counter-flow heat exchangers on all } \\
\text { existing and proposed ice machines }\end{array}$ & 23 & 0 & $\$ 0$ & 125,227 & $\$ 1,976$ & $\$ 1,976$ & $\$ 16,431$ & 8.32 \\
\hline 11 & $\begin{array}{l}\text { Replace existing water-cooled ice machines } \\
\text { with air-cooled equivalents }\end{array}$ & 2 & 386,880 & $\$ 4,140$ & $(7,241)$ & (\$114) & $\$ 4,025$ & $\$ 26,000$ & 6.46 \\
\hline
\end{tabular}

\subsubsection{Miscellaneous Kitchen Usage}

Miscellaneous kitchen usage category encompasses all additional water used during meal production. This can include a variety of different uses, such as drinking water, production of soups, baked goods, and other food items, and area cleanup. It is impossible to accurately determine the exact consumption of water used for this category, but studies on kitchen use have shown an average of 4 gallons of water is used per meal served. Based on interviews with kitchen management, an average of 2,680 meals (from breakfast and lunch shifts) are served throughout the day. This equates to 2,230 kgal of water use assigned to the miscellaneous kitchen usage category. 


\subsection{Process Systems/Cooling}

Various experimental, industrial, and manufacturing processes at $\mathrm{Y}-12$ require cooling in order to function properly and maintain life of equipment. Water is a great medium for transferring heat for cooling. For example, this can be achieved by passing water through equipment heat exchangers that will allow heat generated by the various processes to dissipate into the passing water. Three primary systems are capable of achieving this heat sink, and are discussed below.

\section{Technical Approach and Calculation Methodology}

Process consumption was determined through the use of information survey forms provided to Y-12 staff, since the majority of processes were not able to be inspected due to security clearance-related issues. For processes that were included in these surveys, consumption was determined by supply connection size and time of use. Under standard building pressures, water will flow through pipes at 7 feet per second. Based on the various pipe sizes, a gallon per minute flow rate was determined for each process.

Additional consumption for process usage that was not included in the information surveys was estimated based on total plant consumption. Table 5.14 provides a cost/savings summary for the recommended process system improvements.

Table 5.14. Process Cooling Cost and Savings Summary

\begin{tabular}{|c|c|c|c|c|c|c|c|c|c|}
\hline WCM \# & WCM Description & Est. Count & $\begin{array}{c}\text { Est. Total } \\
\text { Water / Sewer } \\
\text { Savings } \\
\text { (gal/yr) }\end{array}$ & $\begin{array}{l}\text { Est. Total } \\
\text { Water / } \\
\text { Sewer } \\
\text { Savings } \\
\text { (\$\$\$yr) }\end{array}$ & $\begin{array}{l}\text { Est. Total } \\
\text { Energy } \\
\text { Savings } \\
\text { (kbtu/yr) }\end{array}$ & $\begin{array}{c}\text { Est. Total } \\
\text { Energy } \\
\text { Savings } \\
\text { (\$\$\$yr) }\end{array}$ & $\begin{array}{c}\text { Est. Total } \\
\text { Annual } \\
\text { Savings } \\
\text { (\$\$ } \$ \text { yr) }\end{array}$ & $\begin{array}{c}\text { Est. Total } \\
\text { Installed Cost } \\
\text { (\$\$) }\end{array}$ & $\begin{array}{c}\text { Overall } \\
\text { Simple } \\
\text { Payback } \\
\text { (yrs) }\end{array}$ \\
\hline & Process Systems Upgrades TOTAL & - & $57,738,123$ & $\$ 76,214$ & 0 & $\$ 0$ & $\$ 76,214$ & $\$ 336,000$ & 4.41 \\
\hline
\end{tabular}

\subsubsection{Process Cooling - Closed Chilled Loop}

\section{Equipment Summary}

Closed-loop chilled water systems provide a recirculating stream of chilled water that can be used to dissipate heat from various plant processes and industrial functions. This method of heat sink is by far the most water efficient, as virtually no water is consumed in the process. Rather, chiller systems distribute chilled water solutions (typically brine, glycol, or chemically enhanced water ranging from $35^{\circ} \mathrm{F}$ to $45^{\circ} \mathrm{F}$ ) via primary and secondary pumps to process heat exchangers. At the heat exchangers, the chilled water absorbs heat from the process, raising the temperature

by $5^{\circ} \mathrm{F}$ to $12^{\circ} \mathrm{F}$. The warmed solution is then returned to a chiller system where compressors chill the solution once again to $35^{\circ} \mathrm{F}$ to $45^{\circ} \mathrm{F}$, before being sent out to the distribution system again. 
Essentially, this is a $100 \%$ recirculated system in which no water is consumed, although minor system losses may occur and the chilled water lines must be refilled with the appropriate solution. The amount of make-up water required for chilled loops is virtually negligible, unless major distribution system leaks are present. Production of chilled water by the chillers is an energy-intensive process, however, where electrical energy is supplied to the chiller compressors in order to super-cool the chilled water solutions.

\section{Existing Conditions}

Although a comprehensive audit of all processes at Y-12 was not conducted due to security clearances required for investigation of the equipment, facility personnel indicated that many of the processes utilize this method of heat sink. This method is the most water efficient way of removing heat, since virtually no water is consumed directly by the process heat exchangers.

\section{Proposed Recommendations}

At this time, no recommendations can be made at the process level for closed chilled-loop systems. Recommendations can be made for the secondary condenser loop that is supplied from the cooling towers to the chiller systems. These recommendations are discussed in Section 5.6 of this water assessment.

\subsubsection{Process Cooling - Recycling Condenser Loop}

\section{Equipment Summary}

Recycling condenser loop systems are considered partially closed systems that also provide a recirculating stream of cool water that can be used to dissipate heat. The condenser water temperature typically ranges from $55^{\circ} \mathrm{F}$ to $85^{\circ} \mathrm{F}$ (depending on wet-bulb air temperature), which does not provide the cooling capacity that chilled water systems provide, but can be used for less heat-intensive process cooling. Condenser loop water that is provided for process cooling is supplied directly from cooling towers via primary and secondary distribution pumps to process heat exchangers. At the heat exchangers, the chilled water absorbs heat from the process raising the temperature by $5^{\circ} \mathrm{F}$ to $12^{\circ} \mathrm{F}$. The warmed condenser water is then returned to the cooling tower where some of the water is evaporated in order to restore the temperature to $55^{\circ} \mathrm{F}$ to $85^{\circ} \mathrm{F}$, before being sent out to the distribution system again.

In a perfect system, $100 \%$ of condenser loop water is returned to the cooling tower, where it is cooled through a mechanical draft and evaporation process. Further details of cooling tower operation and consumption are discussed in a later section of this chapter.

\section{Existing Conditions}

During the course of the walkthrough inspection, major condenser loop return issues were identified. The 9409-18/31 cooling tower systems, which supply condenser water for process cooling to the 9202 and 9203 Development buildings, as well as chiller plant cooling for the 
9767-11 chillers, were found to return only $80 \%$ of the supplied condenser water back to the cooling towers. Likewise, the 9409-23 tower, which supplies process cooling only for the 9212 building, was found to return only $75 \%$ of the supplied condenser water back to the cooling tower.

These are indications of an open loop, where condenser water is discharged to either sanitary sewer or storm sewer drainage systems as opposed to being returned to the tower. This condition is extremely water inefficient since condenser water that is not returned serves essentially as once-through potable water that has previously been evaporated. Under these conditions, approximately $15-20 \%$ of the volume of water that is supplied as make-up to the cooling tower is evaporated before even entering the distribution system, generating a 15-20\% water efficiency reduction immediately.

Figure 5.13 illustrates the discrepancy between supply and return volumes for the 9409-18/31 cooling towers. An average discrepancy of $117 \mathrm{gpm}$ was identified through the use of tandem ultrasonic flow meters.

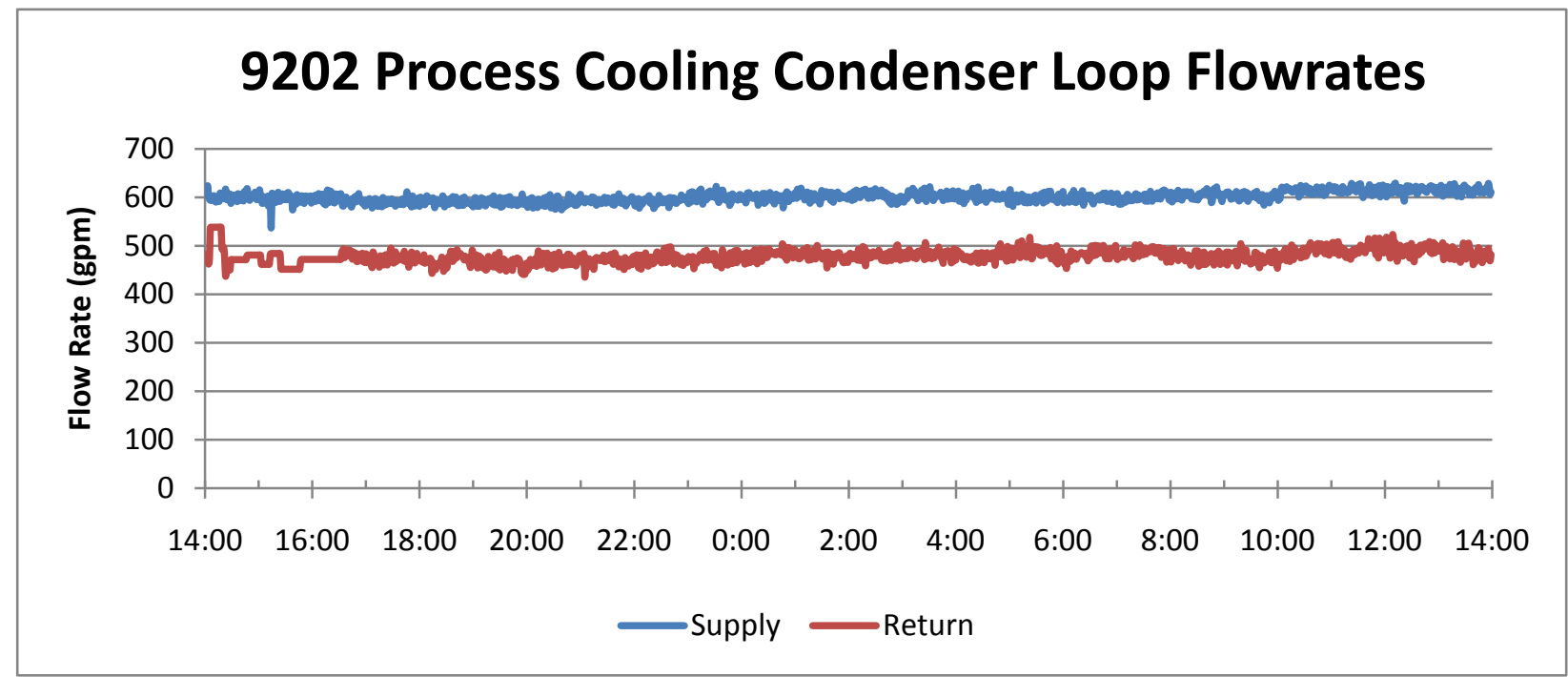

Figure 5.13. Condenser Loop Supply and Return Flow Rate Discrepancy

\section{Proposed Recommendations}

The water-assessment team recommends that a comprehensive internal audit be conducted of all processes connected to the 9409-18/31 process condenser loop or the 9409-23 process condenser loop. Any connections that do not return condenser water to the tower should be repaired, so that all supply water is returned to the cooling tower.

Table 5.15 provides a cost/savings summary for the recommended process system improvements. 
Table 5.15. Condenser Loop Repairs Cost and Savings Detail

\begin{tabular}{|c|c|c|c|c|c|c|c|c|c|}
\hline WCM \# & WCM Description & Est. Count & \begin{tabular}{|c|} 
Est. Total \\
Water / Sewer \\
Savings \\
(gal/yr)
\end{tabular} & $\begin{array}{l}\text { Est. Total } \\
\text { Water / } \\
\text { Sewer } \\
\text { Savings } \\
\text { (\$\$\$yr) }\end{array}$ & $\begin{array}{c}\text { Est. Total } \\
\text { Energy } \\
\text { Savings } \\
\text { (kbtu/yr) }\end{array}$ & $\begin{array}{c}\text { Est. Total } \\
\text { Energy } \\
\text { Savings } \\
\text { (\$\$/yr) }\end{array}$ & $\begin{array}{c}\text { Est. Total } \\
\text { Annual } \\
\text { Savings } \\
\text { (\$\$\$yr) }\end{array}$ & $\begin{array}{l}\text { Est. Total } \\
\text { Installed Cost } \\
\text { (\$\$\$) }\end{array}$ & $\begin{array}{c}\text { Overall } \\
\text { Simple } \\
\text { Payback } \\
\text { (yrs) }\end{array}$ \\
\hline 12 & $\begin{array}{l}\text { Repair condenser loop connections so that all } \\
\text { condenser water is returned to the cooling } \\
\text { towers }\end{array}$ & 12 & $57,738,123$ & $\$ 76,214$ & 0 & $\$ 0$ & $\$ 76,214$ & $\$ 336,000$ & 4.41 \\
\hline
\end{tabular}

\section{Demonstrated Results}

After the water assessment team completed its analysis, staff at Y-12 performed the recommended internal audit to determine if return water was being discharged to either the sanitary sewer or storm drainage. Y-12 accomplished this by placing dye in the cooling tower and tracking where the dye discharged. The dye was confirmed in the sanitary sewer in 7 minutes after being introduced into the cooling tower. Also, Y-12 staff found cooling tower lines in 9202 that were draining directly to the sanitary sewer. These lines were shut off and flow measurements showed a drastic reduction in sanitary sewer flows. It is estimated that by shutting off these lines to the sanitary sewer, there is a reduction in flow of about $154 \mathrm{gpm}$. Because of Y-12's high sanitary sewer rates, this will save the complex approximately \$750,000 annually.

\subsubsection{Once-through Potable Process Water}

\section{Equipment Summary}

Once-through potable process cooling is an open-loop system where potable process water is used for cooling. The potable process water is non-domestic use water that is tapped off of the potable water supply through backflow preventers. This water serves two main purposes: 1) cooling water to dissipate heat produced by or supplied to processes or 2) direct supply water consumed by processes.

\section{Existing Conditions}

At $\mathrm{Y}-12$, for the heat dissipation function, the potable process water passes through the heat exchangers and is discharged to sanitary sewer drains or stormwater drains. The vast majority of this type of potable process water use is discharged to storm sewer drains, and is therefore not subject to sanitary sewer charges. However, some process systems at $\mathrm{Y}-12$ do exist where the discharge is directed to the sanitary sewer lines and incur significant sewer costs. Since the process water does not come in direct contact with any chemicals or contaminants of the process itself, the process water discharge could be directed to the storm sewer system, where it can be dechlorinated and discharged to the East Fork Poplar Creek. No consumption reduction is attainable for this type of consumption without eliminating the process altogether, however, the discharge can be rerouted from sanitary sewer to storm sewer systems in order to eliminate costly sanitary sewer charges. 
Various other laboratory, industrial, and manufacturing processes consume potable process water directly. A wide variety of chemicals and contaminants can be introduced through these process water consumptions, and therefore must be discharged to the sanitary sewer system. No consumption reduction is attainable for this type of consumption without eliminating the process altogether.

\section{Proposed Recommendations}

The water-assessment team recommends two specific measures to be taken to reduce water and/or energy consumption related to processes. First, a comprehensive internal audit of all processes should be conducted to determine the condition of process heat exchangers. Replacement of any older heat exchangers in poor condition can significantly improve the operating efficiency by reducing the amount of potable, condenser, and chilled water required to dissipate the heat. This energy and water consumption reduction is achieved due to the fact that new heat exchangers will transfer heat more readily, and result in a lower cooling load for any of the three cooling systems discussed in this section. No cost/savings analysis can be determined until all equipment is identified, but an estimated 5-7\% water and energy savings can be achieved through these replacements.

The second recommendation is one that is designed only to reduce once-through potable water consumption at the cost of increasing energy consumption. Since potable water is inexpensive relative to other resources, any other type of process cooling would incur higher operating costs. However, if the mission of $\mathrm{Y}-12$ is to strictly reduce water consumption, all once-through potable process cooling systems can be redesigned with supply from either recycling condenser loops or from chilled water loops. Either of these recommendations will require a significant first cost investment for installation of new cooling towers and chiller systems. It should be noted, however, that this category of consumption is the single largest category in the water balance. In order to meet the directives and goals of E.O. 13423 and E.O. 13514, measures of this nature must be taken. No cost/savings analysis can be determined until all equipment is identified.

No recommendations can be made for reduction of water consumed directly by processes without eliminating the process itself.

\subsection{Cooling Towers}

\section{Equipment Summary}

Cooling towers use a partially closed-loop system to dissipate heat from production processes, refrigeration systems, air compressors, and other water-cooled equipment such as induction furnaces, pumps, and presses as well as for space cooling. A cooling tower's primary function is to cool condenser loop water that serves as a heat sink to HVAC, or other equipment processes. As the warmed condenser loop water returns from the heat exchanger location to the cooling tower, where it is dispersed and trickles down over the fill. As the water trickles down, 
it is contacted by ambient air rising through the tower either by natural or forced draft. The ambient air causes a portion of the condenser water to evaporate, effectively reducing the temperature of the condenser water. The cooled condenser water then collects in a basin, where it is then distributed to the various cooling functions attached to the condenser loop.

Through the evaporation process, a portion of the total volume of water in the system is lost to gaseous escape, while the mineral content remains in the condenser water solution that collects in the basin. Once the mineral content in the basin approaches the maximum desired level of conductivity, a portion of the cooling tower must blow-down and be replaced with fresh potable water in order to decrease the conductivity level of the water. The blow-down process is primarily a maintenance procedure designed to maintain the efficiency of the equipment. If mineral content was allowed to go above desired levels, scaling of the equipment would occur, which greatly impedes the efficient operation of the tower, by reducing dispersion and heat transfer during the evaporative cooling process. Scaled heat exchangers have to work much harder to extract the same amount of heat as clean systems because the scale acts as an insulation limiting the heat transfer.

\section{Water Efficiency Management}

There are two vital data requirements to properly manage the water use of a cooling tower: total dissolved solids (TDS) levels and water consumption. Based on our observations from the audit, neither of these data points is regularly used. It is impossible to know the water efficiency of a cooling tower without frequent monitoring of water use and TDS levels of the water. Just because the tower is performing its cooling function adequately does not equate to water efficiency.

The TDS levels of both the input water and the bleed (or blow-down) water should be monitored by use of a conductivity meter ${ }^{1}$ or controller. A controller will both monitor the TDS level and the cooling tower water and can actuate water supply valves and chemical additives to maintain safe levels of TDS and chemical treatment. A sudden increase or decrease in TDS levels can indicate equipment malfunction or contamination of cooling water.

Most of the towers have dedicated water meters for the freshwater input. These meters should be read daily (or more often) to monitor water efficiency and alert the operators to malfunction that can damage the cooling system or cause excessive water use. A sudden increase or decrease in water use can indicate catastrophic failures.

\footnotetext{
${ }^{1}$ Minerals such as calcium, magnesium, carbonate, bicarbonate, iron, and silica can contribute to scaling issues in cooling systems. These and other dissolved minerals should be maintained at desired thresholds by proper conductivity monitoring.
} 


\section{Cycles of Concentration and Water Efficiency}

Cooling tower water efficiency is traditionally expressed by Cycles of Concentration (COC), measured by input water TDS levels compared to blow-down water TDS levels. For example, where the source water for the tower has TDS of $100 \mathrm{ppm}$, and the blow-down water has TDS of $300 \mathrm{ppm}$; the COC value is $3(300 / 100)$.

The water efficiency goal is to maximize the COC, allowing the cooling tower water to be recirculated and reused to the highest TDS level possible without damaging the equipment, before being dumped. If the TDS levels become too high, the minerals will precipitate out of solution and attach to the surfaces; a problem referred to as scaling. Scaling will decrease heat transfer efficiency, clog the equipment and could eventually cause catastrophic failures. In addition, high mineral content contributes to corrosion of the system metallurgy. Corrosion rates will vary depending on the different metallurgies throughout each system, but typically occurs where temperatures are elevated and flow rates are excessively high, or where stagnant low-flow conditions occur.

Because the freshwater input varies at each location (and sometimes seasonally), the preferred COC target is different for each site. Even the maximum TDS level varies based on the type of cooling tower, the type of equipment cooled, the type of materials the water comes in contact with, and the temperature of both the water and the equipment. As a general rule of thumb, the TDS levels should not exceed 900 ppm, but there are many exceptions.

Table 5.16 provides a cost/savings summary for the recommended cooling tower improvements as described in more detail below.

Table 5.16. Cooling Tower Upgrades Cost and Savings Summary

\begin{tabular}{|c|c|c|c|c|c|c|c|c|c|}
\hline WCM \# & WCM Description & Est. Count & $\begin{array}{c}\text { Est. Total } \\
\text { Water / Sewer } \\
\text { Savings } \\
\text { (gal/yr) }\end{array}$ & $\begin{array}{l}\text { Est. Total } \\
\text { Water / } \\
\text { Sewer } \\
\text { Savings } \\
\text { (\$\$\$yr) }\end{array}$ & $\begin{array}{l}\text { Est. Total } \\
\text { Energy } \\
\text { Savings } \\
\text { (kbtu/yr) }\end{array}$ & $\begin{array}{c}\text { Est. Total } \\
\text { Energy } \\
\text { Savings } \\
\text { (\$\$/yr) }\end{array}$ & $\begin{array}{l}\text { Est. Total } \\
\text { Annual } \\
\text { Savings } \\
(\$ \$ / y r)\end{array}$ & $\begin{array}{l}\text { Est. Total } \\
\text { Installed Cost } \\
\text { (\$\$) }\end{array}$ & $\begin{array}{c}\text { Overall } \\
\text { Simple } \\
\text { Payback } \\
\text { (yrs) }\end{array}$ \\
\hline & Cooling Tower Upgrades TOTAL & & $71,964,002$ & $\$ 94,992$ & $9,250,645$ & $\$ 145,956$ & $\$ 240,948$ & $\$ 2,881,120$ & 11.96 \\
\hline
\end{tabular}

\section{Technical Approach and Calculation Methodology}

Cooling tower consumption was provided from some of the systems that currently contain make-up sub-meters. This consumption was compared to typical consumption ranges for similar size towers to determine any deficiencies. Savings opportunities were provided by sample manufacturers for each of the proposed improvements. 


\section{Existing Conditions}

The Y-12 Complex uses towers that are dedicated for condenser loop process cooling, mentioned previously, as well as towers that serve HVAC systems and process cooling.

The following is a list of cooling towers currently in operation at the Y-12 Complex.

- 9409-02 - Supply to 9767-8 Chiller Systems

- 9409-10 - Supply to 9767-4/4E Chiller Systems, Process Cooling for 9204-2

- 9409-13 - Supply to 9767-13 Chiller Systems, Process Cooling for 9201-4, 9201-5N/W

- 9409-18/31 - Supply to 9767-11 Chiller Systems, Process Cooling for 9202, 9203

- 9409-22, 22E, 24, 24E - Supply to 9767-10 Chiller Systems, Process Cooling for HEUMF

- 9409-23 - Process Cooling for 9212

- 9409-26W - Process Cooling for 9215, 9998

- 9409-30 - Supply to 9767-12 Chiller Systems

- 9409-34 - Process Cooling for 9727-4 air compressors

\section{9-2 Cooling Towers}

The 9409-2 cooling tower system contains four cells that have 1,250-ton chilling capacity per cell that share one collection basin. The fill tubes have recently been cleaned, and the tower appears to be in fair-to-good condition. The towers serve as a recycling condenser loop for the 9767-8 chiller systems. Make-up water is supplied to the system via a 4-inch make-up water feed line with a solenoid valve actuated by a basin level sensor. The make-up line does contain a bypass in the event of solenoid valve failure. Blow-down is achieved through a 2 -inch line that has been manually opened to discharge at a constant rate. The system currently contains no meters for tracking make-up or blow-down consumption.

\section{9-10 Cooling Towers}

The 9409-10 cooling tower system contains four cells with 925-ton capacity that share one collection basin. The fill tubes have a moderate amount of scale and fouling, and some minor basin leakage was identified. The towers serve as a recycling condenser loop for the 9767-4/4E chiller systems, as well as process cooling for 9204-2. Make-up water is supplied to the system via 3-inch make-up water feed line with a solenoid valve actuated by a basin level sensor. The make-up line does contain a bypass in the event of solenoid valve failure. Blow-down is achieved through a 2-inch line that has been manually opened to discharge at a constant rate. The system currently contains simple analog meters for tracking make-up consumption. Blowdown consumption is not monitored.

\section{9-13 Cooling Towers}

The 9409-13 cooling tower system contains seven 1,100-ton cells and one 1,400-ton cell that share one collection basin. The fill tubes have a moderate amount of scale and fouling, and some 
sludge was identified in the cooling tower basin. The towers serve as a recycling condenser loop for the 9767-13 chiller systems, as well as process cooling for 9201-5,5N,5W and 9201-4. Make-up water is supplied to the system via two independent 3-inch make-up water feed lines with solenoid valve actuated by a basin level sensor. The second make-up line is set at a lower basin level, so is only used when needed. The make-up lines do contain a bypass in the event of solenoid valve failure. Blow-down is achieved through a single 1-inch line that has been manually opened to discharge at a constant rate. The system currently contains simple analog meters for tracking make-up consumption. Blow-down consumption is not monitored.

\section{9-18/31 Cooling Towers}

The 9409-18/31 cooling tower system contains two separate 1,200-ton cells that each utilize their own collection basin. The 9409-31 tower is a new unit that had not been brought online yet at the time of the site walkthroughs. The 9409-18 tower was found to have a moderate amount of scale and fouling. The towers serve as a recycling condenser loop for the 9767-11 chiller systems, as well as process cooling for 9202 and 9203. Make-up water is supplied to the system via two independent 3-inch make-up water feed lines with a solenoid valve actuated by a basin level sensor. The make-up lines do contain a bypass in the event of solenoid valve failure. Blowdown is achieved through two independent $1 \frac{1}{2}$-inch lines that have been manually opened to discharge at a constant rate. The system currently contains simple analog meters for tracking make-up consumption. Blow-

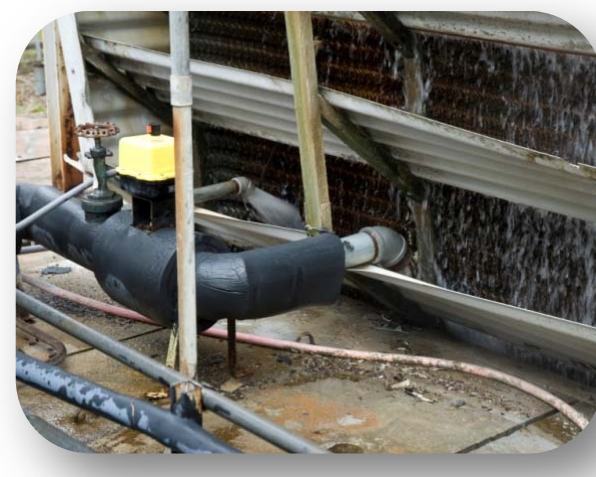

Figure 5.14. 9409-18 Cooling Tower with Constant Flow Bypass down consumption is not monitored.

This tower system, mentioned previously in Section 5.5.2, only returns $80 \%$ of the water supplied for process cooling. For this reason, the entire basin can be drained in approximately 2 hours, which has caused the solenoid valve to fail. The bypass has been opened to full capacity at approximately $160 \mathrm{gpm}$, as shown in Figure 5.14. Since only $107 \mathrm{gpm}$ is lost on average to improper loop connections, the basin experiences an overflow of approximately $53 \mathrm{gpm}$.

\section{9-22, 22E, 24, 24E Cooling Towers}

The 9409-22, 22E, 24 cooling tower system contains two 1,400 ton cells, two 1,200-ton cells, and five 1,200-ton cells that share one collection basin. The 9409-24E cooling tower contains one additional 1,200-ton cell and its own collection basin. The fill tubes have a large amount of scale and fouling, and some sludge was identified in the cooling tower basin. The towers serve as a recycling condenser loop for the 9767-10 chiller systems, as well as process cooling for the Highly Enriched Uranium Materials Facility (HEUMF) building. Make-up water is supplied to the system via two independent 3-inch make-up water feed lines with a solenoid valve actuated by a basin level sensor. The make-up lines do contain a bypass in the event of solenoid valve 
failure. Blow-down is achieved through two independent $1 \frac{1}{2}$-inch lines that have been manually opened to discharge at a constant rate. The system currently contains simple analog meters for tracking make-up consumption. Blow-down consumption is not monitored.

\section{9-23 Cooling Towers}

The 9409-23 cooling tower system contains four 400-ton cells that share one collection basin. The fill tubes are relatively clean and appear to be in good condition. The towers serve as a recycling condenser loop for process cooling of the 9212 building. Make-up water is supplied to the system via 3-inch make-up water feed line with a solenoid valve actuated by a basin level sensor. The make-up line does contain a bypass in the event of solenoid valve failure. Blowdown is achieved through a $1 \frac{1}{2}$-inch line that has been manually opened to discharge at a constant rate. The system currently contains simple analog meters for tracking make-up consumption. Blow-down consumption is not monitored.

This tower system, mentioned previously in Section 5.5.2, only returns $75 \%$ of the water supplied for process cooling. Solenoid valve failure has not occurred at this point, the but makeup supply valve was observed to fail on three separate occasions during a 30-minute inspection of the equipment. Based on this observation, and relatively low meter readings, it is expected that the sub-meter installed on the make-up supply line has failed.

\section{9-26W Cooling Towers}

The 9409-26W cooling tower system contains four 625-ton cells that share one collection basin. The fill tubes were observed to have a significant amount of scale and fouling, in addition to a large amount of sludge accumulation in the collection basin. The circulation pumps associated with this tower were observed to have persistent leaks of 3-5 gpm. The towers serve as a recycling condenser loop for process cooling for 9215 and 9998. Make-up water is supplied to the system via 3-inch make-up water feed line with a solenoid valve actuated by a basin-level sensor. The make-up line does contain a bypass in the event of solenoid valve failure. Blowdown is achieved through a $1 \frac{1}{2}$-inch line that has been manually opened to discharge at a constant rate. The system currently contains simple analog meters for tracking make-up consumption. Blow-down consumption is not monitored.

\section{9-30 Cooling Towers}

The 9409-30 cooling tower system contains two 300-ton cells that share one collection basin. The fill tubes were observed to be very clean, primarily as a result of ozonation pre-treatment of the make-up water. The towers serve as a recycling condenser loop for process cooling for 9215 and 9998. Make-up water is supplied to the system via 2-inch make-up water feed line with solenoid valve actuated by a basin level sensor. The make-up line does contain a bypass in the event of solenoid valve failure. Blow-down is achieved through a 1-inch line that has been manually opened to discharge at a constant rate. The system currently does not contain meters for tracking consumption. 


\section{9-34 Cooling Towers}

The 9409-34 cooling tower system contains one 200-ton cell and single collection basin. At the time of walkthrough inspections, this tower was offline for maintenance and cleaning. The tower serves as a recycling condenser loop for process cooling for 9727-4 air compressor plant. Make-up water is supplied to the system via 3-inch make-up water feed line with a solenoid valve actuated by a basin level sensor. The make-up line does contain a bypass in the event of solenoid valve failure. Blow-down is achieved through a 2-inch line that has been manually opened to discharge at a constant rate. The system currently contains simple analog meters for tracking make-up consumption. Blow-down consumption is not monitored.

\section{Proposed Recommendations}

The water-assessment team recommends three specific measures related to improving cooling tower efficiency. First, advanced sub-metering systems should be installed on both make-up and blow-down lines in order to provide accurate data regarding cooling tower performance. Although no savings is attributed directly to metering, this measure is essential for proper monitoring and maintenance of the towers. Fluctuations in water consumption can indicate functional discrepancies of the tower, and assist in preventative maintenance and/or quick repair of any problems that can occur.

Second, it is recommended that conductivity controllers are installed and properly maintained on each of the cooling tower systems. These controllers will regulate blow-down, and eliminate constant discharge. Allowing TDS levels to build to maximum desired level, then completing the blow-down cycle is the most efficient way for cooling towers to operate.

Third, it is recommended that side-stream filtration systems are installed on each of the cooling tower systems. Side-stream filtration will remove content such as sediment, suspended particles, silt, and organics from the condenser water allowing for higher cycles of concentration and improved operation of the cooling towers. This measure reduces not only water consumption by reducing the amount of blow-down needed, but also significant energy savings reducing scale and by limiting suspended materials that contribute to fouling and provide food for biological growth. Hydrodynamic cavitation systems can be used as an alternate to sidestream technology. Essentially, the systems achieve the same savings result for approximately the same investment.

Table 5.17 provides a cost/savings summary for the recommended cooling tower improvements. 
Table 5.17. Cooling Tower Upgrades Cost and Savings Detail

\begin{tabular}{|c|c|c|c|c|c|c|c|c|c|}
\hline WCM \# & WCM Description & Est. Count & $\begin{array}{c}\text { Est. Total } \\
\text { Water / Sewer } \\
\text { Savings } \\
\text { (gal/yr) }\end{array}$ & $\begin{array}{l}\text { Est. Total } \\
\text { Water / } \\
\text { Sewer } \\
\text { Savings } \\
\text { (\$\$/yr) }\end{array}$ & $\begin{array}{l}\text { Est. Total } \\
\text { Energy } \\
\text { Savings } \\
\text { (kbtu/yr) }\end{array}$ & $\begin{array}{l}\text { Est. Total } \\
\text { Energy } \\
\text { Savings } \\
\text { (\$\$/yr) }\end{array}$ & $\begin{array}{l}\text { Est. Total } \\
\text { Annual } \\
\text { Savings } \\
\text { (\$\$/yr) }\end{array}$ & $\begin{array}{c}\text { Est. Total } \\
\text { Installed Cost } \\
\text { (\$\$) }\end{array}$ & $\begin{array}{c}\text { Overall } \\
\text { Simple } \\
\text { Payback } \\
\text { (yrs) }\end{array}$ \\
\hline 13 & Install advanced sub-metering systems & 9 & 0 & $\$ 0$ & 0 & $\$ 0$ & $\$ 0$ & $\$ 99,722$ & - \\
\hline 14 & Install conductivity controllers & 9 & $29,318,668$ & $\$ 38,701$ & 0 & $\$ 0$ & $\$ 38,701$ & $\$ 108,731$ & 2.81 \\
\hline 15 & $\begin{array}{l}\text { Install side-stream filtration or hydrodynamic } \\
\text { cavitation systems }\end{array}$ & 9 & $42,645,335$ & $\$ 56,292$ & $9,250,645$ & $\$ 145,956$ & $\$ 202,248$ & $\$ 2,672,667$ & 13.21 \\
\hline
\end{tabular}

\subsection{Space Cooling}

Space cooling is achieved at Y-12 via numerous refrigeration methods. Chiller systems, once-through water-cooled systems, as well as air-to-air direct expansion (DX) units, provide cooling to the more than 5 million square foot of building space at the site. DX systems require no water input, and therefore were not investigated during this assessment. Chiller systems and once-through water-cooled systems were evaluated as a part of this water assessment. Table 5.18 provides a cost/savings summary for the recommended space cooling improvements.

Table 5.18. Space Cooling Cost and Savings Summary

\begin{tabular}{|c|c|c|c|c|c|c|c|c|c|}
\hline WCM \# & WCM Description & Est. Count & $\begin{array}{c}\text { Est. Total } \\
\text { Water / Sewer } \\
\text { Savings } \\
\text { (gal/yr) }\end{array}$ & $\begin{array}{l}\text { Est. Total } \\
\text { Water / } \\
\text { Sewer } \\
\text { Savings } \\
\text { (\$\$ } \$ \mathbf{y r}) \\
\end{array}$ & $\begin{array}{c}\text { Est. Total } \\
\text { Energy } \\
\text { Savings } \\
\text { (kbtu/yr) }\end{array}$ & $\begin{array}{c}\text { Est. Total } \\
\text { Energy } \\
\text { Savings } \\
\text { (\$\$/yr) } \\
\end{array}$ & $\begin{array}{c}\text { Est. Total } \\
\text { Annual } \\
\text { Savings } \\
(\$ \$ \text { yr) } \\
\end{array}$ & $\begin{array}{c}\text { Est. Total } \\
\text { Installed Cost } \\
\text { (\$\$) }\end{array}$ & $\begin{array}{c}\text { Overall } \\
\text { Simple } \\
\text { Payback } \\
\text { (yrs) }\end{array}$ \\
\hline 16 & $\begin{array}{l}\text { Replace existing water-cooled air } \\
\text { conditioning system with air-cooled } \\
\text { equivalents }\end{array}$ & 45 & $23,220,432$ & $\$ 30,651$ & $(18,184,464)$ & $(\$ 286,913)$ & $(\$ 256,262)$ & $\$ 2,892,857$ & $\begin{array}{l}\text { not cost } \\
\text { effective }\end{array}$ \\
\hline & Space Cooling Upgrades TOTAL & & $23,220,432$ & $\$ 30,651$ & $(18,184,464)$ & $(\$ 286,913)$ & $(\$ 256,262)$ & $\$ 2,892,857$ & $\begin{array}{l}\text { not cost } \\
\text { effective }\end{array}$ \\
\hline
\end{tabular}

\section{Technical Approach and Calculation Methodology}

Chilled water loop systems use no water during the cooling process. The heat exchange fluid (either water, brine, or glycol) is recycled from chiller to heat exchangers in air-handling units.

The once-through water-cooled air conditioning systems that are present at Y-12 have a variety of different flow rates, based on the specific size of the unit. For the purposes of this assessment, an average of $2.3 \mathrm{gpm}$ constant flow rate was applied to each of the units. This flow rate was determined to be the average of spot metering tests conducted onsite.

\subsubsection{Chiller Systems}

Chiller systems provide the vast majority of space cooling at the Y-12 National Security Complex. A chiller system uses water, brine, or a glycol mix as a source of heat transfer through air-handling units. Chilled water systems are closed-loop systems and little to no make-up water is required. Water consumed through these systems actually occurs at the cooling tower, which is discussed in the previous section of this assessment. 


\subsubsection{Once-through Systems}

\section{Equipment Summary}

A few of the buildings included in the assessment scope of work contained older once-through, water-cooled air conditioning systems. These systems operate by passing potable water directly through airhandling units, much in the same way that DX air conditioning units use refrigerant. However, for the once-through systems at Y-12, the heat exchange fluid is not recycled, but rather passed through the exchangers once, then sent to a dechlorination plant and discharged to the storm drainage system.

\section{Existing Conditions}

The systems were found in various sizes and models throughout the complex. The majority of the water-cooled air conditioning units were found in the 9201-3 building, as shown in Figure 5.15, but other systems do exist located throughout the Y-12 Complex.

It is estimated that the Y-12 Complex contains approximately 45 of these types of air conditioning systems in total. Although the average flow rate varies from each individual unit, a statistical average of $2.3 \mathrm{gpm}$ can be used to determine the estimated annual water consumption from these units. Cooling days for the region must be taken into consideration, since water does not flow $100 \%$ of the time.

\section{Proposed Recommendations}

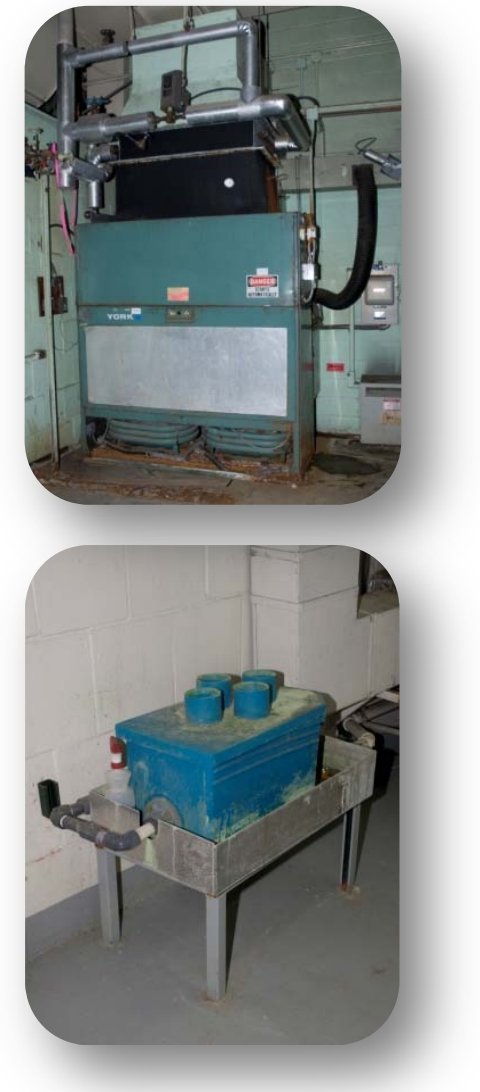

Figure 5.15. Typical Water-Cooled Air Conditioning Unit and Dechlorination Box

In order to reduce water consumption in this category, full removal of the existing oncethrough air conditioning systems must occur. However, operation costs of the existing systems are minimal compared to comparable DX or chiller systems. If the primary goal is to reduce water consumption, the existing systems can be replaced with comparable non-water using air conditioning systems (either DX or package chiller units). The reduction of water consumption does come at a cost of increased electrical energy. In fact, replacements of this kind would incur higher overall operating costs, and should be considered only as a way to further reduce facility water consumption, not overall utility budgets. Table 5.19 provides a cost/savings summary for the recommended improvements. 
Table 5.19. Space Cooling Upgrades Cost and Savings Detail

\begin{tabular}{|c|c|c|c|c|c|c|c|c|c|}
\hline WCM \# & WCM Description & Est. Count & $\begin{array}{c}\text { Est. Total } \\
\text { Water / Sewer } \\
\text { Savings } \\
\text { (gal/yr) }\end{array}$ & $\begin{array}{l}\text { Est. Total } \\
\text { Water / } \\
\text { Sewer } \\
\text { Savings } \\
\text { (\$\$yr) }\end{array}$ & $\begin{array}{l}\text { Est. Total } \\
\text { Energy } \\
\text { Savings } \\
\text { (kbtu/yr) }\end{array}$ & $\begin{array}{l}\text { Est. Total } \\
\text { Energy } \\
\text { Savings } \\
\text { (\$\$/yr) }\end{array}$ & $\begin{array}{l}\text { Est. Total } \\
\text { Annual } \\
\text { Savings } \\
\text { (\$\$/yr) }\end{array}$ & $\begin{array}{l}\text { Est. Total } \\
\text { Installed Cost } \\
\text { (\$\$) }\end{array}$ & $\begin{array}{c}\text { Overall } \\
\text { Simple } \\
\text { Payback } \\
\text { (yrs) }\end{array}$ \\
\hline 16 & $\begin{array}{l}\text { Replace existing water-cooled air } \\
\text { conditioning system with air-cooled } \\
\text { equivalents }\end{array}$ & 45 & $23,220,432$ & $\$ 30,651$ & $(18,184,464)$ & $(\$ 286,913)$ & $(\$ 256,262)$ & $\$ 2,892,857$ & $\begin{array}{l}\text { not cost } \\
\text { effective }\end{array}$ \\
\hline
\end{tabular}

\subsection{Steam Plant}

\section{Equipment Summary}

As of March 2010, the Y-12 Complex brought a new natural-gas-fired steam boiler plant online. The system is designed at maximum capacity of 240 thousand pounds per hour (Mlbs/hr) from three identical $80 \mathrm{Mlbs} / \mathrm{hr}$ boilers, plus an additional $80 \mathrm{Mlbs} / \mathrm{hr}$ boiler brought online in peak demand season or emergency back-up only. Traditionally, boiler plants will experience a higher demand during normal business hours (while facilities are occupied). However, due to the nature of operations and processes occurring at Y-12, steam demand only fluctuates with seasonal changes, and remains constant over the course of 24 hours.

Data supplied by Y-12 steam plant personnel indicated a peak load of $292 \mathrm{Mlbs} / \mathrm{hr}$ in January and a minimum load of $58 \mathrm{Mlbs} / \mathrm{hr}$ in June. The seasonal steam demand range is typical for the Oak Ridge, Tennessee, climate and the Y-12 facility that is primarily heated via steam heat exchange.

The Y-12 steam plant consumes water in three distinct ways. First, potable water is purified through a double-pass, partially recirculating reverse osmosis (RO) system, which generates purified product water and high mineral content reject water. Second, the product (also called "permeate") water from the RO system is fed to the main boilers and eventually becomes steam to be distributed through the Y-12 site. Third, the steam boilers run a constant blow-down in order to prevent fouling and scaling of the internal boiler compartments. Each of these system components is discussed in detail below. Table 5.20 provides a cost/savings summary for the recommended steam plant improvements.

Table 5.20. Steam Plant Upgrades Cost and Savings Summary

\begin{tabular}{|c|c|c|c|c|c|c|c|c|c|}
\hline WCM \# & WCM Description & Est. Count & $\begin{array}{c}\text { Est. Total } \\
\text { Water / Sewer } \\
\text { Savings } \\
\text { (gal/yr) }\end{array}$ & $\begin{array}{c}\text { Est. Total } \\
\text { Water / } \\
\text { Sewer } \\
\text { Savings } \\
\text { (\$\$\$Yyr) }\end{array}$ & $\begin{array}{l}\text { Est. Total } \\
\text { Energy } \\
\text { Savings } \\
\text { (kbtu/yr) }\end{array}$ & $\begin{array}{c}\text { Est. Total } \\
\text { Energy } \\
\text { Savings } \\
\text { (\$\$/yr) }\end{array}$ & $\begin{array}{c}\text { Est. Total } \\
\text { Annual } \\
\text { Savings } \\
\text { (\$\$/yr) }\end{array}$ & $\begin{array}{c}\text { Est. Total } \\
\text { Installed Cost } \\
\text { (\$\$) }\end{array}$ & $\begin{array}{c}\text { Overall } \\
\text { Simple } \\
\text { Payback } \\
\text { (yrs) }\end{array}$ \\
\hline & Steam Plant Upgrades TOTAL & & $48,484,848$ & $\$ 64,000$ & $44,468,745$ & $\$ 256,000$ & $\$ 320,000$ & $\$ 4,544,898$ & 14.20 \\
\hline
\end{tabular}




\section{Technical Approach and Calculation Methodology}

Steam plant details regarding production, blow-down, and reject-water flow rates were obtained onsite. A seasonal load curve was established based on historical data provided by steam plant personnel. Average monthly flow rates (based on system load) were used to determine production and reject flow rates. Boiler blow-down flow rate is constant throughout the year.

\section{Existing Conditions}

$\underline{\text { Steam Plant Reverse Osmosis Systems }}$

The steam plant RO system is a double-pass, partially recirculating filtration system. Potable water first supplied to the system is treated with $\mathrm{pH}$ balancing chemicals before being sent to the primary carbon filter/softener. The pre-filtered water is then passed through the Stage 1 RO micron filters, which reduces the total dissolved solids (TDS) levels from 310 parts per million (ppm) (potable tap water measurement) to approximately $64 \mathrm{ppm}$. The purified water continues downstream, while the reject water is partially recirculated for a second pass through the Stage 1 RO filters, and (currently) partially discharged to the sanitary sewer system. Drainage for the RO system is dual piped and has the potential to be discharged into the storm drainage system, once the Environmental group at Y-12 has cleared the reject water for storm discharge.

The product water from Stage $1 \mathrm{RO}$ filters is fed into Stage $2 \mathrm{RO}$ micron filters, where TDS levels are brought from $64 \mathrm{ppm}$ down to $38 \mathrm{ppm}$. The ultra purified product water of Stage 2 is fed directly to the steam boilers for steam production. The reject water generated at this stage is actually purer than potable water, so it is nearly $100 \%$ recirculated to the Stage 1 filters. Minimal reject flow rate was observed at the discharge point of Stage 2.

Overall, the steam plant RO system produces an average of $289 \mathrm{gpm}$ of ultra pure product water, while only rejecting an average of $82 \mathrm{gpm}$. The production rates of the RO system fluctuate based on steam plant demand, but the system always operates at a 78\% product water ratio, which is extremely efficient for RO filtration systems. No recommendations can be made at this time to improve the operating efficiency of the steam plant RO system.

\section{Boiler Blow-down}

As steam is produced, the remaining particulate in the purified water is released and can be deposited onto the internal walls of the boiler compartments and into the water basin of the boiler. As the mineral deposits collect, the boiler is prone to scaling. A constant blow-down in which the water basin is drained helps to minimize mineral levels and therefore prevent scaling and fouling of the internal boiler compartments and steam distribution lines. The blow-down rate has been engineered at a fixed $16 \mathrm{gpm}$. 


\section{$\underline{\text { Steam Production /System Losses }}$}

The final consumption of water in the steam plant is actually steam production itself. As previously stated, the steam plant will produce up to $292 \mathrm{Mlbs} / \mathrm{hr}$. A typical annual distribution was used to determine the total consumption of water that is distributed throughout the Y-12 Complex in the form of steam. As the steam is distributed throughout the site, there is steam lost through leaks, pressure relief valves, and steam traps. Although steam energy could be salvaged by repairing all of the distribution leaks, the water and energy savings does not justify the high cost of such repairs.

Currently, the steam condensate that is produced at the end-use point throughout Y-12 is not returned to the steam plant through a condensate return system. An energy savings performance contract (ESPC) is underway, however, that includes a condensate return system that will begin to bring a significant portion of the condensate back to the plant. Essentially, steam condensate is completely purified water, with the exception of any particulate and/or mineral content that is picked up from the end-use point or the return lines. The condensate can then be fed back into the RO filtration system, in order to be used again by the boilers. This condensate return system can significantly impact steam plant water consumption once fully operational. Additionally, condensate returns significant heat energy, thereby reducing consumption of natural gas to generate the same amount of steam.

\section{Proposed Recommendations}

Installation of steam plant sub-metering is recommended in order to accurately track water consumption. Currently, there are two separate potable water supplies that enter the steam plant facility. The two supplies eventually come together to form a large single supply for the RO systems. Meter installation is recommended after this junction, so that all water entering the RO systems, and eventually the steam boilers, can be monitored in real time. This location of metering system will not include any potable water used for domestic plumbing, as this water use is split off from one of the supplies prior to the junction. The domestic usage is insignificant at this building since it accounts for less than $1 \%$ of the building use.

Extension of the condensate recovery system into additional buildings that are not currently included in the ESPC contract can produce significant water and energy savings. It is recommended that this project be continued and expanded as possible for the Y-12 Complex. For the purposes of this assessment, the current condensate recovery project included in the ESPC project has been duplicated for budgetary cost and savings estimates. Table 5.21 provides a cost/savings summary for the recommended steam plant improvements. 
Table 5.21. Steam Plant Upgrades Cost and Savings Detail

\begin{tabular}{|c|c|c|c|c|c|c|c|c|c|}
\hline WCM \# & WCM Description & Est. Count & $\begin{array}{l}\text { Est. Total } \\
\text { Water / Sewer } \\
\text { Savings } \\
\text { (gal/yr) }\end{array}$ & $\begin{array}{c}\text { Est. Total } \\
\text { Water / } \\
\text { Sewer } \\
\text { Savings } \\
\text { (\$\$ /yr) }\end{array}$ & $\begin{array}{l}\text { Est. Total } \\
\text { Energy } \\
\text { Savings } \\
\text { (kbtu/yr) }\end{array}$ & $\begin{array}{l}\text { Est. Total } \\
\text { Energy } \\
\text { Savings } \\
\text { (\$\$/yr) }\end{array}$ & $\begin{array}{l}\text { Est. Total } \\
\text { Annual } \\
\text { Savings } \\
\text { (\$\$/yr) }\end{array}$ & $\begin{array}{l}\text { Est. Total } \\
\text { Installed Cost } \\
\text { (\$\$) }\end{array}$ & $\begin{array}{l}\text { Overall } \\
\text { Simple } \\
\text { Payback } \\
\text { (yrs) }\end{array}$ \\
\hline 17 & Install advanced sub-metering systems & 1 & 0 & $\$ 0$ & 0 & $\$ 0$ & \$0 & $\$ 44,898$ & - \\
\hline 18 & $\begin{array}{l}\text { Extend condensate recovery project to } \\
\text { include additional end use capture sites for } \\
\text { condensate return }\end{array}$ & - & $48,484,848$ & $\$ 64,000$ & $44,468,745$ & $\$ 256,000$ & $\$ 320,000$ & $\$ 4,500,000$ & 14.06 \\
\hline
\end{tabular}

\subsection{Demineralized Water}

Demineralized water is produced through a series of processes designed to remove all mineral and gas content that is dissolved in water. There are many methods for achieving this, though the most energy efficient is by passing water through a reverse osmosis and electrodeionizer system (RO/EDI). The RO/EDI processes reject a portion of the water that contains the stripped minerals and gases, while producing purified demineralized product water. High efficiency systems can generally produce $60 \%$ or higher product water, while only rejecting $40 \%$ or lower. The efficiency is improved by incorporation of a partial recycle system that allows reject water to pass through RO filters a second time. The result is higher mineral concentration in the final reject that is discharged to drain, but less water is consumed in the process overall.

\section{Technical Approach and Calculation Methodology}

Designed flow rates at each supply and discharge point were obtained in order to balance system inflows and outflows. Interviews with the demineralization plant staff indicated a constant runtime of the system. Calculations of baseline consumption were obtained by taking water supply flow rates (gpm) multiplied by 60 minutes per hour, 24 hours per day, 365 days per year, as indicated by plant operations staff.

\subsubsection{Current System}

\section{Equipment Summary}

The current demineralization plant did not consume any direct potable water. Instead, the existing system was fed steam condensate that is returned from various Y-12 plant processes. Condensate is typically very pure water containing only debris and dust particles that are picked up from the condensate return lines. These particles do however need to be removed. This is achieved first by sending the recovered condensate through activated carbon (charcoal) filters, and on to rented portable reverse osmosis (RO) units. From the carbon filters, the water is passed through mixed bed de-ionizers that strip the water of any minerals in solution, and on to a degasifier that removes any dissolved gases. This degasifier is a large energy consumer, due to the large steam venturi system used to generate the vacuum that removes dissolved gases. 
In the past, since no direct potable water is supplied to the demineralization plant, no baseline consumption could be attributed. All water supplied to this plant is essentially a by-product of steam plant production. However, as a result of the ESPC condensate recovery project, the condensate supply to this facility has been eliminated, and potable water must now serve as the water source to this plant process.

\section{Proposed Recommendations}

No recommendations can be made at this time. The current system is already scheduled for decommissioning once the new plant is brought online.

\subsubsection{Future System}

\section{Equipment Summary}

The future demineralization plant that is included in the ESPC that is currently underway, will eliminate the high energy use of the steam venturi at the cost of higher water consumption. The demineralization process for the new system is achieved by supplying potable water to the plant, where it is chemically treated, and passed through preliminary charcoal filters to remove sediment, on to a double chain of reverse osmosis/electronic de-ionization (RO/EDI) equipment. After passing through the system, the product water is then stored in large nitrogen-capped tanks that prolong usefulness of purified water. Since stagnation of purified water reduces the electrical resistance, the system is also equipped with a recirculation pump that allows purified water to circulate within the system itself until needed.

Waste water is produced during both the RO component and the EDI component of each equipment chain, in the form of reject water. Essentially, the reject water carries the removed minerals and ions (that have been taken out of solution) away from the purified water, and discharges to drain. Reject flow rates for the RO portion are designed to operate at $17.0 \mathrm{gpm}$, while the EDI reject is only $3.3 \mathrm{gpm}$.

In addition to reject water, both the RO and EDI components use a backwash to periodically flush the system for maintenance. The backwash is discharged to the sanitary sewer as well, due to its high mineral content. The backwash flow rates for the RO portion are designed at $2.2 \mathrm{gpm}$, and EDI backwash flow rate is designed at $1.7 \mathrm{gpm}$.

The system generates $45.0 \mathrm{gpm}$ per equipment chain, for a total of $90.0 \mathrm{gpm}$, or $47,336 \mathrm{kgal}$ annually. The system has a combined reject/backwash rate from all sources and both equipment chains of $48.2 \mathrm{gpm}$, or $25,456 \mathrm{kgal}$ annually.

\section{Proposed Recommendations}

No recommendations can be made at this time. While the new system will use more water than the current system, due to removal of steam condensate serving as the supply water, it does indeed use far less energy. The system is designed as efficiently as possible by incorporating 
partial recirculation and pre-filtering. This allows for a $65 \%$ production:35\% rejection ratio. Efficient systems of this nature are classified as having a 60\%:40\% ratio or better.

\subsection{Irrigation}

The only formal irrigation systems identified at the Y-12 Complex are located at the JCC. The system is a typical timer-based controller with a mixture of pop-up sprayer and rotor-type nozzles. This particular system is not an advanced "intelligent" control system that uses evapotranspiration weather data to apply the appropriate amount of supplemental precipitation to the landscapes. However, interviews with the JCC staff indicated that the system is generally kept offline, except for periods of drought. Water consumption due to irrigation onsite is minimal, and upgrading to an "intelligent" weather-based system would actually increase the water consumption, since the irrigation system is mainly off-line. For this reason, no recommendations for irrigation improvements can be made at this time.

\subsection{Miscellaneous and Unaccounted}

Miscellaneous water consumption encompasses all categories of use that are not included in the systems mentioned above. Some examples of miscellaneous usage include drinking fountains, coffeemakers, personal water consumption (e.g., plate washing, drinking), janitorial use, and various other tasks. Often this category is used as a buffer region for water balancing, to allow for conservative calculations of use and savings potential. Tight water balances will generally assign $20 \%$ or less to the miscellaneous and unaccounted usage category. For Y-12, the water-assessment team has completed a water balance that leaves only $16.3 \%$ for this category.

\subsection{Losses}

Various system losses occur in any water distribution system in the form of leaks, overflow, or damaged equipment. A statistical average of $2 \%$ leakage is exhibited on complete municipal/regional water distribution systems. The amount of leakage increases with the age of systems as infrastructure begins to deteriorate or degrade over time. The same is true for localized distribution systems, such as that of the Y-12 Complex. The majority of the complex's water distribution system dates back to the 1940s, so a liberal estimation of $4 \%$ leakage was used in preparation of the water balance. The majority of this leakage will come in the form of pinhole leaks in the site distribution, leaky faucets, and various other sources. These leaks are virtually invisible, since the volume of water lost is in small amounts and distributed throughout the 28 miles of distribution lines present on the site.

\subsection{Operations and Maintenance Recommendations}

Observations of operations and maintenance (O\&M) practices onsite indicated a general practice of reactive maintenance, where equipment is repaired when a problem occurs. This type of maintenance is unavoidable, but should be supplemented with preventative maintenance 
programs designed to improve both water and energy efficiency, extend the useful life of equipment, and provide preliminary warning of system deficiencies or failure.

\section{Total Accountability and Management Plan (TAMP)}

The single most effective preventative maintenance plan as it applies to water efficiency is implementation of a Total Accountability and Management Plan (TAMP). A TAMP is based on attempting to account for every gallon entering and exiting the facility. This type of program begins, at the very least, with installation of water sub-meters at the building level. At a minimum, the water-sub-meters should be read monthly to coincide with master meter read dates. Advanced systems, using the site's intranet, can provide minute-by-minute real-time readings that can allow for easy tracking, charting, and analysis of building consumption. The optimal benchmark is the sum of sub-meter readings equaling the sum of master-meter readings, though this is seldom perfectly achieved due to accuracy differentials in different meter types. Substantial variations between master meter data and sub-meter data requires investigation and reconciliation.

As data is archived, consumption trends can be identified and subsequent building performance can be measured against "real” historical data. This tool allows site water managers to discover sudden increases in water use, hidden leaks, and previously unknown uses. Advancing the system further includes installation of sub-meters on all major water-using equipment inside the buildings, in order to create sub-categories of usage within a building. This advancement aids in reconciliation of discrepancies and assists in pinpointing excessive use areas.

Sub-metering costs vary greatly based on location, type, and size of meter required. As an estimate, buildings requiring an external meter pit would incur installation costs of roughly $\$ 40,000$ each, whereas internal building water supply lines that provide enough space to cut in a sub-meter can incur implementation costs as low as $\$ 15,000$. These estimated costs fluctuate with the supply line size. Storage and other ancillary buildings that do not have plumbing can be excluded from the TAMP program.

\section{Water Conservation Awareness Program (WCAP)}

Conservation awareness can provide a significant impact to water consumption reduction goals. A WCAP involves engaging the site population to discuss water efficiency, reduction goals for the site, and ways to reduce water consumption. The general steps for incorporating a WCAP are as follows:

1. Establish a plan with specific goals and encourage all employees to do their part. Post signs throughout the facilities designed to raise awareness of water consumption among Y-12 staff. Include water conservation policies and procedures in staff training programs. The web portals at Y-12 provide an excellent opportunity for site-wide training. Statistically, once employees start thinking about their water use, water consumption decreases. 
2. Get creative by using visual tools such as charts and graphs to highlight water savings. Use communications such as newsletters, bulletins, and emails to send staff water savings tips, announcements, and progress reports.

3. Encourage notification of system failures and deficiencies by setting up incentive programs. Conduct contests for employees regarding water efficiency and conservation techniques.

Water conservation awareness is an ongoing effort, so it is recommended to place one person in charge of the WCAP, so that knowledge regarding water conservation remains in the forefront of Y-12's mission. Continual growth and involvement of the WCAP in everyday Y-12 life is crucial to the ongoing success of a water conservation program.

\section{Annual Inspections Program (AIP)}

The AIP is designed to provide routine checks on all water-using equipment. Conditions of equipment should be noted and any found to be deficient should be discussed in executive staff meetings. Awareness of existing system condition can provide information for effective budgetary planning for system repair and replacement. This type of program will not only reduce water and energy consumption of equipment, but will help to prolong the life of equipment, reducing capital improvement costs over the long haul.

The AIP should include, but not be limited to, the following systems:

1. Domestic plumbing fixture inspections - Visually inspect all toilets and urinals to make sure valves operate properly, proper evacuation of trapways occur, and valve components and fittings are free of leaks. Visually inspect faucets to ensure valves close properly and faucets and faucet supply lines are free of drips/leaks. Visually inspect showerheads and shower supply valves to ensure proper shutoff and absence of shower leaks. Faucet restrictors and showerheads are also recommended to be soaked in a lime and mineral removing substance annually so that any debris that becomes lodged in the restriction areas is dissolved. This will improve fixture performance, but not necessarily reduce consumption.

2. Steam trap and distribution system inspections - All steam traps should be inspected annually. Any that have failed should be immediately replaced in order to reduce both water and energy consumption. Steam distribution lines should be inspected annually to identify pipe leaks and other system losses. Any system leaks should be repaired immediately.

3. Process heat exchanger inspections - All process heat exchangers (whether chilled loop, condenser loop, or single pass) should be inspected annually for deficiency. Inlet and outlet temperature readings should be taken to determine heat exchange effectiveness. End customers should be held accountable for equipment that is in disrepair, or exhibits a temperature differential of less than 7 degrees while in operation.

4. Cooling tower maintenance - Since cooling tower consumption is one of the largest categorical uses at Y-12, maintenance and inspections of these systems should occur monthly. Monthly configuration of conductivity controllers and cleaning of filtration 
systems is a must. Cooling tower basins should be drained annually and swept clean of any sludge or mineral deposits. While basins are drained, they should be inspected for any cracks or signs of leakage and patched immediately.

5. Potable water distribution system leak survey - Leak detection companies can be utilized to conduct leak surveys of the potable water distribution systems. Leaks that are identified should be prioritized for repair from largest to smallest. Leak surveys are recommended once every four years, though for Y-12, a $25 \%$ inspection annually is recommended. 


\section{Appendix A}

\section{Assessment Methodology}

\section{A.1 Detailed Calculation Methodologies}

\section{A.1.1 Domestic Plumbing Fixture Consumption}

Pre/Post Fixture Consumption = FUPD (fixture usage per day) X DPYO (days per year occupied) X Pre/Post Flow-rate

Fixture usage per day (FUPD) is determined by the following parameters:

- Population and Occupancy data is obtained onsite (through interviews and information provided by facility personnel)

- A 50\%/50\% split of male vs. female population was used throughout all calculations, because no specific demographic information was available.

- Males will use urinals $75 \%$ of time if available.

- Industry standard assumptions were used in all calculations: Each person will use a toilet or urinal once per 2 hours, lavatory faucets will be used an average of 6 seconds ( $0.1 \mathrm{~min})$ per flush, kitchen/lab faucets (when used) flow for a total time of 2 minutes in a non-residential setting, and showers (when used) flow for 8 minutes in a non-residential setting.

- A Flush or Usage Factor percentage is also used in order to scale usage up or down based on matching modeled consumption to sub-meter data. If no sub-meter data, these factors typically remain at $100 \%$ unless facility specific reasons indicate differently, i.e., shower only used by one person, once in a while.

- Female toilet usage per day (FTUPD) = Female population X hours per day occupied X 1 flush per 2 hours X flush factor

- Male toilet usage per day (MTUPD) = Male population X hours per day occupied X 1 flush per 2 hours X flush factor X 25\%

- Male urinal usage per day (MUUPD) = Male population X hours per day occupied X 1 flush per 2 hours X flush factor X 75\%

- Lavatory usage per day (LUPD) = (FTUPD + MTUPD + MUUPD) X 6 seconds X 1 minute per 60 seconds X lavatory usage factor

- Kitchen/Lab Faucet usage per day (KUPD) = Total Population X 2 minutes per day X kit/lab usage factor 
Note: kit/lab usage factor is often $10 \%$ or less

- Shower usage per day (SUPD) = Total Population X 8 minutes per day X shower usage factor

All thermal water heating savings calculations use the following formula:

- Lavatory faucets are assumed to utilize 25\% hot water, kitchen/laboratory faucets are assumed to use 50\% hot water, and showers are assumed to use $80 \%$ hot water.

- Total Hot Water Saved = Total Water Saved X \% of water that is heated

- Thermal Energy Savings (Btu/yr) = Total Hot Water Saved (gal/yr) X Volume Conversion (8.33 lbs per gal) X C (specific heat of water, $0.999 \mathrm{Btu} / \mathrm{lb}-{ }^{0} \mathrm{~F}$ ) X $\Delta$ )

- Total Fuel Savings (fuel unit/yr) = Thermal Energy Savings (Btu/yr) / Fuel Rating (Btu/fuel unit) / Efficiency of system

- Total Energy Cost Savings $(\$ \$ / y r)=$ Total Fuel Savings (fuel unit/yr) X Fuel Cost (\$\$/fuel unit)

\section{A.1.2 Kitchen Equipment Consumption}

Current / Future Equipment Consumption = Equipment operation time (hours per day) $X 60$ minutes per hour X DPY (days per year) X current/future consumption rate

All thermal water heating savings calculations use the following formula:

- Total Hot Water Saved = Total Water Saved X \% of water that is heated

- Thermal Energy Savings (Btu/yr) = Total Hot Water Saved (gal/yr) X Volume Conversion (8.33 lbs per gal) X $\mathbf{C}$ (specific heat of water, $0.999 \mathrm{Btu} / \mathrm{lb}-{ }^{\circ} \mathrm{F}$ ) X $\Delta \mathbf{T}$

- Total Fuel Savings (fuel unit/yr) = Thermal Energy Savings (Btu/yr) / Fuel Rating (Btu/fuel unit) / Efficiency of system

- Total Energy Cost Savings $(\$ \$ / y r)=$ Total Fuel Savings (fuel unit/yr) X Fuel Cost (\$\$/fuel unit) 


\section{Appendix B}

\section{FY2007 Adjusted Baseline Methodology}

The original FY2007 potable water-use baseline submitted by the Y-12 Complex to DOE was 806.19 million gallons. This data was based on the metered data sent to Y-12 via water bills from the City of Oak Ridge. This annual water use was uncharacteristically low compared to previous years. (The FY2007 use was 43\% lower than the previous water use in FY2006.) It was discovered that the low water use was due to failed water meters. The Executive Orders 13423 and 13514 require that all Federal agencies reduce potable water by $2 \%$ each year based on a baseline in FY2007. Because Y-12's FY2007 baseline is incorrect due to the failed meters, it is imperative that a new baseline is developed that best represents the actual water use of FY2007 so that water reductions can be accurately tracked.

To correct this problem, an adjusted FY2007 potable water-use baseline was estimated by examining the trends in the annual water use prior to the meters failing and after the meters were replaced. First the data was analyzed for any anomalies. It was discovered that during FY2006, water use in November, December, January, and February was unusually high. The water use during this same time period (November through February) for previous years was between 26\% and $40 \%$ lower. Because of this unusual spike in water use in FY2006, these outlining data points were removed and replaced with average monthly values so that the FY2007 baseline would not be skewed upwardly.

After removing outliers in the data set, a linear extrapolation was developed for years before and subsequent to the meter replacements. Meters were replaced in early FY2009. In Figure B.1, two linear regressions are shown for the years before and after the meter replacement. The extrapolated data for FY2007 is shown for each linear regression. The bi-sect between the two extrapolated linear regressions is the estimated water use for FY2007. The original reported FY2007 baseline is also shown in the chart, which is far below this new adjusted baseline. Based on the extrapolation, the new FY2007 baseline is estimated to be 1,370 million gallons. 


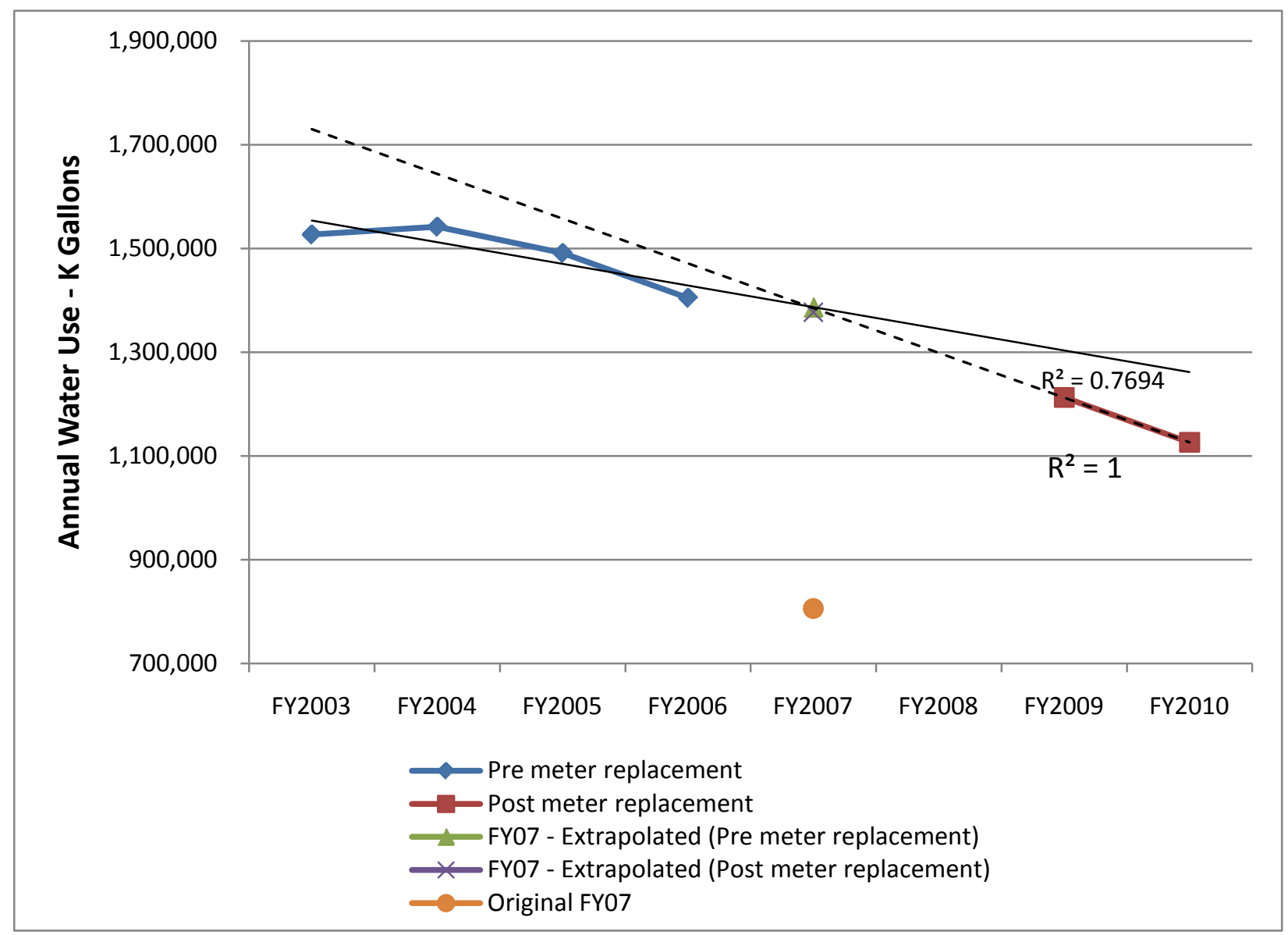

Figure B.1. Linear Extrapolation of Historic Potable Water Use 


\section{Appendix C}

\section{Sample Water Audit Checklists}

The following tables provide the water audit checklists that were used during the Y-12 water assessment. The checklists cover the following equipment and processes:

- Domestic Plumbing - toilets, urinals, faucets, and showerheads

- Once-through Cooling

- Process Equipment

- Other Water-Consuming Equipment - ice machines, reverse osmosis, and sterilizers and autoclaves

These forms were filled out by Y-12 staff to assess water use of processes and equipment in secure buildings that were inaccessible by the water assessment team. These may be a good starting place for water audits at other DOE sites. 


\section{Y-12 Building Information Checklist for Water Assessment}

\begin{tabular}{|c|c|c|c|c|}
\hline \multicolumn{5}{|c|}{ Domestic Plumbing } \\
\hline \multicolumn{5}{|c|}{ Building Number: } \\
\hline \multicolumn{5}{|l|}{ Toilets } \\
\hline Quantity & Type & $\begin{array}{l}\text { Low Flow / } \\
\text { High Flow? }\end{array}$ & Specification / Notes & $\begin{array}{c}\text { Sample } \\
\text { Pics }\end{array}$ \\
\hline \multicolumn{5}{|l|}{ Urinals } \\
\hline Quantity & Type & $\begin{array}{l}\text { Low Flow / } \\
\text { High Flow? }\end{array}$ & Specification / Notes & $\begin{array}{c}\text { Sample } \\
\text { Pics }\end{array}$ \\
\hline \multicolumn{5}{|c|}{ Lavatory Faucets } \\
\hline Quantity & & $\begin{array}{l}\text { Low Flow/ } \\
\text { High Flow? }\end{array}$ & Specification / Notes & $\begin{array}{c}\text { Sample } \\
\text { Pics }\end{array}$ \\
\hline \multicolumn{5}{|c|}{ Kitchen / Break Room Faucets } \\
\hline Quantity & & $\begin{array}{l}\text { Low Flow / } \\
\text { High Flow? }\end{array}$ & Specification / Notes & $\begin{array}{c}\text { Sample } \\
\text { Pics }\end{array}$ \\
\hline \multicolumn{5}{|c|}{ Lab Faucets } \\
\hline Quantity & Type & $\begin{array}{l}\text { Low Flow / } \\
\text { High Flow? }\end{array}$ & Specification / Notes & $\begin{array}{c}\text { Sample } \\
\text { Pics }\end{array}$ \\
\hline \multicolumn{5}{|c|}{ Showerheads } \\
\hline Quantity & Type & $\begin{array}{l}\text { Low Flow / } \\
\text { High Flow? }\end{array}$ & Specification / Notes & $\begin{array}{c}\text { Sample } \\
\text { Pics }\end{array}$ \\
\hline & & & & \\
\hline & & & & \\
\hline
\end{tabular}


Y-12 Building Information Checklist for Water Assessment

\begin{tabular}{|c|c|c|c|c|c|c|}
\hline Once 1 & ough Spa & ling & & & & \\
\hline Buildir & Number: & & & & & \\
\hline Quantity & Manufacturer & Model \# & $\begin{array}{c}\text { Cooling } \\
\text { Capacity } \\
\text { (tons) } \\
\end{array}$ & $\begin{array}{c}\text { Water Supply } \\
\text { Line Size } \\
\text { (in. diameter) }\end{array}$ & $\begin{array}{c}\begin{array}{c}\text { Dischange } \\
\text { Piping }\end{array} \\
\end{array}$ & $\begin{array}{c}\text { Sample } \\
\text { Pics }\end{array}$ \\
\hline & & & & & & \\
\hline & & & & & & \\
\hline & & & & & & \\
\hline & & & & & & \\
\hline & & & & & & \\
\hline & & & & & & \\
\hline & & & & & & \\
\hline & & & & & & \\
\hline & & & & & & \\
\hline & & & & & & \\
\hline & & & & & & \\
\hline & & & & & & \\
\hline & & & & & & \\
\hline & & & & & & \\
\hline & & & & & & \\
\hline & & & & & & \\
\hline & & & & & & \\
\hline & & & & & & \\
\hline
\end{tabular}


Y-12 Building Information Checklist for Water Assessment

Process Cooling

Building Number:

\begin{tabular}{|c|c|c|c|c|c|}
\hline Process \# & $\begin{array}{l}\text { Runtime Average } \\
\text { (thrs/day) }\end{array}$ & $\begin{array}{l}\text { Operation Time } \\
\text { (days / vear) }\end{array}$ & $\begin{array}{c}\text { Water Supply } \\
\text { Line Size } \\
\text { (in. diameter) }\end{array}$ & $\begin{array}{l}\text { Water Supply } \\
\text { Type }\end{array}$ & Discharge Piping \\
\hline & & & & & \\
\hline & & & & & \\
\hline & & & & & \\
\hline & & & & & \\
\hline & & & & & \\
\hline & & & & & \\
\hline & & & & & \\
\hline & & & & & \\
\hline & & & & & \\
\hline & & & & & \\
\hline & & & & & \\
\hline & & & & & \\
\hline & & & & & \\
\hline & & & & & \\
\hline & & & & & \\
\hline & & & & & \\
\hline & & & & & \\
\hline & & & & & \\
\hline
\end{tabular}




\section{Y-12 Building Information Checklist for Water Assessment}

\section{Various Equipment}

\section{Building Number:}

\begin{tabular}{|l|l|l|l|l|l|}
\hline \multicolumn{2}{|c|}{ Manuf acturer } & Model \# & $\begin{array}{c}\text { Air / Water } \\
\text { Cooled? }\end{array}$ & $\begin{array}{c}\text { Avg. \% of Bin } \\
\text { Used Daily }\end{array}$ & $\begin{array}{c}\text { Sample } \\
\text { Pics }\end{array}$ \\
\hline Quantity & & & & & \\
\hline & & & & & \\
\hline & & & & & \\
\hline \\
\hline
\end{tabular}

\begin{tabular}{|l|l|l|l|l|}
\hline \multicolumn{2}{|c|}{ Sterilizers / Autoclaves } & Model \# & $\begin{array}{c}\text { Avg. \# of Cycles } \\
\text { per Week }\end{array}$ & $\begin{array}{c}\text { Sample } \\
\text { Pics }\end{array}$ \\
\hline Quantity & Manufacturer & & & \\
\hline & & & & \\
\hline & & & & \\
\hline & & & & \\
\hline
\end{tabular}




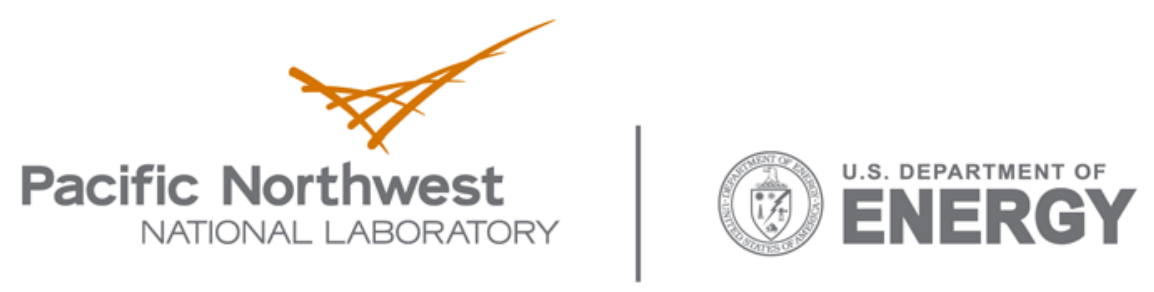

902 Battelle Boulevard

P.O. Box 999

Richland, WA 99352

1-888-375-PNNL (7665)

www.pnl.gov 